\title{
Una aproximación al estatus jurídico del lobo en la legislación española
}

\author{
José Alfredo Vidal Rettich \\ MA Derecho Animal y Sociedad (UAB) \\ ORCID: https://orcid.org/0000-0002-6081-6496
}

Recepción: Marzo 2021

Aceptación: Mayo 2021

Cita recomendada. VIDAL RETTICH, J.A., Una aproximación al estatus jurídico del lobo en la legislación española, dA. Derecho Animal (Forum of Animal LawStudies) 12/2 (2021). - DOI https://doi.org/10.5565/rev/da.570

\section{Resumen}

El estudio del estatus jurídico del lobo, atendiendo a la normativa comunitaria y al ordenamiento jurídico español, es una tarea básica para proteger la especie y asegurar su conservación. Contextualizar el tema desde otras vertientes, como la ecológica o la social, y entender la evolución histórica de la relación entre Canis lupus y Homo sapiens, ayuda a comprender la situación actual del problema. A la vez, posibilita la búsqueda de soluciones eficaces para solventar los problemas que pueden derivarse de la protección de la especie. La exposición crítica del ordenamiento jurídico actual es necesaria para explorar posibles vías que permitan una mayor eficacia en su conservación. Entre otros problemas, es obvio que las diferencias sustanciales en las normativas sobre la conservación y gestión del lobo establecidas por las Comunidades Autónomas, hacen inviable una protección efectiva. Por ello, debe exigirse a los poderes públicos unos criterios de actuación más adecuados para la conservación de esta especie.

Palabras clave: protección fauna silvestre; lobo (Canis lupus); conflicto; estatus jurídico; armonización legislativa; coexistencia; conservación.

\section{Abstract - An approach to the legal status of wolves in Spanish legislation}

Studying the legal status of wolves in accordance with community legislation and the Spanish legal framework is a fundamental task for protecting the species and ensuring its conservation. Contextualising the topic within other aspects, such as the ecological or social, and understanding the historical evolution of the relationship between canis lupus and homo sapiens helps to understand the current situation of the issue. At the same time it facilitates the search for effective solutions to resolve the problems that arise from protecting the species. A critical exposition of the legal framework is necessary for exploring possible routes that would allow more efficient conservation. Among other issues, it is obvious that the substantial differences between Autonomous Community regulations on the conservation and management of wolves renders effective protection unfeasible. For this reason, more adequate criteria for action for the conservation of this species must be demanded of public powers.

Keywords: wildlife protection; wolf (Canis lupus); conflict; legal status; legislative harmonization; coexistence; conservation. 


\section{Sumario}

Introducción

I. Lobo y sociedad

1. Breve aproximación histórica

2. Situación actual

II. Estatus jurídico del lobo en España

1. Legislación de la Unión Europea en materia de protección de la vida silvestre

2. El lobo en el ordenamiento jurídico español: normativa estatal y de las CCAA

3. Las divergencias normativas entre CCAA sobre la protección y la caza del lobo

III. Derecho y sociedad: un futuro para el lobo

1. Exposición crítica del actual estatus legal del lobo en el Derecho español

2. Coordinación de competencias legislativas como una posible solución para una protección adecuada de la especie

Conclusiones

\section{Abreviaturas}

$\begin{array}{ll}\text { ADENA } & \text { Asociación para la Defensa de la Naturaleza } \\ \text { AAPP } & \text { Administraciones Públicas } \\ \text { ASCEL } & \text { Asociación para la Conservación y Estudio del Lobo } \\ \text { BOE } & \text { Boletín Oficial del Estado } \\ \text { CC } & \text { Código Civil Español } \\ \text { CCAA } & \text { Comunidades Autónomas } \\ \text { CE } & \text { Constitución Española } \\ \text { CEA } & \text { Catálogo Español de Especies Amenazadas } \\ \text { CEE } & \text { Comunidad Económica Europea } \\ \text { CIEDA } & \text { Centro Internacional de Estudios de Derecho Ambiental } \\ \text { CITES } & \text { Convención sobre el Comercio Internacional de Especies Amenazadas de Fauna y Flora } \\ \text { Silvestres } & \\ \text { CP } & \text { Código Penal } \\ \text { FAPAS } & \text { Fondo para la Protección de los Animales Salvajes } \\ \text { LESPRE } & \text { Listado de Especies Silvestres en Régimen de Protección Especial } \\ \text { MITECO } & \text { Ministerio para la Transición Ecológica y el Reto Demográfico } \\ \text { OCDE } & \text { Organización para la Cooperación y el Desarrollo Económicos } \\ \text { ONG } & \text { Organización no gubernamental } \\ \text { ONU } & \text { Organización Naciones Unidas } \\ \text { PAC } & \text { Política Agraria Comunitaria } \\ \text { PACMA } & \text { Partido Animalista Contra el Maltrato Animal } \\ \text { RD } & \text { Real Decreto } \\ \text { TFUE } & \text { Tratado de Funcionamiento de la Unión Europea } \\ \text { TJUE } & \text { Tribunal de Justicia de la Unión Europea } \\ \text { TSJ } & \text { Tribunal Superior de Justicia } \\ \text { UE } & \text { Unión Europea } \\ \text { UICN } & \text { Unión Internacional para la Conservación de la Naturaleza } \\ \text { UNESCO } & \text { Organización de la Naciones Unidas para la Educación, la Ciencia y la Cultura } \\ \text { Vid. } & \text { Vide (Véase) } \\ \text { WWF } & \text { World Wildlife Found } \\ & \end{array}$




\section{Introducción}

Es una realidad que, bajo el paraguas de la preocupación por el medio ambiente, se ha llegado a un cierto grado de protección de la fauna silvestre. Un primer reconocimiento de la degradación del planeta por la acción humana fue la Declaración de la Conferencia de la ONU sobre el Medio Humano, celebrada en Oslo en 1972, que señalaba nuestro deber de proteger y mejorar el medio ambiente para las generaciones presentes y futuras ${ }^{1}$.El primer manifiesto sobre la necesidad de protección del lobo, a nivel global, fue en una conferencia internacional sobre la conservación del lobo, celebrada en Estocolmo, en septiembre de 1973. Reunió a expertos de diferentes países, bajo el patrocinio de la Unión Internacional para la Conservación de la Naturaleza, y redactó unas Directrices para la Conservación del Lobo, revisadas en años posteriores.

La Constitución española de 1978, en su artículo 45, recogió el derecho a disfrutar de un medio ambiente adecuado y el deber de conservarlo, pero no existe una referencia explícita en relación con la protección de los animales. Justo al año siguiente, en 1979, se celebraba el Convenio relativo a la conservación de la vida silvestre y del medio natural de Europa, en Berna, y aquí sí se reconocía explícitamente la fauna silvestre como patrimonio natural, así como la necesidad de preservarla para las generaciones futuras. Cierto es que, con el tiempo, el corpus jurídico referente a la fauna silvestre ha ido ampliándose, tanto en Europa como en España.

Nuestro trabajo versa sobre un animal silvestre parte del patrimonio natural europeo, el lobo, y pretendemos ofrecer una primera aproximación a su estatus jurídico en la legislación española. El lobo ibérico (Canis lupus signatus o Canis lupus Linnaeus, 1758), es una subespecie del lobo pardo europeo (Canis lupus lupus), cuya área de distribución era, hasta no hace mucho tiempo, toda la Península Ibérica. Actualmente, su población se encuentra delimitada a unos pocos territorios, especialmente en el noroeste peninsular.

Del título del trabajo se desprende, como es obvio, su contenido jurídico. Aún así, y atendiendo al carácter transversal de los conocimientos impartidos en el máster, creemos que puede enriquecerse con un planteamiento que contemple una perspectiva más amplia. Por esta razón, antes de abordar la materia propiamente jurídica, creemos conveniente contextualizar el tema objeto del trabajo, en un intento de ofrecer una visión global, en cierta medida interdisciplinar, para una mejor comprensión del contexto que envuelve la conservación de la especie.

En primer lugar, es imprescindible tratar sobre la relación entre esta especie y la humana, con la que lleva coexistiendo desde los orígenes de la Humanidad. En segundo lugar, en cuanto al contenido jurídico, se analiza la normativa sobre la fauna silvestre en la legislación de la Unión Europa y en el ordenamiento jurídico español, de aplicación al lobo. Por último, el estudio se completa con una exposición crítica de la situación del ordenamiento jurídico español en relación con esta especie.

Ante la naturaleza global del problema del derecho animal, especialistas de reconocido prestigio, como la Dra. Anne Peters, abogan por la necesidad de una regulación global o transnacional ${ }^{2}$.También el Dr. David Favre ha defendido la necesidad de un tratado internacional de bienestar animal, y que debería incluir la fauna salvaje y sus hábitats ${ }^{3}$. De manera análoga, nosotros defendemos la necesidad de una regulación normativa global e interterritorial para la preservación del lobo. Las diferencias sustanciales en su conservación y gestión, establecidas por las Comunidades Autónomas, hacen inviable una protección efectiva. De no hacerlo, la conservación del lobo estaría en serio peligro y, para muchos, podría llevar a la extinción de la especie.

La Dra. Giménez-Candela apunta la actitud de reserva o de silencio absoluto que el Derecho ha tenido, hasta hace poco, en relación a los animales: “...sólo ha habido esporádicas, aunque interesantes, incursiones en el mundo animal y debates auspiciados por las necesidades humanas, que siempre resultan más apremiantes, que la reflexión sobre la inserción de los animales en la vida social y en el sistema jurídico." Cuando nos referimos a los animales silvestres, la realidad puede ser aún más descarnada. Para casi todas las sociedades humanas, las especies salvajes no han gozado de compasión alguna. Es verdad que su caza ha sido necesaria en amplios períodos de la historia de la humanidad, así como complementaria en otros; actualmente, y para muchas sociedades, ha llegado a convertirse en un pasatiempo. Eso sí, siempre amparado bajo pretextos de tradición, cultura o supuesta necesidad económica o pretendido equilibrio ecológico.

Un eminente especialista sobre el tema, el Dr. Félix Rodríguez de la Fuente, en la citada conferencia internacional sobre la conservación del lobo, presentó una ponencia sobre la concienciación pública de la protección del lobo en España ${ }^{5}$. En ella exponía la necesidad de diversas medidas para la protección del lobo,

\footnotetext{
${ }^{1}$ Mulà Arribas, A., Derecho ambiental versus derecho animal, en Animales y Derecho (Animals and theLaw), (Valencia 2015) 330.

2 Peters, A., Global Animal Law: What it is and why we need it, en Transnational Envirommental Law, (Cambridge 2016), 9-23.

${ }^{3}$ Favre, D., An International Treaty for Animal Welfare, 18 Animal L. 237 (2012).

${ }^{4}$ Giménez-Candela, Marita, Transición animal en España, (Valencia 2020), 164.

${ }^{5}$ Rodríguez de la Fuente, F., Protection of the wolf in Spain. Notes on a public awareness campaign, en Proceedings of the First Working Meeting of Wolf Specialists and of the First International Conference on Conservation of the Wolf, (Estocolmo 1973), 103- 
entre la cuales, una adecuada y firme legislación para hacer efectiva esa protección. Aunque las acciones que se tomaron en su momento para mejorar la imagen del lobo y la necesidad de su conservación resultaran positivas para buena parte de la ciudadanía, se quejaba que un sector no abandonó su "vieja actitud anti-lobo". La respuesta de este grupo social fue agresiva: exigencias a la Administración Pública para la eliminación del lobo e incremento de la presión en los medios de comunicación en contra del lobo. Hasta se llegó a acusar al reconocido naturalista de soltar lobos en la naturaleza para que pudieran devorar ovejas.

Desde ese documento han pasado casi 50 años y, por desgracia, no se ha avanzado lo suficiente, repitiéndose constantemente actitudes del todo anacrónicas. Por ello, sostenemos que la protección del lobo en toda la Península Ibérica y el cese de la actividad cinegética sobre la especie son necesarios. Los poderes públicos y los agentes jurídicos, entre otros, deberían encaminar sus acciones a preservar el patrimonio natural que supone esta especie, desde unas exigencias más acordes con el espíritu de las leyes que recogen su conservación y la realidad en la que vivimos.

\section{Lobo y sociedad: estado de la cuestión}

Las cuestiones derivadas de la coexistencia entre la especie humana y los animales silvestres, sobre todo cuando estos son grandes carnívoros, tienden a ser complicadas. Utilizando el símil de una ecuación, los factores que configuran esa relación son múltiples; no obstante, dos son determinantes: el cultural y el económico. El estudio del estatus jurídico del lobo es por sí mismo relevante, pero no suficiente para percibir en toda su globalidad las interacciones que se establecen entre el lobo y la sociedad humana. La diversidad de agentes sociales y económicos involucrados hace imprescindible contextualizar el tema.

Y no podemos analizar el presente sin adentrarnos en el pasado. Estudiar las leyendas que sobre el lobo nutren la cultura popular seguramente daría para escribir una tesis; sin embargo, nuestra intención es mucho más concreta, y se centra en poner en tela de juicio la idea extendida de que el lobo ha sido siempre un elemento distorsionador del bienestar de los ganaderos. La historia, escrita y oral, es la que alimenta esa cultura popular, y no siempre se ciñe a la realidad, pecando de cierto subjetivismo.

Por esta razón, es de interés empezar con una breve incursión en el mundo rural, en su actividad ganadera a lo largo del tiempo, en sus relaciones con la sociedad y la economía de diferentes épocas de la historia. Y apuntar, en la medida de lo posible, algunas ideas distintas a las preconcebidas sobre la interacción del mundo rural y el lobo.

La idea básica es la de que el lobo no es el culpable de los problemas que aquejan a los ganaderos, sino más bien un chivo expiatorio. Puede causar algunos perjuicios, pero de ahí a culparlo de los problemas del sector, es del todo exagerado. Es más, en las áreas rurales donde el lobo ha desaparecido siguen adoleciendo de problemas semejantes a los de otras áreas que cuentan con su presencia. El lobo no es el causante del éxodo rural, de los movimientos migratorios del campo a la ciudad, de la paulatina desaparición de ese mundo rural, por otra parte, tan rico en matices y con un futuro que podría ser muy prometedor.

\section{Breve aproximación histórica}

Los orígenes de la estrecha interacción entre Canis lupus y Homo sapiens nos lleva a retroceder en el tiempo. Ambas especies han ocupado la mayoría de los biotopos del planeta, ambas han sido depredadoras y ambas, en ocasiones, pueden haber competido. Si retrocedemos unos 6 millones de años, encontramos una rama evolutiva de los primates que condujo al género Homo; y en los últimos 200000 años, la especie Homo sapiens ha llegado a dominar la vida en la Tierra ${ }^{6}$. Unos 8 millones de años atrás, los caninos, subgrupo moderno de los cánidos, se dividieron en canes (perros y lobos modernos) y vulpinos (zorros); el Xenocyon, hace un millón de años, representa la forma en la que perros y lobos modernos evolucionaron ${ }^{7}$.Pero en su evolución a lo largo del tiempo, a diferencia de sapiens, los lobos han ido desapareciendo de amplias zonas antes ocupadas $y$, desde esa época, han ido extinguiéndose subespecies, algunas en tiempos recientes, como por ejemplo, el lobo de las islas Malvinas (Dusicyon australis), cuyo último espécimen vivo se contabilizó en la segunda mitad del siglo XIX ${ }^{8}$.

Si comparásemos la evolución de la población de humanos y la de lobos, sin duda, llegaríamos a la conclusión del éxito evolutivo de los primeros frente a la regresión de los segundos: "La población, por tanto, puede ser una primera, aunque grosera, señal de bienestar. El millón de habitantes del Paleolítico, los 10 millones del Neolítico, los 100 de la Edad del Bronce, los 1.000 millones de la revolución industrial, o los

\footnotetext{
112.

${ }^{6}$ Parker, S., Evolución. Toda la historia, (Barcelona 2016), 14.

${ }^{7}$ Parker, op.cit., 489.

${ }^{8}$ Ibid., 489.
} 
10.000 millones que alcanzaremos, sin duda, en el siglo XXI señalan un crecimiento que, ciertamente, no es solo demográfico." Siguiendo este argumento, podríamos añadir que el lobo se halla en una fase de absoluta precariedad, dada su paulatina disminución poblacional, quizá, inversamente proporcional a la humana.

Siguiendo las palabras del profesor Livi Bacci, experto en demografía, puede afirmarse que la población humana no ha ido siempre en progresión, sino que ha habido períodos de crisis demográficas importantes: "... la evolución demográfica no ha sido uniforme en el tiempo: ésta se ha desarrollado mediante ciclos de expansión, estancamiento e incluso reducción, cuya interpretación no es fácil ni siquiera para aquellos períodos históricos no envueltos en las tinieblas". ${ }^{10} \mathrm{La}$ evolución de ambas especies, lobos y humanos, es divergente. Aún así, también es probable que haya habido períodos de mayor estabilidad, tal vez durante milenios, en cuanto a la población de lobos. Eso sí, la tendencia al alza, en relación con la población humana, es una constante; mientras que, para la población de lobos, aún a falta de estudios que analicen su evolución en largos períodos de tiempo, fácilmente podemos aceptar que ha debido ser a la baja, sobre todo si nos circunscribimos a las últimas centurias.

Estudiosos del perro (Canis lupus familiaris) desde el campo de la biología, los Coppinger señalan un problema añadido a la conservación del lobo, al igual que otros grandes carnívoros. Hace unos 12000 años, con el final de la última Era Glacial:

... los cánidos salvajes, como muchos otros mamíferos, se hicieron más pequeños. (...) Quizá sería más exacto decir que los miembros más grandes de la familia de los lobos, tales como el Canis dirus, se extinguieron mientras que los más pequeños florecieron. Es posible que el lobo gris sea otra reliquia de la Era Glacial que está en camino de extinguirse. La teoría sostiene que a medida que la tierra se va calentando, el nicho que ocupan las especies más grandes desaparece. Las especies pequeñas se adaptan mucho mejor ${ }^{11}$.

Así, puede admitirse que el calentamiento global del planeta, sin ser un agente social implicado en la conservación del lobo, también entra de lleno en la ecuación apuntada al principio del capítulo. El calentamiento del planeta viene provocado por la acción humana, y eso nos hace directamente responsables de la conservación de las especies silvestres.

La mayor paradoja de esta relación entre lobos y humanos es que, quizá, fue Canis lupus el animal silvestre que permitió a sapiens dar el primer paso hacia la domesticación animal. Este hecho sería fundamental en la evolución de sapiens hacia el estatus de especie dominante del planeta. Darwin cría que el perro procedía de varias especies de cánidos salvajes: “...respecto a los perros domésticos de todo el mundo, he llegado a la conclusión, después de una laboriosa recopilación de todos los datos conocidos, de que han sido amansadas varias especies salvajes de cánidos, y que su sangre, en algunos casos totalmente mezclada, corre por las venas de nuestras castas domésticas". ${ }^{12}$

Konrad Lorenz expone como pudo ser el origen del perro en una entrañable historia cuyo protagonista es el chacal dorado (Canis aureus). Lorenz, no obstante, admite que el cruce con otras especies, entre ellas el lobo, fue lo que condujo a la aparición del perro: “...hoy se sabe que muchísimos animales domésticos proceden de más de una especie salvaje primitiva." ${ }^{13}$ Posteriormente, admitió la procedencia única del lobo.

Tras largos debates a lo largo de los últimos cien años, existe un cierto consenso en que el único progenitor de todos los perros domésticos es el lobo gris (Canis lupus). Los restos arqueológicos sobre perros datan de unos 14.000 años, mientras que los estudios de biología molecular podrían indicar un origen mucho más antiguo ${ }^{14}$. La Dra. Clutton-Brock, señalaba que el problema actual para la comunidad científica está en cuándo, dónde y cómo se realizó la domesticación ${ }^{15}$.

En la actualidad, la arqueología cuenta con otra ciencia esencial para descubrir esos interrogantes, la genética. Así, se ha podido comprobar la gran similitud que existe entre ambos, ya que el ADN mitocondrial del perro es idéntico al del lobo en un $99,8 \%$ de su secuencia. ${ }^{16}$ La exploración de esta doble vía es la vigente para avanzar en el tema y, como ejemplo, cabe citar un artículo del Dr. Greger Larson, actualmente profesor en la Universidad de Oxford, con el que colabora un gran elenco de especialistas en la materia de la comunidad científica internacional, y en el que hacen un ejercicio colectivo de repensar la domesticación del perro a partir

\footnotetext{
${ }^{9}$ LiviBacci, M., Historia mínima de la población mundial, (Barcelona 2019), 10.

${ }^{10}$ LiviBacci, M., op. cit., 10.

${ }^{11}$ Coppinger, R., Coppinger, L., Perros. Una nueva interpretación sobre su origen, comportamiento y evolución, (Madrid, 2004$), 286$.

${ }^{12}$ Darwin, Ch., El origen de las especies, (Barcelona, 1979), tomo I, 27.

${ }^{13}$ Lorenz, K., Cuando el hombre encontró al perro, (Barcelona, 2010), 26.

${ }^{14}$ Manteca, X., Etología veterinaria, (Barcelona 2009), 10.

${ }^{15}$ Clutton-Brock, J, Origins of the dog: The archaeological evidence, The domestic dog. Its evolution, behavior and interactions with people, (New York 2016) 7ss

${ }^{16}$ Manteca, X., op. cit., 11.
}

150 Derecho Animal. Forum of Animal Law Studies, vol. 12/2 
de la integración de distintas disciplinas. ${ }^{17}$

El perro ha sido valorado por la inmensa mayoría de culturas del planeta y, por el contrario, pocas han respetado al lobo. Y, sin embargo, el origen del animal doméstico por excelencia es el lobo, motivo que debería ser suficiente para que tuviera nuestro respeto. Sin el perro, el desarrollo de la ganadería extensiva, tal como la conocemos, no habría sido posible.

Al menos en la prehistoria, el lobo no debió percibirse como una criatura dañina, si atendemos al carácter benefactor que presenta para algunas culturas ${ }^{18}$. En mi opinión, la idea extendida de que en el Neolítico, con la aparición de la agricultura y la ganadería, el lobo se convierte en enemigo irreconciliable del ser humano, no creo que sea del todo correcta. En la prehistoria, difícilmente hubo un serio problema entre las sociedades humanas y el lobo; no creo apropiado hablar de una difícil relación entre las dos especies, porque es presuponer que en todo momento ha sido la misma, extrapolando la situación de las últimas centurias a espacios temporales muy lejanos.

La densidad de población humana prehistórica no debió significar un grave problema para la coexistencia con el lobo. La principal fuente de comida de esos lobos no fue la cabaña de sapiens, sino la rica y aún no diezmada fauna silvestre sobre la que depredaba en ecosistemas sanos. No es muy creíble pensar que en los primeros tiempos de actividad ganadera surgieran graves conflictos con el lobo como los que se han originado en el último milenio.

Además, como apunta Grande del Brío, el lobo se caracteriza por la amplitud de su espectro alimentario. Es un animal carnívoro, y depreda sobre todas las especies de cérvidos (ciervo, corzo,...), bóvidos (cabra, muflón,...), jabalíes, lagomorfos (como la liebre), y en ocasiones sobre perros y zorros, y también llega a comer frutos; hasta salmones en los ríos de la Columbia Británica ${ }^{19}$. También actúa como carroñero. Así que no sería descabellado pensar que la cabaña ganadera debió entrar en su dieta más tarde de lo que se cree.

\subsection{La raíz del problema}

Los seres humanos se han alimentado exclusivamente mediante la caza de animales salvajes y la recolección de plantas silvestres hasta hace unos 11000 años. Luego, apareció la domesticación de ciertos animales y plantas: "...algunos pueblos se dedicaron a la "producción de alimentos": es decir, la domesticación de animales salvajes y el cultivo de plantas, y el consumo del ganado y las cosechas resultantes". ${ }^{20}$ Estamos ya en el período Neolítico, considerado como uno de los más trascendentales en la evolución de la Humanidad. Indaguemos un poco en el espacio geográfico que nos ocupa, la Península Ibérica, y en su devenir histórico.

Entre los pueblos de la Península Ibérica anterior a la ocupación romana no existía una homogeneidad en cuanto a sus actividades económicas: en unas áreas, la agricultura era limitada y seminómada; en otras, como en las vegas de los ríos Ebro, Segura y Guadalquivir, la agricultura se desarrolló en mayor medida; y también hubo otras, como en el norte, donde "el pastoreo y la agricultura de subsistencia presentan un carácter más duradero". ${ }^{21}$ Esta situación nos induce a pensar que con anterioridad a la ocupación romana la conflictividad entre las comunidades asentadas en la Península Ibérica y el lobo debía ser reducida.

En las sociedades humanas que cuentan con animales domésticos, el ganado puede alimentar a un volumen de población más elevado que el sistema de alimentación basado en la caza y recolección de plantas comestibles. La ganadería y la agricultura conducen al incremento de la densidad de población humana. Cuando está alcanza ciertos niveles de desarrollo es cuando, seguramente, el conflicto entre animales silvestres depredadores, como el lobo, y los humanos se hace visible. Pero ese crecimiento económico y poblacional de la comunidad humana no sigue siempre una evolución lineal; la historia está plagada de crisis que suponen retrocesos económicos y demográficos.

Avancemos hasta la Edad Media, período histórico en la que la economía agraria es ya un eje fundamental:

Una de las formas de convivencia más decisiva que se produjo a lo largo de la Edad Media fue la que unió a los hombres (y a las mujeres) con los animales. No se trata de una convivencia simple, ni tampoco trivial. El contacto con las bestias tenía sus reglas e incluso sus propios condicionantes sociales o ideológicos. Los primeros son claramente apreciables por ejemplo en la caza, que solía ser una actividad

\footnotetext{
${ }^{17}$ Greger Larson et al., Rethinking dog domestication by integrating genetics, archeology, and biogeography en Proceedings of the National Academ of Sciencies USA, vol, 109, n²3, junio de 2012.

${ }^{18}$ Grande del Brío, R., El lobo ibérico. Biología, ecología y comportamiento, (Salamanca 2015), 17.

${ }^{19}$ Nieto Maceín, D., Lo que el lobo sabe. Ecoetología y conservación del lobo, (Valencia 2016), 37.

${ }^{20}$ Diamond, J., "Armas, gérmenes y acero. Breve historia de la humanidad en los últimos trece mil años", (Barcelona 2018$), 98$.

${ }^{21}$ Plácido, D., Hispania Antigua, en Fontana, J. y Villares, R., Historia de España, vol. 1 (2017), 125.
} 
reservada a las clases dominantes, cuyos miembros podían contar con el equipamiento adecuado armas, caballos, lebreles y partidas- para emprenderla con suficientes garantías de éxito; ello explica que en las ordenanzas municipales bajomedievales, por ejemplo, sean comparativamente más escasas las menciones a caza mayor que las que se dedican a la menor, dado que la primera solía estar afectada por monopolios y cotos típicos de los territorios de señorío. ${ }^{22}$

En este período de la historia, la ganadería suponía un recurso fundamental. Algunas especies, como los caballos, eran considerados bienes al alcance de unos pocos; los rebaños de ovinos y caprinos también suponían un recurso básico, sobre todo porque con su producción a gran escala podían mantener una mayor población. Eso implicaba el uso de grandes áreas de pastos. Así, las condiciones climáticas y el incremento de la cabaña hacían necesario trasladar el ganado en verano desde las tierras bajas hasta los pastos de altura, y a la inversa en invierno:

Todo ello suponía largos y penosos movimientos de rebaños, desplazamientos muy peligrosos que requerían fuertes escoltas armadas, las esculcas, pagadas por los ganaderos y cuyo funcionamiento fue regulado en fueros como el de Cuenca de 1190. La necesidad de protección era obligada, no sólo por la posibilidad siempre presente de aceifas procedentes del sur, sino también por los crecientes conflictos que el ganado suscitaba allá por donde pasaba. Ciertamente, los reyes podían dar alegremente todo tipo de franquicias que garantizaban que las ovejas pudieran pastar por todos los rincones del reino, pero al llegar los rebaños a una determinada localidad los lugareños argumentaban que sus pastos estaban reservados para sus propios animales y que el súbito paso de unos rebaños que, posiblemente ya a mediados del siglo XIII contaban sus cabezas por miles, arrasaba sus bienes comunales. ${ }^{23}$

Los principales problemas de la ganadería, ya en el siglo XII, derivaban más del enfrentamiento entre intereses humanos, que de las pocas cabezas que los lobos pudieran abatir.

Cabe señalar una distinción entre territorios; en la Corona Aragonesa, donde el ganado estante era abundante, los practicantes de una ganadería trashumante acabaron por ceder a los intereses de aquellos. A diferencia, en Castilla, los ganaderos que practicaban la trashumancia se organizaron en asambleas (mestas) para actuar de forma comunitaria en defensa de sus intereses. Y la monarquía castellano-leonesa optó por concederles privilegios: “...Alfonso X decidió en 1273 conceder privilegios al "consejo de los pastores de la Mesta", mediante los cuales les otorgaba a los trashumantes la protección regia, así como permiso para poder cortar madera allá donde se encontraran con sus rebaños, exención de impuestos de peaje (portazgos) y dispensa de las multas por la intrusión de los rebaños en los montes comunales (montazgos) excepto en aquellos en que existieran concesiones regias para la imposición de tales derechos." 24

Grande del Brío, historiador y naturalista estudioso de esta especie, señala que:

... el protagonismo del lobo como especie depredadora -mítica- por antonomasia, se mantuvo a lo largo de los siglos. La Edad Media verá renacer una serie de primitivas formas de superstición, que a pesar de la influencia del cristianismo, se hallaban informadas por el elemento pagano. Pero, al margen de leyendas y supersticiones, lo cierto es que, en el plano de la producción ganadera, el hombre ha asistido, ante la más cruda impotencia, al cruento espectáculo de los ganados domésticos muertos bajo los ataques de los lobos. ${ }^{25}$

Podemos estar de acuerdo con esta última afirmación, pero no creo que podamos comparar esas pérdidas con las que pudieran derivarse de las aceifas, expediciones militares sarracenas que se hacían en verano, o los conflictos entre los ganaderos trashumantes y los ganaderos estantes o agricultores.

En la Baja Edad Media se produjo una profunda crisis, con un declive de la población y una disminución de la demanda de productos agrícolas, agravada con la peste negra (1348), y que sí influyó en la situación del mundo rural ${ }^{26}$. La densidad de población humana no era elevada, como tampoco la actividad cinegética sobre la caza mayor. El lobo debía ocupar su nicho ecológico y, a buen seguro, contaba con alimento suficiente dentro de su hábitat, aunque en ocasiones depredara sobre la cabaña.

A finales del siglo XIV, la Mesta, una agrupación corporativa de ganaderos, había alcanzado una gran expansión, y el número de cabezas ovinas que representaba alcanzaba el millón y medio. Un siglo más tarde

\footnotetext{
${ }^{22}$ Manzano Moreno, E., Épocas Medievales, en Fontana, J. y Villares, R., Historia de España, vol. 2 (2017), 494.

${ }^{23}$ Manzano Moreno, E., op. cit., 497.

${ }^{24}$ Ibid., 498-499.

${ }^{25}$ Grande del Brío, R., op. cit., 222.

${ }^{26}$ Wallerstein, I., El moderno sistema mundial I, (Madrid 2016), 188.

152 Derecho Animal. Forum of Animal Law Studies, vol. 12/2
} 
doblaría su número; y en este cómputo no se incluiría el número de cabezas de los rebaños no trashumantes, que ascenderían a un millón y medio más. ${ }^{27} \mathrm{La}$ trashumancia creó diversas rutas (cañadas), una de ellas, la cañada leonesa, que iba desde León hasta el territorio de la Extremadura actual. La expansión de la ganadería trashumante en la mayoría de los reinos peninsulares del siglo XIII no supuso la desaparición del lobo en suelo peninsular. Los mayores problemas de la ganadería provenían de otros ámbitos distintos a la depredación de la fauna silvestre sobre la misma.

Avancemos en el tiempo. Los conflictos en el ámbito de la ganadería y las consecuencias negativas para el sector, sin relación con el lobo, continuaron:

El planteamiento extensivo con el que se había producido el crecimiento agrario del siglo XVI, con las inevitables disputas planteadas sobre los usos alternativos -y concurrentes- del espacio rural, constituía a su vez otra importante amenaza para los ganados mesteños, que veían peligrar la continuidad de los numerosos derechos de pasto que disfrutaba la Institución (la Mesta). ${ }^{28}$

En el siglo XV se incrementó la ganadería, tal vez por los precios de la lana como por los de la carne, que "parecían haber resistido en mayor grado los efectos de la depresión, y, además, los costos de la mano de obra, entonces escasa, eran aquí menores." 29

La documentación histórica parece indicar que en la ganadería ovina se produjo un cambio de tendencia:

“...la pérdida de la hegemonía que hasta entonces había venido manteniendo el ganado trashumante en relación con los estantes y riberiegos, cuyos desplazamientos eran de radio más limitado. Mientras los primeros acusan un claro descenso, los segundos conocerán un período de estabilización cuando no de aumento." ${ }^{30}$ En ese cambio no tuvo nada que ver el lobo, sino "...el hundimiento de las exportaciones laneras -iniciado poco antes de la crisis comercial del último tercio del siglo XVI- tuvo un papel crucial." ${ }^{31}$ En el siglo XVI, en una economía en expansión, la rentabilidad del trigo sacó ventaja a la lana $^{32}$.

En estos tiempos, y refiriéndonos directamente al lobo, “... en pleno siglo XVI, dichos depredadores colonizaban la práctica totalidad de los diferentes biotopos, alcanzando la costa. En el siglo XVII, la caza del lobo se practicaba en los alrededores de Madrid" ${ }^{33}$. Grande del Brío señala que "la población de lobos debió de remitir ligeramente en los primeros siglos de la Edad Moderna, coincidiendo con la humanización del paisaje en ciertas áreas"; pero esas áreas peninsulares no creemos que coincidan en nada con las que en la actualidad cuentan con una cierta población de lobos. Esa reducción puede que se diera más en el levante peninsular, con menos ganadería extensiva; así que no se puede relacionar directamente la ganadería extensiva con el retroceso del lobo, sino con una mayor influencia de la actividad humana en áreas naturales.

La ganadería trashumante no desaparece; así, a finales del siglo XVII y durante el siglo XVIII se recupera, aunque pierden el control que habían venido ejerciendo sobre la institución de la Mesta. El historiador Fernández Albaladejo apunta, en relación con dicha institución, que “... se difuminaba en cualquier caso la connotación democrática que constitutivamente había venido caracterizando a la Mesta desde sus orígenes, emergiendo alternativamente la figura del señor de ganados" como encarnación del nuevo ideal social que pasaba a imponerse." 34

Lo cierto es que la caza del lobo ha sido una constante histórica, muchas veces ligada al presunto "gran daño" que ocasionaba al ganado doméstico: trampas loberas se distribuyen a lo largo de la geografía peninsular; batidas "obligadas" por ordenanzas, monterías, cacerías multitudinarias,..., pueden documentarse en múltiples documentos históricos ${ }^{35}$.

El siglo XVIII muestra una destrucción más generalizada de biotopos y, según Grande del Brío, el lobo continúa “... su "dramática" carrera como depredador, pero cada vez más dependiente, en ciertas zonas, de los rebaños domésticos y, por ello mismo, también más adscrito al entorno humano."36

Desde la segunda mitad del siglo XIX, la acción de los alimañeros, la destrucción de hábitats, las batidas

\footnotetext{
${ }^{27}$ Manzano Moreno, E., op. cit., 499.

${ }^{28}$ Fernández Albaladejo, P., La crisis de la monarquía, en Fontana, J. y Villares, R., Historia de España, vol. 4 (2017), 289.

${ }^{29}$ Wallertsein, I., op. cit., 188.

${ }^{30}$ Fernández Albaladejo, P., op. cit., 288.

${ }^{31}$ Ibid., 288.

${ }^{32}$ Wallerstein, I., op. cit., 189.

${ }^{33}$ Grande del Brío, R., op. cit., 223.

${ }^{34}$ Fernández Albaladejo, P., op. cit., 289.

${ }^{35}$ Grande del Brío, R., op. cit., 283-301.

${ }^{36}$ Ibid., 223.
} 
y el uso de estricnina, fueron motivo de la reducción de la población de lobos. Así, a finales del siglo XIX habían desaparecido de la costa mediterránea. En cambio, subsistió“....principalmente, en aquellas áreas donde las condiciones de vida en que el hombre se desenvuelve, no han implicado grandes alteraciones ecológicas. En otras zonas más humanizadas, el lobo ha perdido significación como animal eminentemente depredador" ${ }^{37}$.

Paralelamente, la ganadería en el siglo XIX sufrió las depredaciones de la guerra de la Independencia y los conflictos carlistas. Estos hechos provocaron un notable quebranto en la actividad. Josep Fontana, historiador, refiriéndose al ganado vacuno, el lanar y el cabrío, señala que los rebaños trashumantes se contrajeron por la quiebra de las exportaciones de lana española, ante la competencia que sufrieron en los mercados internacionales por las lanas sajonas: “...de modo que al abolirse los privilegios de la Mesta, en 1836 , los grandes rebaños trashumantes estaban ya en franca decadencia. A lo que hay que añadir que las roturaciones redujeron las superficies destinadas a pastos." 38

Aún así, Ramón Tamames apunta que "el régimen de trashumancia se mantuvo durante todo el siglo XIX y aún quedan vestigios en nuestros días; pero la roturación de pastizales para dedicar las tierras a los cultivos agrícolas, su reducción en las áreas que se acotaron para la repoblación forestal, la elevación de los precios de arrendamiento, la escasez de pastores $y$, en general, todo el anacronismo del sistema fueron acabando con la trashumancia, que en general se convirtió en un mal negocio." 39

Como se ha visto en esta breve incursión en el devenir de la historia, en la Península Ibérica el sector ovino trashumante ha tenido una especial relevancia en el mundo rural y en su sector ganadero. $\mathrm{Y}$ en su evolución han pesado siempre más las consecuencias derivadas de las propias relaciones humanas, del entorno económico, social y político, que las interacciones con la naturaleza y los animales silvestres.

El problema de la ganadería extensiva, de sus productos comercializados, como la lana, es complejo, por las características que presenta tanto del lado de la oferta (ganaderos), como del de la demanda (comerciantes e industriales). Este fenómeno, de absoluta actualidad, no es solo contemporáneo, sino que, como hemos ido esbozando en estas páginas, se ha producido a lo largo de toda la historia.

Ya en el siglo XX, la cabaña se redujo entre los censos de 1933 y 1955, provocando problemas de abastecimiento de alimentos, lana y cueros, que presionaron fuertemente sobre el comercio exterior. Esta reducción tuvo como consecuencia una separación entre agricultura y ganadería aún mayor que la ya tradicional en nuestro campo, que se caracteriza por un subsector pecuario con un peso relativo bajo dentro de la producción final agraria (del tipo del $40 \%$ frente a niveles del $60 \%$ al $80 \%$ en otros países europeos)." 40 Tamanes remarca la idea de que en España no existe una sola agricultura o ganadería:

La región gallega, asturiana, cántabra, vasca y leonesa, son las que muestran un mayor desarrollo ganadero, especialmente ganado vacuno. En las dos Castillas tiene mayor peso el ganado ovino, y en Cataluña y Levante, destaca el porcino y la avicultura, mientras que en Andalucía y Extremadura se da un cierto equilibrio entre la ganadería porcina, vacuna y ovina; pero en todas ellas, la intensidad ganadera es inferior al área norte peninsular. En el norte, la alimentación del ganado sigue siendo básicamente de pastos naturales o mejorados. ${ }^{41}$

Por el contrario, el desarrollo de la ganadería estante no ha sido tan trascendental: "el desarrollo de la ganadería estante sólo se aceleró a partir de la segunda mitad del siglo XIX y, de modo especial, en los primeros treinta años del presente siglo (s. XX)."42 La explotación del ganado ovino en el régimen estante tradicional, "...es un rudimentario modo de casar las conveniencias agrícolas con las ganaderas, pero no constituye una explotación pecuaria propiamente dirigida." 43 Distinto es el régimen de ganadería con rebaños grandes en áreas organizadas, donde un pastor puede manejar de 200 a 400 ovejas, y hasta multiplicar por dos, tres o cuatro estos números en pastos cerrados; aquí los costes se reducen considerablemente y la competitividad aumenta. La ganadería estabulada, de ceba de corderos, se generaliza a lo largo del siglo XX, con unos mejores rendimientos, mientras que el censo de ganado lanar decrece hasta 1981.44Tamames señala que a partir de ese año se recuperó el censo de ganado lanar por los altos precios que se pagaban por la carne de ovino y por su leche, pero, también, por la política de apoyo a la creación de cebaderos registrados y ayudas comunitarias.

Está claro que es en el noroeste peninsular donde ha sobrevivido la escasa población del lobo ibérico.

\footnotetext{
${ }^{37}$ Grande del Brío, R., op. cit., 225.

${ }^{38}$ Fontana, J., La época del liberalismo, en Fontana, J. y Villares, R., Historia de España, vol. 6 (2017), 416.

${ }^{39}$ Tamames, R., Estructura económica de España (Madrid 1990), 175.

40 Tamames, R., op. cit., 163-164.

${ }^{41}$ Ibid., 165.

42 Tamames, R., op. cit., 162.

${ }^{43}$ Ibid., 175.

${ }^{44}$ Ibid., 175.

154 Derecho Animal. Forum of Animal Law Studies, vol. 12/2
} 
En otros territorios con mucha menor repercusión histórica de la ganadería extensiva es donde el lobo se ha extinguido o pervive con escasas probabilidades de supervivencia. Las nuevas técnicas de producción ganadera, el desarrollo de sectores productivos distintos al ganadero, el crecimiento demográfico y, por ende, urbano, han sido mucho más letales para el lobo que la actividad ganadera extensiva. Sorprende que en los territorios donde ésta aún persiste, se culpe al lobo de muchas de sus desgracias, analizando lo que ha sucedido en todo el territorio peninsular. Grande del Brío se lamenta de la desaparición del lobo de amplias zonas de la Península Ibérica, “...porque ha privado a los investigadores, de la oportunidad de ofrecer una visión comparativa sobre las diferentes poblaciones del este y del oeste". ${ }^{45}$

Analizar con cierta profundidad la política agraria del Estado español en el siglo pasado es un tema que excede el ámbito de este trabajo, pero que sería de gran interés para interpretar correctamente la situación del mundo rural en la actualidad. Los problemas básicos de la ganadería son variopintos, como la dimensión de las explotaciones ganaderas, la selección de razas, la alimentación o la sanidad animal. Sintetizando, y dentro del marco económico general, “...hasta bien entrados los años 50 se protegió denodadamente la industria, se fomentaron ciertos tipos de cultivo (trigo, plantas industriales, etc.), hubo una labor de importancia en la repoblación forestal; pero nada o casi nada se hacía por la ganadería. Casi toda la política ganadera hasta 1964 cabe resumirla en dos decretos de 28 de octubre de $1955^{\prime \prime 46}$, que no se llevaron a la práctica y que fueron derogados en 1963. No obstante, un factor sí fue decisivo en el desarrollo de un crecimiento ganadero a partir de la década de los 60 , y fue el consumo, que creció junto con el nivel de renta de la población y la creciente demanda de la producción ganadera, todo ello dentro de un mercado protegido del exterior ${ }^{47}$.

Tal vez, en el tema de la lana, si puede decirse que:

...estuvo durante largos años dentro del régimen de comercio de Estado, lo que representaba para la lana nacional el máximo de protección de la competencia extranjera. En enero de 1962, en razón a los compromisos adquiridos por España en la OCDE, y como consecuencia de la presión de la industria textil, se liberó la importación de lana... El resultado fue una difícil realización de las ventas, ante la preferencia de los industriales nacionales por las lanas australianas; situación que aún se hizo más evidente con la incorporación de España a la CEE... ${ }^{48}$.

Tamames señala el hecho de que el ingreso en la CEE, que parecía un gran paso para el futuro del ganado ovino, no lo fue en la medida esperada, debido a los compromisos adquiridos respecto a terceros países, compensada sólo por los subsidios directos por oveja. ${ }^{49}$

Con la entrada en la CEE, en 1986, las tendencias siguen siendo parecidas, si bien en un contexto de cierta complejidad ${ }^{50}$. Si nos fijamos en el sector del ovino y caprino, la regulación comunitaria abarca un triple frente: régimen de precios e intervenciones, sistema de ayudas, y regulación de los intercambios con terceros países. Resumiendo, sin acciones directas en este sector por parte de los poderes públicos, sean comunitarios o estatales, sin una política agraria comunitaria que defienda el mantenimiento del sector y una implicación estatal en la misma línea, el comercio mundial, la economía global, posiblemente habría reducido la ganadería española a su mínima expresión.

Si visualizamos, someramente, la evolución del sector ganadero peninsular a lo largo de la historia, puede afirmarse que ha discurrido entre unas épocas de gran relevancia económica, y otras en las que solo ha supuesto un añadido más al sector agrario. Todos estos procesos, con sus alzas y bajas, se han producido independientemente de la acción del lobo sobre la cabaña. Presumiblemente, el peor período histórico que le ha tocado vivir al lobo no está en el de la competencia con Homo sapiens en épocas prehistóricas, ni en la Antigüedad, ni tampoco en los "años oscuros" que para algunos supone la Edad Media. Tal vez el punto de inflexión se dio cuando los europeos iniciaron la expansión hacia nuevos continentes, o cuando eclosionó la revolución industrial. Y seguro, sin ningún género de dudas, en el siglo XX.

El siglo pasado, conocido como el de la revolución científica, ha traído cambios trascendentales para el devenir de la Humanidad, en multitud de campos (tecnológico, comunicaciones, derechos humanos y sociales,...). Junto a todo ello, también ha traído la mayor aceleración en la destrucción de la biodiversidad y de los hábitats naturales; y con un principal causante: la especie humana. El lobo, como otras muchas especies silvestres, es solo una más de las que sufren la progresiva desaparición de la mayoría de los hábitats que ocupaban no hace más de un par de centurias.

\footnotetext{
${ }^{45}$ Grande del Brío, R., op. cit., 15.

${ }^{46}$ Tamames, R., op. cit., 168.

${ }^{47}$ Ibid., 169.

${ }^{48}$ Tamames, R., op. cit., 175.

${ }^{49}$ Ibid., 176.

${ }^{50}$ Ibid., 171.
} 
La movilización para la defensa de esos hábitats es, en términos históricos, muy reciente, y se gesta en el seno de la ciudadanía. Áreas forestales entendidas como espacios naturales para la preservación de especies de flora y fauna, son un hecho apreciable en esta dirección: "La política conducente a este fin se acometió primeramente en Estados Unidos por una Ley de 1872, promovida por un grupo de ciudadanos del Estado de Montana, que pidieron la creación del primer parque nacional, el hoy mundialmente célebre "Yellowstone National Park". ${ }^{51}$ Tamames señala que en España la preocupación por preservar ciertas áreas naturales se produce en 1916, con la aprobación de una normativa concreta. En 1918 se crearon los dos primeros parques nacionales, Covadonga y Ordesa. No obstante, hasta 1954 no se creó ningún otro parque nacional. Ya en el período democrático, de 1977-1981, “... tomando como base la ley de 1974 de espacios naturales, reclasificaron y ampliaron los nueve parques nacionales. Lo cual no significa que con ello, y con toda una serie de medidas ulteriores, quedaran a resguardo de numerosas y graves agresiones; ..." ${ }^{\prime 5}$.

La ley 4/1989, de 27 de marzo, sobre fauna y flora silvestre y espacios naturales, supone una revisión de la gestión en la materia, ampliando las áreas protegidas. Pero no supone que todo el tema se recondujera hacia "...el mejor orden". 53

Tradicionalmente, es un hecho sabido que el lobo no ha tenido buena prensa. Con esta breve incursión a lo largo de la historia, no obstante, comprobamos que esta especie silvestre no ha sido un factor de peso en los balances económicos de la actividad ganadera. El lobo se ha abastecido sin grandes problemas en el seno de los ecosistemas de los que formaba parte; su rapiña sobre la cabaña ganadera, aunque real, no debía ser tan abundante como la tradición popular puede dar a entender.

Aferrarse a planteamientos esgrimidos desde hace tiempo, dar por hecho afirmaciones sin un análisis crítico sobre las mismas, en muchas ocasiones, no ayuda a visibilizar correctamente el problema y actuar con objetividad; en consecuencia, no facilita la búsqueda de vías adecuadas para su solución. Como ya hemos señalado, el lobo no es el culpable del éxodo rural acaecido en toda Europa, especialmente en los siglos XIX y XX. Tampoco lo es de la evolución económica que ha llevado al sector ganadero del Estado español a una situación precaria. Ni es el culpable de la despoblación actual del mundo rural, ni de las políticas agrarias establecidas por los poderes públicos o de las PAC. Creemos que todos los agentes implicados en la gestión y protección del lobo pueden estar de acuerdo con estas afirmaciones.

\subsection{Evolución de la población y distribución del lobo}

Los zoólogos hablan de más de 30 razas de lobos 54 ; "la mayor parte de las razas de lobos, habita la amplia franja biogeográfica comprendida al norte de América Central hasta el Ártico y que se extiende por el norte de África, todo el continente europeo, norte de la Península Arábiga y norte del Himalaya hasta el Océano Pacífico. Dicha franja recibe el nombre de región holártica." ${ }^{55}$ Nuestro lobo ibérico (Canis lupus signatus) pertenece a las razas de lobos pardos, con pelaje de coloración grisácea más o menos oscura, y de latitudes más meridionales. Es una subespecie del lobo común europeo (Canis lupus lupus), autóctona de la Península Ibérica.

Las actuales poblaciones de lobos europeos cuentan con muy pocas poblaciones con núcleos de cierta importancia; eso quiere decir que predomina la dispersión y el aislamiento, lo que contribuye a una diminución de la salud genética de la especie ${ }^{56}$. La población de lobos de la Península Ibérica sufre ese aislamiento respecto a las poblaciones de lobos de Centroeuropa e Italia; y también esa dispersión y aislamiento en relación con la propia población lobera peninsular. Es decir, que la especie cuenta con una muy frágil salud genética:

“... los lobos de la Península Ibérica que ocupan enclaves en Sierra Morena, la sierra de San Pedro y el Sistema central, pueden, hoy, considerarse, a todos los efectos, como grupos aislados del resto de las poblaciones del noroeste,...". ${ }^{57}$

La extinción del lobo en amplios territorios de Europa viene de tiempo atrás. En Inglaterra, el lobo fue exterminado sobre el 1500; en Escocia, sobrevivió hasta su extinción en 1680; Irlanda, en 1770; en el territorio de la Alemania Occidental -anterior a la unificación alemana-, se extinguió en 1890; Suiza, en 1947; en Francia, a mediados del siglo XIX ${ }^{58}$.

\footnotetext{
${ }^{51}$ Ibid., 185-186.

52 Tamames, R., op. cit., 186

${ }^{53}$ Ibid., 186.

${ }^{54}$ Rodríguez de la Fuente, F., Cuadernos de campo. El lobo, (Barcelona 1978), 12.

${ }^{55}$ Grande del Brío, R., op. cit., 29.

${ }^{56}$ Ibid., 35.

${ }^{57}$ Grande del Brío, R., op. cit., 35.

${ }^{58}$ Rodríguez de la Fuente, F., op. cit., 15.

156 Derecho Animal. Forum of Animal Law Studies, vol. 12/2
} 
En la década de los 70, la mayor concentración de la población de lobos europea se centraba en tres países: Polonia, la antigua Yugoeslavia y Finlandia. A continuación, se encontraba España, con una población aproximada de 700 ejemplares, en su valor máximo estimado; Grecia e Italia le seguían en volumen poblacional, con un cálculo de unos 300 ejemplares ${ }^{59}$. Félix Rodríguez de la Fuente ya apuntaba como principal peligro de estas poblaciones su aislamiento, como era el caso de los lobos de la Península Itálica y la Península Ibérica.

Si nos fijamos, en las islas británicas, donde el lobo se encontraba aislado y no tenía ninguna vía de escape, fue cazado y aniquilado mucho antes que en el territorio europeo continental. En el centro europeo más occidental tampoco tuvo mucha suerte, y acabó extinguido en países como Alemania, Suiza o Francia, aunque mucho más tarde que en las islas británicas; con toda seguridad, por tener mayores oportunidades de desplazamiento cuando era perseguido de manera sistemática. Los países mediterráneos mantenían en la década de los 70 del siglo pasado una cierta población lobera, aunque fuera muy exigua.

La distribución geográfica del lobo en la Península Ibérica, en la década de los 70, era muy restringida y variaba cada año como consecuencia de la persecución constante. Félix Rodríguez de la Fuente apuntaba: "La situación resulta ya dramática, teniendo en cuenta que hace solo 50 años, el lobo ibérico se distribuía por la casi totalidad de la península" ${ }^{60}$. También comentaba que encontrar un lobo en la naturaleza resultaba muy difícil. Acantonado en las montañas del cuadrante noroccidental de la península, no era este su biotopo original, ya que décadas atrás ocupaba marismas, bosques de encinas y alcornoques, bosque mediterráneo, estepas cerealistas, bosques caducifolios, bosques de coníferas, y alta montaña ${ }^{61}$.

Rodríguez de la Fuente señalaba la facilidad de desplazamiento del lobo y su relativo nomadismo, lo que conducía a la sensación engañosa, para algunos, que el número de lobos era mayor del real ${ }^{62}$.

En la Península Ibérica, el papel ecológico del lobo es el de superpredador:

... en los ecosistemas con escasa intervención del hombre..., ejerce un claro papel de limitador y controlador de las poblaciones de herbívoros que, sin su concurso, llegarían a ser numerosas y pondría en peligro los recursos vegetales del entorno. Pero las modificaciones introducidas por el hombre en la mayoría de los hábitats terrestres, han producido un cambio en el papel del lobo. La desaparición de la mayor parte de las poblaciones de animales ungulados silvestres y su sustitución por los domésticos, han provocado -en aquellos lugares donde todavía sobrevive-, su desafortunada necesidad de atacar a la cabaña ganadera que, en el fondo, solo representa para el lobo, lo que ha conocido desde tiempos inmemoriales, es decir, presas para su alimento. ${ }^{63}$

El lobo, como señala Grande del Brío, suele aprovechar la carroña como complemento de su dieta. Y esta faceta carroñera, sin ser nueva, va creciendo en ciertos lugares del noroeste de la Península Ibérica y del centro de Italia. Esta nueva situación se debe a la destrucción de los biotopos y la humanización del paisaje. $\mathrm{Y}$ es esencial que esta tendencia se controle y no se incremente, ya que el lobo puede perder parte de su función depredatoria sobre poblaciones de herbívoros salvajes, tan necesaria para el equilibrio de los ecosistemas. Grande del Brío apunta que esta alteración puede verse en parte de la población de lobos galaica.

Donde existe equilibrio ecológico, el lobo prefiere presas de gran talla; así, en el caso de la Península Ibérica, el corzo entra a formar parte de la alimentación del lobo en altos porcentajes, en ciertas áreas del noroeste. El ciervo aparece también con alguna frecuencia. En su dieta: "Los mamíferos domésticos representan un porcentaje muy variable en el espectro alimentario del lobo, en función del tipo de hábitat, la disponibilidad de presas salvajes y otros factores. A través de los estudios realizados por diversos autores, se desprende que la incidencia del lobo, sobre la cabaña ganadera, viene determinada, en buena medida, por la mayor o menor abundancia de presas salvajes de gran porte." 64

Resulta que donde escasean los grandes herbívoros, el lobo tiende al consumo de ganado doméstico: "Ello resulta particularmente notorio en Portugal y en sudoeste de la provincia de Salamanca (España), donde un $77,2 \%$ y alrededor de un $60 \%$, respectivamente, son los valores que habitualmente alcanza el ganado doméstico en la dieta del lobo." ${ }^{65}$ Aunque una gran parte de ese alto porcentaje es por consumo de carroña. Resulta paradójico que en Portugal se proteja al lobo, produciendo éste un mayor daño al ganado doméstico, y que en España el lobo no pueda tener esa protección.

\footnotetext{
${ }^{59}$ Ibid., 14.

${ }^{60}$ Ibid., 16.

${ }^{61}$ Ibid., 19.

62 Ibid., 19.

${ }^{63}$ Rodríguez, F., op. cit., 22-23.

${ }^{64}$ Grande del Brío, R., op. cit., 49-50.

${ }^{65}$ Ibid., 51.
} 
El consumo de presas domésticas disminuye en aquellos lugares en los que existen cérvidos y otro tipo de caza mayor. Si la actividad cinegética es alta, ésta incrementa la depredación del lobo sobre de la cabaña ganadera. Por tanto, el sector ganadero debería estar en desacuerdo con el desarrollo de una actividad cinegética desmesurada sobre las potenciales presas del lobo.

Investigadores del lobo, como Urios, Vilà y Castroviejo, señalan que para la conservación del lobo se hace necesaria su presencia en áreas extensas, y que los conflictos con la ganadería surgen cuando estas áreas “... cuentan con fuerte presencia humana como es en la Península Ibérica. (...) Evidentemente la proporción entre daños y número de lobos varía según la disponibilidad de presas salvajes y la cantidad de ganado que

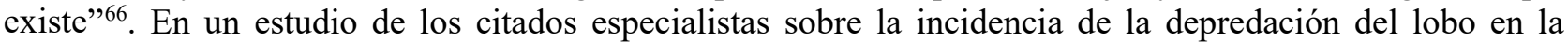
ganadería -realizado durante varios años (1987-1990) en un área entre las poblaciones de León y Zamora-, los datos obtenidos demuestran que el número de ataques registrados es bajo: $22,8 \%$ del total en excrementos, la mayoría debido al consumo de ganado como carroña (mortalidad natural) ${ }^{67}$. La principal conclusión del estudio es que cuando en los territorios existen presas salvajes suficientes y cuando el manejo de la ganadería es adecuado, los ataques del lobo al ganado son despreciables, aunque éste sí forma parte importante de la dieta como carroña.

Como superpredador, el lobo se convierte en una pieza esencial para el mantenimiento del equilibrio ecológico, ya que limita las poblaciones de otros carnívoros y controla la de los herbívoros ${ }^{68}$. Por tanto, su desaparición provoca graves problemas, como son el incremento no deseado de la población de zorros o la proliferación de perros asilvestrados, que ocasionan cuantiosos daños en la ganadería y en la caza. La eliminación de perros se produce, por lo general, en las zonas rurales donde abundan perros descontrolados que se adentran en territorio de los cánidos salvajes. ${ }^{69}$

En cuanto a la relación entre lobos y perros asilvestrados u otros, comúnmente nuestra actitud hacia esos perros es mucho más amistosa, desatendiendo el impacto negativo de los perros como depredadores. El Dr. Luigi Boitani, junto con otros biólogos, en un estudio sobre ecología y comportamiento de los perros asilvestrados del centro de Italia, exponen la actitud de pastores y agricultores, que culpan sistemáticamente a los lobos por la depredación del ganado, para obtener una compensación financiera. El resultado de este conflicto es una condena mucho mayor a la merecida para los lobos y la libre circulación de perros asilvestrados, que se convierten así en una de las principales amenazas para la conservación del lobo en Italia $^{70}$.

Mención especial merece el territorio del lobo, que constituye uno de los elementos integrantes de su espacio vital:

...no se trata de un área con límites rígidos, sino fijados en razón de la bondad del biotopo -amplitud de espacio, abundancia de alimento, etc.-. En la actualidad, debido a la intervención humana, el lobo se halla sometido a una serie de condicionantes que, en unos casos, restringen su movilidad, y en otros, la acrecientan. Indirectamente, la destrucción de la cubierta vegetal y la antropogenización del paisaje, son factores que inciden sobre la estabilidad de las diferentes poblaciones lobunas, provocando graves alteraciones. $^{71}$

El aumento del efecto antropogénico en el medio físico de la fachada costera y áreas cercanas ha sido básico para la desaparición del lobo; este hecho se ha producido en la fachada atlántica y en la mediterránea ${ }^{72}$. La persecución sistemática a la que fue sometido y la generalización del uso de venenos, como la estricnina, desde finales del siglo XIX, fueron elementos fundamentales en la mayoría de las extinciones en diversos territorios. En el Sistema Ibérico, en los Pirineos, en el País Vaso o en el Sistema Central, se extinguió, y si se localiza alguna población, es muy reducida y fluctuante. En cambio, las poblaciones más numerosas se ubican en el cuadrante noroccidental de la Península Ibérica, especialmente en Galicia, Asturias y CastillaLeón. Algunas, como las del norte y occidente de la provincia de Zamora, son relativamente estables o poco fluctuantes. ${ }^{73}$ Actualmente, existen datos sobre la presencia del lobo en CCAA como Madrid o Castilla-La

\footnotetext{
${ }^{66}$ Urios, V., Vilà, C., Castroviejo, J., Estudio de la incidencia real de la depredación del lobo en la ganadería comparando dos métodos distintos, en Revista Galemys 12 ( $\mathrm{n}^{\mathrm{o}}$ especial), (Málaga 2000), publicación de SECEM (Sociedad Española para la Conservación y Estudio de los Mamíferos), 241.

${ }^{67}$ Urios, V., Vilà, C., Castroviejo, J., op. cit., 243.

${ }^{68}$ Rodríguez, F., op. cit., 19.

${ }^{69}$ Nieto Maceín, D., op. cit., 185.

${ }^{70}$ Boitani, L., et al., The ecology and behavioral of feral dogs: A case study from central Italy, en The domestic dog. Its evolution, behavior and interactions with people, (New York 2016), 364.

${ }^{71}$ Grande, op. cit., 99

72 Ibid., 228.

${ }^{73}$ Grande, op. cit., 208.

158 Derecho Animal. Forum of Animal Law Studies, vol. 12/2
} 
Mancha, pero sería población fluctuante no consolidada. Y es en la comunidad autónoma de Castilla-León donde la población de lobos se halla en una situación más favorable.

Un documento del Ministerio de Medio Ambiente señala que en España pueden diferenciarse tres núcleos: la población noroccidental, en ambas vertientes del Duero, la más estable, numerosa y en cierta expansión; una población relicta en Sierra Morena, en peligro crítico de extinción; y un reducido número de lobos en los Pirineos, en proceso de recolonización y no estable, procedentes de Francia e Italia ${ }^{74}$.

A nivel de todo el Estado español, los censos oficiales calculan una población de lobos que podría rondar los 2.000 ejemplares $^{75}$. Estudios realizados desde el ámbito de las AAPP, y promovidos por el ministerio con competencias en medio ambiente, recomiendan actualizar, al menos cada 10 años, la información sobre la distribución y el tamaño de la población de lobos. El último censo nacional de la especie, cuyos trabajos de campo han sido realizados por las comunidades autónomas, se realizó entre 2012 y 2014.

No obstante, un estudio basado en el análisis de marcadores genéticos de ejemplares de lobo ibérico de la Península Ibérica rebaja esa cantidad a una cuarta parte. ${ }^{76}$ En este estudio, llevado a cabo por investigadores de la UAB y de la UPF-CSIC, se llega a la conclusión que el lobo ibérico ha estado en el umbral de la extinción durante el siglo pasado, y que, o bien se subestimaron los efectos genéticos de las reducciones de la población del lobo ibérico ("cuellos de botella"77), o bien hay una sobreestimación del número actual de lobos en la Península Ibérica. Por ello, es absolutamente necesario asegurar la conservación del lobo mediante un crecimiento constante de las poblaciones, evitando la fragmentación de la población y posibilitando la comunicación entre territorios. Los investigadores del estudio en cuestión creen que para la población del lobo ibérico sería deseable evitar la fragmentación de las poblaciones y los territorios, facilitando así el flujo genético entre la población del noroeste, más numerosa, con los núcleos aislados del sur (Sierra Morena) y noreste (Cataluña) de la Península Ibérica.

Como señalábamos, existe una posibilidad de que en los Pirineos puedan establecerse lobos de manera estable, aunque en la actualidad son poblaciones fluctuantes no consolidadas. Estos ejemplares son el lobo común europeo (Canis lupus lupus) y la subespecie autóctona de la Península Itálica (Canis lupus italicus); podrían acceder a la Península Ibérica a través de la cordillera pirenaica, en especial la subespecie procedente de Italia, en cierta expansión.

Los lobos, como otros mamíferos, efectúan desplazamientos migratorios, abandonando temporalmente sus territorios habituales para instalarse en otros. Este fenómeno puede producir errores en la contabilización de la población de lobos, así como problemas a nivel de protección de los lobos, ya que según su ubicación temporal podrían pasar de estar protegidos a ser especie cinegética.

\section{Situación actual}

Una idea aceptada en la comunidad científica en general, es la que, por ejemplo, señala el historiador Jürgen Osterhammel cuando dice que "las causas que hacen aparición en un lugar dado pueden tener efectos en un rincón remoto del planeta" 78 . Esta idea, compartida por la comunidad científica y, cada vez más, por buena parte de la sociedad, debería considerarse a la hora de establecer reglas que juegan con el futuro de la biodiversidad y, por ende, con el futuro de la Humanidad.

Lo que pasa al norte del río Duero tiene efectos al sur del río Duero; es una realidad irrefutable. Los lobos que se matan al norte del río Duero tienen efecto sobre los lobos que se protegen al sur del río Duero. Recordemos que la Ley 42/2007, de 13 de diciembre, del Patrimonio Natural y la Biodiversidad, establece que el lobo es especie protegida al sur del río Duero y, al norte, especie cinegética.

La biodiversidad no entiende de accidentes geográficos; es un bien cada vez más escaso, y necesita de una protección integral, no sesgada, para ser efectiva. Incrementar los esfuerzos para la protección de la fauna silvestre en los territorios donde aún se conserva debería ser prioritario, independientemente de otras consideraciones.

\footnotetext{
${ }_{74}^{74}$ Estrategia para la conservación y la gestión del lobo (Canis lupus) en España, Grupo de Trabajo del Lobo, (Madrid, 2006).

75 Según últimos censos oficiales (2012-2014) se podrían superar escasamente los 2.000 ejemplares. Fuente: Ministerio para la Transición Ecológica y Reto Demográfico.

${ }^{76}$ Sastre, N., Vilà, C., Salinas, M., Gologov V.V., Urios, V., Sánchez, A., Francino, O., Ramírez, O., Signatures of demographic bottlenecks in European wolf populations, en Conservation Genetics, 12 (2011), 701-712.

${ }^{77}$ Un cuello de botella es un proceso demográfico que sufre una especie cuando experimenta una drástica reducción del tamaño de su población, ya sea por causas naturales o por causas antrópicas (caza excesiva, pérdida de hábitat...). Sus principales efectos genéticos son pérdida de variabilidad genética y aumento de la consanguinidad, disminuyendo la capacidad adaptativa de la población y por lo tanto aumentando el riesgo de extinción de la especie.

Vid.:https://intranet.uab.es/servlet/Satellite?cid=1096481466568\&pagename=UABDivulga\%2FPage\%2FTemplatePageDetallArticl eInvestigar\&param1 $=1320909593336$

${ }^{78}$ Osterhammel, J., El vuelo del águila, (Barcelona 2018), 206.
} 
No obstante, hay intereses sectoriales, como el ganadero, que deben atenderse, no para que la protección de la fauna silvestre sea menor, sino para que los problemas derivados de ella no ocasionen perjuicios no deseados. Es necesaria la implicación de todos los agentes interesados en el tema para lograr soluciones consensuadas que blinden para siempre la necesaria protección del lobo. Las continuas críticas cruzadas entre unos y otros no ayudan en el cumplimiento del principio de "indispensable solidaridad colectiva" que aconseja el art. 45.2 de la Constitución de 1978 para lograr una defensa y restauración efectiva del medio ambiente.

\subsection{El mundo rural y el lobo}

Las comunidades rurales con una economía basada en la explotación de la ganadería extensiva, en su mayoría, siguen percibiendo al lobo como un problema. En estas comunidades conviven dos visiones distintas. Creo oportuno reproducir unas frases recogidas en una publicación local de Zamora ${ }^{79}$ para describir esas dos percepciones que subyacen en la gente que ha coexistido con el lobo. Una primera, negativa:

Yo he visto muchos lobos, muchísimos, por desgracia he visto muchos. (...) Con 80 años....”la madre que los parió". Antes había más lobos que demonios. Nosotros vivíamos de la ganadería. Aquí toda la vida se sacaba el ganado del pueblo junto, por un lado las ovejas y por otro las cabras. Teníamos 2 pastores. A veces fallaban los pastores y nos tocaba a los vecinos. Yo estuve un año con el ganado. Solo en una ocasión mató siete ovejas mías. Mató más de 50 cabezas. Se le extraviaron a la pastora. Se le separó el rebaño, (...) El pastor es el que hace todo, porque ellos vienen vigilando, vigilando, hacen una encombradica y ahí es cuando atacan. (...) El lobo enfrentarse al hombre nunca. Estuve mucho con el ganado y enfrentarse a nosotros nunca. ${ }^{80}$

Si analizamos su contenido, vemos que los problemas son de índole económica (pérdida de cabezas de ganado), pero también de gestión ineficiente, como cuando faltan los pastores profesionales para la guarda. Por otra parte, tampoco se percibe al lobo como un serio problema para la integridad física de los humanos.

Una segunda percepción de la población rural es la que entiende que puede haber una coexistencia pacífica con el lobo:

Yo soy partidario, además me haría ilusión, que tuviéramos lobos como había antes, pero también sería partidario de que estas cosas se hicieran como hay que hacerlas. El que tiene ganado y vive de ganado, es justo que esté en contra del lobo así que hay que ayudarle. Aunque yo estuve con el ganado, me atrevería a perdonar todas esas cosas que hacen los lobos, porque,...a mí me hicieron mucha compañía. Es verdad que me hacían compañía, siempre estábamos al tanto en el monte que si a lo mejor te saltaba por allí, por donde menos te esperabas, te saltaba allí, bueno, lo espantabas y se marchaba, a lo mejor al poco rato, volvía. Tuve días de salirme hasta tres o cuatro veces, seguramente que sería el mismo, o los mismos. Siempre se veían en manadas, era raro ver un lobo sólo. ${ }^{81}$

De estas percepciones contrapuestas, no obstante, se extrae una misma conclusión: ambas coinciden en la abundancia de lobos en tiempos no muy lejanos. Y si aceptamos esta percepción compartida como cierta, ¿cómo puede ser que con la reducción de la población de lobos, admitida por todos, siga aún vigente el discurso de que el lobo es uno de los mayores problemas para la ganadería extensiva?

Algo va cambiando en el seno de esa sociedad rural, y el lobo ya no se percibe como el mayor problema para sus cabañas. Como ya apuntamos antes, las políticas agrarias de las distintas administraciones públicas y de la Unión Europea pueden ser mucho más lesivas para los intereses de esas comunidades que el lobo. También los intereses de los intermediarios en el proceso de comercialización de los productos ganaderos pueden ser mucho más nefastos para la subsistencia de estas comunidades rurales ganaderas que la coexistencia con el lobo.

Algunos ganaderos de pequeñas explotaciones empiezan a cambiar esa percepción del lobo como alimaña, y están empezando a considerar que, adoptando una serie de medidas preventivas, se puede convivir con el lobo ${ }^{82}$. Aceptan que su actividad puede coexistir con el lobo, y empiezan a sentirlo como algo suyo; y eso es bueno para la biodiversidad y, por tanto, para toda la sociedad.

\footnotetext{
${ }^{79}$ Del Riego Celada, L., Galhano Alves, J.P., Contos y cuentos de lobos. Recorrido por los relatos loberos de Sanabria y Tras os Montes, (Zamora 2006).

${ }^{80}$ Del Riego Celada, L., Galhano Alves, J.P., op. cit., 16.

${ }^{81}$ Ibid., 16.

${ }^{82}$ Videos sobre el tema, bajo el lema "En tierra de todos", en web WWF: https://www.youtube.com/embed/-i1vUK2UUxY. 
Es verdad que los conflictos en el sector ganadero aumentan en los lugares donde el lobo reaparece, y eso se debe a que este sector no está adaptado a su presencia. Para frenar esos conflictos, lo más adecuado es la prevención y protección del ganado: "Desde tiempos antiguos los pastores confían la defensa de sus rebaños a los perros más fuertes. Seguramente de la selección que impone tal menester provienen los mastines -perros formidables y de gran tamaño- que, armados de las inexpugnables carlancas, consiguen enfrentarse con éxito al lobo" 83 . Es decir, volver a la prevención que durante siglos tomaron en consideración los ganaderos peninsulares.

Los problemas del sector ganadero no se solucionan matando lobos. El establecimiento de medidas económicas suficientes para reparar los daños que los lobos ocasionen a las cabañas, la prevención mediante la implantación de medidas de protección del ganado, con ayudas desde las distintas administraciones públicas, o la formación de las gentes del sector ganadero en relación con la etología de la especie, son acciones que pueden mejorar esa coexistencia necesaria.

\subsection{Actividades cinegéticas}

La caza es un tema polémico con intereses contrapuestos: titulares de acotados, dueños de terrenos de caza y agricultores, cazadores, ecologistas, etc. Para practicar la caza, es requisito indispensable obtener una licencia, para asegurar una cierta aptitud cinegética. No obstante, “... la realidad demuestra que se producen toda clase de abusos, aparte de la generalización del furtivismo en sus más distintas formas" ${ }^{" 4}$.

Cazar, según el Diccionario de la Lengua Española de la Real Academia Española, es "buscar o perseguir aves, fieras y otras muchas clases de animales para cobrarlos o matarlos". Según la Federación Española de Caza, la acción de cazar consiste en "una serie de actos que se realizan con la intención de capturar, viva o muerta, una pieza de caza"; el cazador pretende, quiere o desea dar muerte a dicha pieza de caza. Puede afirmarse, sin que suponga un tema de discusión, que la caza es una actividad lúdica cuya finalidad es la muerte de animales de la fauna silvestre. En la actualidad nadie tiene la necesidad de cazar para subsistir, al menos en este país, y la caza se ha convertido, simplemente, en un negocio económico. Conviene recordar que, a lo largo de la historia, las actividades económicas van cambiando a tenor de muchos factores, y que el resultado no suele ser el colapso de la economía o de la sociedad en la que se producen.

Un aspecto discutido, en relación con la caza, es su consideración como deporte. Pueden encontrarse multitud de opiniones a favor y en contra. La normativa deportiva se decanta por considerarlo un deporte; así, el Consejo Superior de Deportes reconoce a la Real Federación Española de Caza como entidad deportiva. No obstante, el empeño en justificarla como deporte no esconde una realidad plausible en la mayoría de las sociedades actuales, que puede constatarse con un ejemplo. Supongamos que se realizara una propuesta a los organismos internacionales olímpicos sobre si debería incluirse el tiro al pichón o la caza de conejos con perros, por poner algunos ejemplos, como deporte olímpico; la respuesta más probable sería no.

La mayoría de las sociedades, a lo largo de los últimos decenios, han ido cambiando la manera de entender su relación con la naturaleza, y ciertas pretensiones del sector cinegético no pueden aceptarse como válidas. No obstante, competiciones que sí podrían considerarse deporte, reconocidas por la Federación Española de Caza, son las denominadas "field target" ${ }^{85}$ o "compak sporting" ${ }^{86}$, ambas sin el objetivo de matar a un animal. Reconocer la caza como deporte, por parte de los poderes públicos, tiene seguramente un trasfondo económico. Así, con esta consideración, las federaciones de caza tienen acceso a subvenciones económicas de cierta importancia. Lo cierto es que la caza no es propiamente un deporte, ni un arte; simplemente es caza, un concepto con entidad propia, nacido y desarrollado mucho antes que cualquier deporte.

Actualmente, algunos cazadores piensan, en relación con el ecologismo, lo que un cazador expone en una revista de caza de tirada estatal que se publicaba en junio de 2020:

Si Félix Rodríguez de la Fuente estuviese entre nosotros todo sería distinto, no estaría de acuerdo con la humanización de los animales. Estos payasos animalistas no existirían, pues Félix los habría barrido. (...) Si este gran naturalista y ecologista no hubiese desaparecido ninguno de estos movimientos habría asomado la cabeza. También a los cazadores nos habría puesto en nuestro sitio denunciando todas las

\footnotetext{
${ }^{83}$ Rodríguez, F., op. cit., 26.

${ }^{84}$ Tamames, R., op. cit., 189.

${ }^{85}$ Esta modalidad, reconocida por la Federación Española de Caza como un tipo de competición, nace como simulación de la caza y constituye una alternativa a la misma. La competición se desarrolla con carabinas de aire comprimido y los blancos son siluetas metálicas cuya forma simula especies cinegéticas colocadas en su entorno natural.

${ }^{86}$ Competición reconocida por la Federación Española de Caza, practicada en campos de reducidas dimensiones y con máquinas automatizadas que lanzan platos de arcilla.
} 
tropelías que se han ido cometiendo. En pocas palabras, nuestra España natural no sería la misma si el Dr. Rodríguez de la Fuente estuviera entre nosotros. Un verdadero ecologista sabe proteger la naturaleza y para esto hay que equilibrar las poblaciones evitar pandemias y desequilibrios entre unas especies y otras. Esto sólo lo puede hacer el cazador con responsabilidad y respeto a la naturaleza. ${ }^{87}$

No es el momento de analizar concienzudamente el contenido del artículo. No obstante, el articulista tiene razón al decir que Félix Rodríguez no hubiera estado de acuerdo con la humanización de los animales, pero esa tampoco es la pretensión de la mayoría de los movimientos sociales a favor de la conservación de la fauna silvestre. Puede llevar razón en que hay "buenos" cazadores, y que para el Dr. Rodríguez de la Fuente tal vez serían los que tratan con dignidad la muerte del animal y que nunca darían caza a especies amenazadas o en peligro de extinción. Ahora bien, lo que no aceptaría el eminente naturalista es que el cazador es el elemento equilibrador de los ecosistemas, de las especies silvestres. El Dr. Rodríguez de la Fuente se implicó personalmente en la conservación del lobo y fue, tal vez, el que posibilitó la supervivencia del lobo en la Península Ibérica en la década de los años setenta del siglo pasado.

Por citar algún hecho que demuestre el efecto de la caza en el equilibrio de las especies, puede resultar interesante el tema del corzo como pieza importante dentro de la dieta del lobo: “... éste no ha podido poner en peligro la población de tales cérvidos, pues, tal como hemos podido comprobar durante varios años, los lobos fracasan, aproximadamente, en siete ataques de cada ocho contra los corzos. Éstos, allí donde han desaparecido, no han estado mediatizados por otro factor de extinción que no haya sido la excesiva presión cinegética humana." 88

En esa misma revista, una carta de su director afirma que “... la crisis del coronavirus ha hecho evidente la necesidad de cazar. Toda la sociedad ha comprendido que el papel de los cazadores en la regulación de las especies es fundamental. Pero ahí no acaba el servicio que nuestra actividad ofrece al país. (...) Los cazadores creamos riqueza, fijamos población..." ${ }^{89}$. Aparte de la primera y segunda afirmación, de difícil aceptación para cualquier mente mínimamente lúcida, en esta carta se refiere al considerable volumen de riqueza económica que genera la caza en España y al empleo que crea, como también al dinero que ahorran las arcas pública en concepto de indemnizaciones por atropellos o por los daños que ocasiona la fauna a las cosechas. Que genera riqueza para unos cuantos es evidente; que los cazadores jueguen un papel fundamental en la regulación de las especies, falso. Como también es discutible que con la caza se fije población humana, salvo que se tomen en consideración porcentajes poblacionales ridículos. Un sector agrario y ganadero viable sí fija población. A buen seguro, estas opiniones no son compartidas por todos los cazadores.

Los argumentos esgrimidos para justificar la caza del lobo, por regla general, están en el daño que causa a la ganadería y la necesidad de regular los ecosistemas naturales y el equilibrio entre las especies. Objetivamente, sólo cabría admitir que, en ocasiones, puede ser necesario el control sobre el lobo, para prevenir daños al ganado en determinadas zonas.

En relación con la opinión del sector cinegético sobre la gestión del lobo, es de indudable interés el trabajo de Lidia García Martín sobre el régimen jurídico para la protección del lobo, en el cual analiza la opinión de los cazadores de Castilla y León, comunidad que aglutina el porcentaje mayor de ejemplares de la especie. Así, mientras que tres de cada cuatro argumentan que el lobo produce graves daños a la ganadería, tan solo un $9 \%$ de los mismos abogan por su erradicación por el motivo citado ${ }^{90}$.

No obstante todo lo anterior, son la caza furtiva y el envenenamiento, dos de los mayores males para la conservación del lobo. Es difícil aventurar las muertes que provocan anualmente ambas acciones en la población de lobos. En demasiadas ocasiones, los furtivos se ensañan con la muerte de estos animales y exponen sus fechorías a la opinión pública con toda su crudeza, en un claro desafío a las autoridades competentes en materia de protección de la fauna silvestre, así como también a las autoridades competentes en materia de seguridad pública. En cuanto al envenenamiento, el problema viene de lejos, y provoca graves daños, no solo en la población lobera, sino en toda la cadena trófica ${ }^{91}$.

Desde un punto de vista más aséptico, Tamames señala que: "En medio de toda una amplia polémica que aflora o se soterra según las coyunturas, y en la que se dan todas las posiciones -desde el abolicionismo de la caza hasta la defensa del cazador como el mejor ecologista- resulta a todas luces necesario que por su transcendencia para la conservación de la naturaleza, y por su importancia económica, se preste mayor y

\footnotetext{
${ }^{87}$ Cuarenta años sin Félix, en Jara y Sedal, n ${ }^{\mathbf{0}} 222$, junio, (Madrid 2020), 66.

${ }^{88}$ Grande del Brío, R., op. cit., 62.

${ }^{89}$ Aún podemos dar más, en Jara y Sedal, nº 222, junio, (Madrid 2020), 3.

${ }^{90}$ García Martín, L., Régimen jurídico para la protección del lobo ibérico y su impacto en el Parque Nacional de Picos de Europa, Trabajo Fin de Grado en Derecho, Universidad de León, 20016, 51.

91 Vid.: El veneno en España. Evolución del envenenamiento de fauna silvestre (1992-2013), publicado por Seo/BirdLife y WWW/Adena en 2016.
} 
renovada atención a la actividad de la caza." $" 92$

Acabar con la caza es algo difícil, ya que mueve un gran volumen de dinero; la denominada caza mayor es un verdadero producto de lujo. Todo ello configura un lobby muy influyente, que también está actuando en contra de la protección del lobo en España. Como dice la Dra. Giménez-Candela, en relación con las asociaciones de cazadores: “... Por mucho que prediquen desde sus foros profesionales que su misión es la conservación de la vida salvaje, la profesionalización y las prácticas éticas en la caza -lo que, por descontado, no pongo en duda-, resulta difícil compaginar tan nobles propósitos con la realidad de satisfacer un capricho lujoso, llevándose por delante animales que han nacido para vivir, no para morir de un balazo."93

En ocasiones, el control del lobo pude ser necesario, y en esto están de acuerdo defensores y detractores de la especie; pero el argumento a veces esgrimido de que es irrelevante que sean abatidos por personal competente y dependiente de las administraciones o por cazadores es falso. Esta segunda opción genera un negocio económico que imposibilita tomar decisiones correctas a favor de la conservación de la especie.

Por mucho que los cazadores sean un colectivo afectado por la toma de decisiones en relación con la gestión y protección del lobo, su objetivo es diáfano: cazar lobos, matar lobos. Por esta razón, el mundo de la caza no puede tener el mismo peso en la ecuación para la conservación del lobo que la que puedan tener otros agentes sociales. Aún así, es imposible no contar con la opinión de este sector que, si actúa con parámetros éticos y ajustándose a la legalidad, puede ser de gran ayuda. Es más, quizá su mayor contribución pueda derivar de la denuncia de actividades relacionadas con el furtivismo, una de las principales lacras para la conservación del lobo ibérico, por su relación con el mundo de la caza y por su conocimiento del terreno. Es reseñable que Lidia García, analizando la actitud de los cazadores en relación con el lobo, constate la existencia de una actitud de furtividad en alrededor del $22 \%$ de los cazadores encuestados ${ }^{94}$.

\subsection{Conservacionistas}

El lobo cuenta, desde hace tiempo, con un agente social implicado en su preservación: las organizaciones no gubernamentales ecologistas, las asociaciones en defensa de la fauna silvestre y del lobo, y movimientos animalistas. Eso no quiere decir que todos remen en una misma dirección, aunque el objetivo final sea la conservación de la especie.

Entre las primeras, podemos citar a la organización no gubernamental Word Wildlife Found (WWF), de carácter internacional y con más de medio siglo de actividad. Trabajó para lograr que, en la década de los 70 del siglo pasado, se reconociera el estatus legal del lobo y dejara de considerarse una alimaña. El Dr. Félix Rodríguez de la Fuente estuvo vinculado a la misma, en su implantación en España a través de ADENA (Asociación para la Defensa de la Naturaleza). En los años 80, se implicó en vigilar la correcta aplicación de la Directiva Hábitats de la CEE, defendiendo al lobo para que se convirtiera en especie protegida.

Entre las asociaciones que defienden la fauna silvestre y pretenden la conservación del lobo, apostando por la coexistencia, podemos citar al Fondo para la Protección de los Animales Salvajes (FAPAS), que entre distintas actividades, actualmente coordina en Asturias la realización de un censo de lobos independiente de otras entidades privadas o administraciones públicas, para lograr una mayor objetividad en los resultados, a todas luces inexistente. La ONG Ecologistas en Acción, confederación de múltiples grupos ecologistas, de ámbito estatal, también está implicada en la protección del lobo y en la coexistencia entre actividades humanas y biodiversidad.

También han surgido otras asociaciones cuyo objetivo concreto es la conservación del lobo. Así, podemos citar a la Asociación para la Conservación y Estudio del Lobo Ibérico (ASCEL), que genera conocimiento sobre el lobo para su posterior divulgación, facilitando la coexistencia entre humanos y lobos. En octubre de 2019 solicitó al Ministerio para la Transición Ecológica, la inclusión del lobo en la categoría de especie "vulnerable" en el Catálogo Español de Especies Amenazadas. De lograr ese objetivo, la protección del lobo estaría más cerca de ser una realidad, ilegalizando las gestiones actuales de control de su población por parte de las CCAA y su explotación cinegética.

Otras acciones en internet en defensa del lobo ibérico son: Signatus.org, un servicio web creado para difundir su realidad, y con más de 20 años de recorrido; o también, Amigos del lobo de Sierra Morena, entidad sin ánimo de lucro, fundada en Sevilla en 2014, que entre sus fines se encuentran el estudio y conservación del lobo ibérico, el fomento de la convivencia con el lobo del mundo rural, la educación ambiental o la preservación y divulgación del patrimonio cultural asociado a la especie.

Una ONG de reciente creación, del año 2012, que se ha caracterizado por su marcado activismo, tanto en los medios de comunicación como en los tribunales, ha sido Lobo Marley. Entre sus acciones más

\footnotetext{
92 Tamames, R., op.cit., 190.

${ }^{93}$ Giménez-Candela, T., op. cit., 121.

${ }^{94}$ García Martín, L., op. cit., 50.
} 
singulares podemos destacar su participación en la subasta de los derechos de caza de lobos de la Sierra de la Culebra, para de esta forma salvarles la vida.

Estas asociaciones también interactúan entre sí, aunando esfuerzos en pro de la conservación del lobo. Así, por ejemplo, en el año 2015, ASCEL, Ecologistas en Acción, Lobo Marley y WWF elaboraron un documento conjunto en el que se presentaban propuestas concretas para actuar a favor de la conservación del lobo ibérico, documento que presentaron al arco político español. Este documento, con el título de "12 propuestas para la conservación del lobo"95, proponía lo siguiente:

1. Proteger el lobo ibérico en toda España, a través de la incorporación de la especie al Listado de Especies Silvestres en Régimen de Protección Especial desarrollado por el RD 139/2011.

2. Paralizar de forma inmediata los programas de control de población de la especie.

3. Promover la elaboración de un censo peninsular del lobo ibérico.

4. Elaborar una nueva Estrategia Nacional de Conservación del lobo ibérico, que sirva de base para que posteriormente las CCAA elaboren los correspondientes planes de recuperación o de conservación.

5. Fomentar la coexistencia entre el lobo y la ganadería extensiva.

6. Aplicar un sistema justo de compensaciones al sector agroganadero que esté condicionado a compromisos ambientales.

7. Reducir los efectos negativos de la actividad cinegética sobre el lobo.

8. Promover acciones contra el furtivismo y los envenenamientos.

9. Regular el turismo relacionado con la observación de lobos.

10.Fomentar la educación y concienciación sobre la importancia ecológica de los grandes depredadores, en particular del lobo.

11.Impulsar el desarrollo y aprobación de Planes de Gestión adecuados para las Zonas de Especial Conservación (ZEC) con presencia de lobo.

12.Permitir el abandono de carroñas de ganadería extensiva en el campo.

Analizando las distintas propuestas, puede comprobarse lo acertado de las mismas para asegurar la conservación de la especie, si atendemos a la mayoría de las opiniones expuestas. El objetivo final gira en torno a la declaración del lobo como especie no cinegética y a su protección en todo el estado español, para conservar la biodiversidad y el equilibrio ecológico, fomentando la coexistencia con el mundo rural.

Por último, los movimientos animalistas consolidados vienen a completar el elenco de agentes sociales a favor del lobo. Cabe citar aquí al Partido Animalista Contra el Maltrato Animal (PACMA), que condena la práctica de la caza, actividad que califica como injustificable, y que defiende una relación de convivencia equilibrada entre humanos y animales.

Básicamente, todos estos agentes parten de la idea de que la gestión de la especie no se ha realizado de forma correcta. Nadie puede decir, con garantías, que conoce la situación real del lobo en la península, y es básico para establecer cualquier tipo de gestión. El lobo no puede censarse con facilidad, sino todo lo contrario. Estas organizaciones abogan por la creación de un censo estatal del lobo, en la que participen todas las administraciones, y en la que se utilice una metodología única, basada en criterios científicos.

A nivel europeo, cabe citar al Eurogrupo para los Animales (Eurogroup for Animals), organización no gubernamental con sede en Bruselas. Esta plataforma, lanzada por la Comisión Europea, tiene por objeto garantizar una óptima aplicación de la normativa europea en materia de bienestar animal. Trabaja para garantizar la protección de las especies silvestres en peligro de extinción según la normativa de la UE, defendiendo los actuales niveles de protección frente a lobbies de cazadores y ganaderos contrarios a ello, así como también para mejorar la conservación de especies protegidas.

Cabe decir, no obstante, que no todos enfocan el problema desde el mismo prisma. Unos son conservacionistas, y pretenden salvar al lobo de la extinción y apuntalar su población de cara al futuro; otros querrían que el lobo volviera a ocupar toda la Península Ibérica. Así, es lógico que existan entre ellos algunas discrepancias, sobre todo en cuanto a las soluciones que plantean.

\subsection{Poderes públicos y justicia}

Los poderes públicos son responsables directos de las normas que regulan los ámbitos que rodean al lobo. Son responsables, en sus dos vertientes, legislativa y ejecutiva, de la política agraria y ganadera, de la política forestal, de la protección de los espacios naturales, de la protección y conservación de la vida silvestre,

\footnotetext{
95 Vid.: https://www.wwf.es/?37000/12-propuestas-para-la-conservacin-del-lobo
}

164 Derecho Animal. Forum of Animal Law Studies, vol. 12/2 
de la regulación de la caza,...; así como también de que las bases y principios reguladores de estas políticas se interpreten según el espíritu de las leyes, no según intereses partidistas, sectarios y cortoplacistas.

Tamames, por poner un ejemplo, asevera que:

... a largo plazo, la política económica a seguir en este país tan desprovisto de masas forestales como lo es el nuestro, no puede consistir más que en la expansión y la restauración del bosque. Los planes de expansión y restauración forestales se diferencian de los demás por el largo plazo de su realización y por la lentitud con que, en general, remuneran el trabajo acumulado. Por ello, su ejecución no puede tener un interés inmediato y positivo más que para los organismos públicos $\mathrm{y}$, fundamentalmente, para el Estado. ${ }^{96}$

Excede de las posibilidades de nuestro trabajo entrar a analizar la legislación forestal, tanto estatal como comunitaria, pero seguramente sería enriquecedor en relación con la evolución del estado de salud de la población del lobo.

El mismo autor, acabando la última década del siglo pasado, manifiesta una realidad que debería ser considerada por todos los sectores implicados: "Sin embargo, no todo es legislar y reglamentar. En realidad, lo que de esta nueva orientación comunitaria se derive, dependerá de si se acoge por el espíritu emprendedor de los europeos, tanto a nivel público como privado; en el sentido de que se sepan aprovechar las importantes subvenciones que se conceden por la comentada legislación comunitaria, para reverdecer una Europa quemada en el Norte por la lluvia acida, y en el Sur por los incendios forestales." ${ }^{\text {"97 }}$ Lamentablemente, no parece que se haya aprovechado de manera eficaz.

En la actualidad, tampoco parece existir un consenso unánime en las medidas políticas que se adoptan en materias que, indirectamente, afectarán al lobo. En octubre de 2020, se ha llegado a un acuerdo político entre los Estados comunitarios para la futura PAC 2021-2027, y éste ya ha sido calificado como decepcionante por algunas ONG ecologistas. Así, entre otras cuestiones, critican el continuismo en la contabilización como presupuesto para objetivos ambientales, a ayudas que no establecen condiciones suficientes para garantizar una gestión ambiental adecuada ${ }^{98}$.

Por desgracia, y como hemos ido esbozando en la primera parte de este trabajo, medio ambiente y caza se interrelación con demasiada facilidad. Y aquí entran en juego los poderes públicos. Por poner un ejemplo, la Ley 13/2013, de 23 de diciembre, de caza de Galicia, en su exposición de motivos dice lo siguiente: “... dado que la superficie cinegética de Galicia comprende más del $80 \%$ del territorio gallego, la caza cobra un singular protagonismo, necesario en el control de determinadas poblaciones de especies silvestres para lograr un equilibrio ecológico y fundamental en el normal desarrollo de los ecosistemas naturales. La actividad cinegética trasciende de su condición deportiva y lúdica y gana peso en su función social y ambiental." Sería interesante preguntarse si el legislador ha considerado suficientemente el contenido de la Ley 42/2007, de 13 de diciembre, del Patrimonio Natural y de la Biodiversidad, que estable el régimen jurídico básico de la conservación, uso sostenible, mejora y restauración del patrimonio natural y de la biodiversidad -en aplicación del art. 45.2 de la CE-, en la elaboración de la citada ley de caza. En especial, los principios que inspiran la ley, como el apartado a) del art. 2, cuando habla del mantenimiento de los procesos ecológicos esenciales, o en el apartado g) del mismo artículo, sobre la precaución en las intervenciones que puedan afectar a especies silvestres. La prioridad de la conservación del medio ambiente y de la fauna silvestre frente a la caza debería ser una realidad. En estos casos, los poderes públicos actúan con cierta arbitrariedad.

Para introducir mínimamente el tema de la justicia, recogemos unas palabras del Dr. Enrique Alonso:

Es curioso cómo los juristas como grupo social "eligen" de entre las normas, tanto de las importantes como de las nimias, las que en realidad se ajustan mejor a sus propios valores subjetivos (en realidad a su ideología), rechazando el principio democrático esencial de que es la comunidad representada por sus poderes legítimos, y no ellos mismos, la fuente del Derecho en una democracia constitucional. El desconocimiento del texto mismo del artículo 13 TFUE puede considerarse, desde la perspectiva de la sociología, como un ejemplo claro de esta "ceguera" 99 .

Estas palabras podrían expresar la realidad de algunas sentencias referidas a la protección y a la gestión

\footnotetext{
${ }^{96}$ Tamames, R., op. cit., 193.

${ }^{97}$ Ibid., 202.

98 Vid.: https://www.europapress.es/asturias/asturias-rural-00671/noticia-wwf-seo-birdlife-tildan-decepcionante-nueva-pac-porqueda-espalda-pacto-verde-europeo-20201021 191521.html

99 Alonso García, E., El artículo 13 del Tratado de Funcionamiento de la Unión Europea: Los animales como seres sensibles (sentientes) a la luz de la jurisprudencia del Tribunal de Justicia de la Unión Europea, en Animales y Derecho (Valencia 2015 ), 19.
} 
y caza del lobo. No obstante, también es verdad que, por ejemplo, la Sentencia No 1458/2019, del Tribunal Superior de Justicia de Castilla y León, sirve de apoyo a la causa conservacionista. Esto quiere decir que empieza a haber un movimiento a favor de la conservación en una parte de los agentes jurídicos.

La protección jurídica de la fauna silvestre, en el ámbito penal, podemos encontrarla vinculada al medio ambiente. Es el supuesto contemplado en el art. 330 del Código Penal, cuando señala el daño grave a alguno de los elementos de un espacio natural protegido ${ }^{100}$. De forma expresa, el Capítulo IV del Título XVI del CP, tipifica los delitos relativos a la protección de la fauna silvestre ${ }^{101}$. Excede la intencionalidad de nuestro trabajo, pero no deja de ser diáfana la exposición que realiza la Dra. Esther Hava sobre las diversas interpretaciones que la jurisprudencia ha podido utilizar en relación con los delitos relativos a la fauna silvestre ${ }^{102}$

La inclusión en el CP de algún precepto que impusiera penas por la captura y/o muerte de los animales silvestres acompañadas de maltrato injustificado, o de cualquier animal de la categoría que sea (doméstico, domesticable,...) que vivan en estado salvaje, podría ser un medio útil para penalizar el trato cruel que reciben en demasiadas ocasiones. Es evidente que un cazador no va a sedar al animal que pretende matar, pero ello no le exime de su obligación moral de reducir, en la medida de lo posible, el dolor del animal en su proceso de extracción.

La muerte de estos animales merece la misma consideración que la dada al elenco establecido en el art. 337.1 del $\mathrm{CP}^{103}$. Y eso por dos motivos básicos: en primer lugar, porque la comunidad científica ha declarado que los animales no humanos son seres sintientes ${ }^{104}$, y no distingue entre animales no humanos silvestres o no silvestres; y en segundo lugar, por la idea de la dignidad intrínseca de los animales, tanto si procede de una afirmación religiosa (como por ejemplo, la dignidad que para el calvinismo tienen todas las criaturas) o de una afirmación filosófica (sobre la consideración moral de los animales no humanos). Esta última idea parece que está calando en parte de los humanos que practican la actividad cinegética; así, han adoptado en su lenguaje la palabra ética, pero desgraciadamente, este concepto no se recoge de forma expresa en el llamado código ético del cazador ${ }^{105}$.

La extracción de animales de sus hábitats, es decir, la muerte de los animales silvestres por parte de los humanos mediante armas de fuego y otros medios, debido a la práctica de un supuesto deporte, como mínimo debería realizarse de la manera menos cruenta posible para el animal. Además, el trato al cuerpo sin vida del animal debería ser adecuado al supuesto código ético del cazador, es decir, respetando su dignidad. Si estos parámetros de trato animal se dispensan a los denominados animales domésticos, no existe ninguna justificación para que no los reciban, de la misma manera, los animales silvestres. No obstante, el Dr. David Favre ya expuso la dificultad que presenta este tipo de argumentación para nuestra sociedad actual ${ }^{106}$, debido a la dificultad de dar un cierto trato de bienestar animal a la muerte de la fauna silvestre en su propio hábitat.

\section{Estatus jurídico del lobo en España}

El 15 de octubre de 1978, en París, se proclamó en la sede de la UNESCO la Declaración Universal de los Derechos de los Animales; una declaración sin valor jurídico pero con un alto contenido ético. En su artículo 4 se dice que "...todo animal perteneciente a una especie salvaje, tiene derecho a vivir libre en su propio ambiente natural, terrestre, aéreo o acuático y a reproducirse, y que toda privación de libertad, incluso aquella que tenga fines educativos, es contraria a este derecho." ${ }^{107}$ En el año 2011 se propuso una actualización de la citada declaración, y en la nueva redacción del citado artículo se dice que los “....animales salvajes tienen derecho a vivir y reproducirse en libertad en su propio entorno natural, y que la privación prolongada de la libertad de los animales salvajes, la caza y la pesca practicada como pasatiempo, así como cualquier uso de animales salvajes, son contrarios a este derecho fundamental". Si en algún momento este contenido alcanza valor jurídico, tal vez ya no sea una acuciante necesidad analizar vías jurídicas para proteger la biodiversidad del planeta, de la que la fauna silvestre es su mayor activo.

No podemos hablar de la existencia de un derecho internacional para la protección de la fauna silvestre, sino, más bien, de organizaciones internacionales que analizan el estado de conservación de la naturaleza a

\footnotetext{
${ }^{100}$ Art. 330 del Código Penal español (Ley Orgánica 10/1995, de 23 de noviembre, del Código Penal).

101 Artículos 333 al 336 del CP.

102 Hava García, E., La tutela penal de los animales, (Valencia, 2009), 17-22.

103 Se incluyen los animales domésticos o amansados, los animales que habitualmente están domesticados, los que temporal o permanentemente viven bajo control humano, y cualquier animal que no viva en estado salvaje.

104 Mención especial merece el documento "The Cambridge Declaration of Consciousness", de 2012; Vid. http://fcmconference.org/img/CambridgeDeclarationOnConsciousness.pdf

105 Vid.: https://www.fecaza.com/caza/requisitos-del-cazador.

106 Favre, D., Humane Treatment of Wildlife, en Animal Suffering: From Science to Law, (Toronto, 2013).

107 Vid.: https://derechoanimal.info/sites/default/files/legacyfiles/bbdd/Documentos/1286.pdf

166 Derecho Animal. Forum of Animal Law Studies, vol. 12/2
} 
nivel global y ofrecen posibles soluciones para su mejor conservación. Es el caso de la Unión Internacional para la Conservación de la Naturaleza (UICN) ${ }^{108}$, que cuenta con multitud de organizaciones, gubernamentales y no gubernamentales, de más de 160 países, y de un gran colectivo de expertos en materias de conservación y desarrollo sostenible. Creada en Fontainebleau en 1948, a nivel internacional, se reconoce el trabajo y los estándares internacionales de calidad que dicha organización establece para la conservación de la naturaleza, pero no supone un corpus jurídico al que se pueda apelar ante los tribunales. No por ello deja de ser esencial en la tarea de la defensa de la conservación de la naturaleza, y es de especial relevancia su Lista Roja de Especies Amenazadas, que supone el indicador más fiable del riesgo global de extinción de especies.

Tampoco puede olvidarse la implicación de la UICN en la elaboración de convenciones internacionales, como la Convención sobre el Comercio Internacional de Especies Amenazadas de Fauna y Flora Silvestres (CITES), de 1974, o el Convenio sobre la Diversidad Biológica (1992). Estos acuerdos internacionales son de una indudable valía, como la CITES ${ }^{109}$, que supone un instrumento valioso para que el comercio internacional de especímenes de animales silvestres no amenace la supervivencia de las mismas. O el Convenio de Diversidad Biológica ${ }^{110}$, que bajo el paraguas de la ONU, pretende, entre sus objetivos, la conservación y el uso sostenible de la diversidad biológica. Todo ello viene a configurar un abanico de instrumentos, algunos de carácter jurídico, pero no suponen un corpus jurídico suficiente: no existe un tratado internacional para la protección de la fauna silvestre. Por esta razón, debemos centrarnos en mayor medida en el derecho comunitario y en el de cada estado de la Unión Europea para avanzar en la conservación del lobo.

No pretendemos en los apartados siguientes hacer una exposición detallada de todo el contenido jurídico que versa sobre esta especie, objetivo que demandaría mucha más extensión que la de este trabajo, pero sí ofrecer una visión general de su marco legal y algunas cuestiones que resultan de indudable interés para profundizar en una conservación más eficaz de la especie.

\section{Legislación de la Unión Europea en materia de protección de la vida silvestre}

El Convenio relativo a la conservación de la vida silvestre y del medio natural de Europa (Berna 1979), tiene como objetivo la conservación de la flora y de la fauna silvestre y sus hábitats naturales, con especial atención a las especies amenazadas de extinción y vulnerables. El convenio fue aprobado en nombre de la Comunidad Económica Europea por Decisión del Consejo, de 3 de diciembre de 1981. En él, se establece una distinción entre especies de fauna silvestre estrictamente protegida (Anejo II) y especies de fauna protegida (Anejo III). La especie Canis lupus se incluye como especie estrictamente protegida.

En su primer considerando, el Convenio de Berna expone que para la consecución de una política de medio ambiente "...es especialmente necesario velar por la buena gestión de los recursos y del medio natural y evitar toda explotación de éstos que entrañe un daño apreciable para el equilibrio ecológico". La especie Canis lupus se encuentra en la cúspide del triángulo en el cual se suele representar la cadena trófica; por tanto, su desaparición en los biotopos que ocupaba supone un daño mayúsculo al equilibrio ecológico necesario y, por ende, a los principios que rigen el Convenio de Berna. En otras palabras, la gestión de los recursos y del medio natural no puede suponer un daño apreciable al equilibrio ecológico. Por eso, debería protegerse este equilibrio con la conservación de las especies reguladoras del mismo, como es el caso del lobo.

España aprobó y ratificó dicho convenio, mediante Instrumento de ratificación de 13 de mayo de 1986. Al amparo del art. 22 del convenio, referente a la posibilidad de que cualquier Estado pudiera formular reservas con respecto a determinadas especies enumeradas en los Anejos I al III, el gobierno español hizo reserva de la especie Canis lupus (incluida en el Anejo II) como "Especies de fauna estrictamente protegidas", pasando a considerarse por España como "Especies de fauna protegidas" (con la protección prevista en las especies incluidas en el Anejo III). Con esta reserva se privaba el lobo ibérico de una protección legislativa estricta con la que contaba el lobo europeo. Sin embargo, ello no es óbice para desatender las consideraciones generales del Convenio, entre ellas la señalada en el párrafo anterior sobre la necesidad de evitar daños apreciables en el equilibrio ecológico.

En otro orden de cosas, el art. 3.3 del citado Convenio hacía referencia a que las Partes contratantes fomentaran la educación y la difusión de informaciones generales acerca de la necesidad de conservar las especies de la fauna silvestre. La realidad demuestra que esta función educativa, en relación con la especie que nos atañe, la realizan en mucha mayor medida las ONG conservacionistas que los poderes públicos, al menos a nivel de medios de comunicación de masas. Este principio a seguir sobre el fomento de la educación y la difusión de la conservación de la fauna silvestre también la recoge la Directiva Hábitats, de la que

108 Vid.: https://www.iucn.org/es

${ }^{109}$ Vid.: https://www.cites.org/eng

${ }^{110}$ Vid.: https://www.cbd.int/ 
hablaremos a continuación, que en uno de sus considerandos señala “...que la educación y la información general relativas a los objetivos de la presente Directiva son indispensables para garantizar su aplicación efectiva".

El hito en la materia de protección de la naturaleza, en el ámbito de la Unión Europea, se establece con la Directiva 92/43/CEE del Consejo, de 21 de mayo de 1992, relativa a la conservación de los hábitats naturales y de la fauna y flora silvestres, conocida como Directiva Hábitats. Esta norma comunitaria "tiene por objeto contribuir a garantizar la biodiversidad mediante la conservación de los hábitats naturales y de la fauna y flora silvestres en el territorio europeo de los Estados miembros al que se aplica el Tratado". ${ }^{11}$ Tiene como objetivo, por tanto, favorecer el mantenimiento de la biodiversidad, pero atendiendo también a las exigencias económicas, sociales, culturales y regionales y locales ${ }^{112}$. Con estos aspectos a considerar, parece obvio que el constituyente europeo, entre otros intereses, pretende salvaguardar al sector cinegético.

En su art. 2.1 señala que "las medidas que se adopten en virtud de la presente Directiva tendrán como finalidad el mantenimiento o el restablecimiento, en un estado de conservación favorable, de los hábitats naturales y de las especies silvestres de la fauna y de la flora de interés comunitario". Mantenimiento, que debe referirse a los hábitats y a sus especies donde aún se conservan; restablecimiento, que debe entenderse como volver a establecer especies en hábitats donde desaparecieron, ponerlas en el estado que tenían antes esas especies ${ }^{113}$. Como es fácil suponer, la realidad demuestra que este precepto se incumple taxativamente. En varios decenios la población del lobo ibérico ha permanecido en el mismo lugar, con excepciones numéricamente despreciables, sin alcanzar hábitats en los que tiempo atrás había ocupado.

En su art. 12.1, habla de la obligación de los Estados miembros de desarrollar un sistema de protección riguroso de las especies del Anexo IV, letra a), en la que se incluye el Canis lupus. En el caso de España, solo las poblaciones de lobos al norte del río Duero, que se incluyen en el Anexo V (especies animales de interés comunitario), pueden ser objeto de medidas de gestión.

No obstante, existen límites a esa gestión. Así el art. 14.1 señala que las especies de fauna silvestre del Anexo V, para que puedan ser recogidas de la naturaleza, deben existir en un estado de conservación favorable. Relacionando el contenido de las letras e) e i) del art. 1, se entiende como estado de conservación favorable de una especie, cuando las influencias que actúan sobre la especie no puedan afectar negativamente a la distribución e importancia de sus poblaciones a largo plazo. En relación al lobo, debería ser evidente que sin estudios científicos relevantes sobre su estado de conservación, no debería autorizarse ningún tipo de gestión, sobre todo la explotación cinegética. Así lo corrobora otro de los considerandos, cuando dice que "es indispensable mejorar los conocimientos científicos y técnicos para la aplicación de la presente Directiva, y que conviene, por consiguiente, fomentar la investigación y los trabajos científicos que se requieren a tal efecto". Y son los Estados miembros los obligados a vigilar el estado de conservación de especies y hábitats, según el art. 11 de la norma comunitaria.

La gestión y explotación de especies del Anexo V, entre ellas el lobo ibérico al norte del Duero, se permite a tenor del art. 14, así como la práctica cinegética, si bien respetando la conservación de las poblaciones. Y el art.16.1 posibilita establecer excepciones a lo dispuesto en el art. 12 (protección de especies animales), siendo la letra b) la trasposición a la actualidad de la eterna justificación de la caza de las grandes especies carnívoras europeas: "para evitar daños graves en especial a los cultivos, al ganado,...".

Otro aspecto de indudable interés de la norma comunitaria es la aceptación del carácter transfronterizo del problema de la degradación de hábitats naturales y de especies silvestres amenazadas, recogido en otra de sus consideraciones. Este hecho hace imprescindible la toma de medias a nivel comunitario para una correcta conservación. Y este principio de actuación no se considera suficientemente en la configuración de la protección del lobo en el ordenamiento jurídico español, como se verá más adelante.

Otra consideración de interés que recoge la Directiva Hábitat es que "para garantizar el restablecimiento o el mantenimiento de los hábitats naturales y de las especies de interés comunitario en un estado de conservación favorable, procede designar zonas especiales de conservación a fin de realizar una red ecológica europea coherente...". El art. 3 de la norma cimenta las bases de una red ecológica europea coherente de zonas especiales de conservación (Natura 2000), que deberían suponer corredores para la fauna, para garantizar el mantenimiento y el restablecimiento de un estado de conservación favorable. No parece que la explotación cinegética permita implementar el contenido de la Directiva, sobre todo si se cazan lobos que podrían migrar

\footnotetext{
${ }^{111}$ Art. 2.1 de la Directiva 92/43/CEE del Consejo, de 21 de mayo de 1992, relativa a la conservación de los hábitats naturales y de la fauna y flora silvestres.

112 Art. 2.3, Directiva 92/43/CEE del Consejo.

${ }^{113}$ La falta de certidumbre en la interpretación de preceptos de la Directiva Hábitats hace que el restablecimiento de la especie sea harto complicada. Vid.: López-Bao, J.V., Fleurke, F., Chapron, G., Trouwborst, A., Legal obligations regarding populations on the verge of extinction in Europe: Conservation, Restoration, Recolonization, Reintroduction, Biological Conservation, en Biological Conservation, 227 (2018), 319-325.
} 
hacia territorios de la península con exiguas poblaciones, y ayudar a una cierta mejora genética y a su restablecimiento. Este hecho va en contra del establecimiento de corredores ecológicos para el restablecimiento y mantenimiento de las especies de interés comunitario, que señalábamos anteriormente.

Ciñéndonos a la regulación del Canis lupus en el Anexo II de la Directiva, relativo a las especies animales y vegetales de interés comunitario para cuya conservación es necesario designar zonas especiales de conservación, dice que respecto a las poblaciones españolas, solamente las del sur del Duero se entenderán incluidas en el citado Anexo, al igual que las poblaciones griegas de lobos solo al sur del paralelo 39. Este criterio de distinción para establecer las poblaciones de lobos a proteger de forma rigurosa o no, puede no ser tan banal. Si atendemos al texto de la Directiva, en Grecia sólo se pueden gestionar las poblaciones de lobos por encima del paralelo 39, mientras que en España sólo se pueden gestionar las poblaciones de lobos al norte del río Duero. Por tanto, en el caso español, podría interpretarse que es ilícito cualquier intento de gestionar las poblaciones de lobos al este del río Duero, debiendo considerarse como especie protegida. Supuestamente, esta debe ser la interpretación que pretende dar el legislador, ya que de lo contrario, hubiera utilizado el paralelo pertinente del río Duero.

La Directiva Hábitats obliga a los Estados miembros en cuanto al resultado que debe obtenerse, exigiendo una transposición al ordenamiento jurídico nacional y dejando cierta libertad en cuanto a la forma y los medios de su aplicación.

Aunque de ámbito internacional, también es necesario citar el Convenio sobre Diversidad Biológica ${ }^{114}$, de 1992, tratado internacional que cuenta con la mayoría de los países del mundo como Partes Contratantes. España ratificó dicho Convenio el 21 de diciembre de 1993. Su objetivo básico es la conservación de la diversidad biológica y su uso sostenible. En relación con el ámbito jurídico europeo e internacional, resulta de gran interés el reciente trabajo del Dr. Agustín García Ureta sobre el régimen jurídico aplicable al lobo ${ }^{115}$.

\section{El lobo en el ordenamiento jurídico español: normativa estatal y de las CCAA}

El art. 45 de la Constitución española de 1978 se convierte, desde el punto de vista jurídico, en el fundamento básico para la creación de normativa sobre medio ambiente y biodiversidad. Su encuadre en la $\mathrm{CE}$, jerárquicamente superior a cualquier otra norma, imposibilita normas contrarias a su contenido: es la norma normarum del ordenamiento jurídico español ${ }^{116}$. Así, se convierte en el precepto básico en materia de medio ambiente y biodiversidad, y recoge el derecho a disfrutar de un medio ambiente adecuado y el deber de conservarlo. En su punto 2, dice: "Los poderes públicos velarán por la utilización racional de todos los recursos naturales, con el fin de proteger y mejorar la calidad de la vida y defender y restaurar el medio ambiente, apoyándose en la indispensable solidaridad colectiva." Incluido en el Capítulo Tercero del Título I de la CE, se concibe como uno de los principios rectores de la política social y económica, objetivo a perseguir por los poderes públicos.

En el Capítulo Tercero del texto constitucional se relacionan derechos económicos, sociales y culturales, que configuran el Estado social. Hay que recordar que estos derechos no tienen la misma fuerza normativa y las mismas garantías que los derechos y libertades reconocidos en el Capítulo Segundo del mismo Título, considerados éstos fundamentales. Tanto es así, que los derechos reconocidos en el Capítulo Tercero solo pueden alcanzarse con una acción positiva de los poderes públicos, que "...exige una actividad reguladora, un despliegue de los servicios públicos y una fuerte actividad prestacional (Estado benefactor)" 117 .

La Ley 4/1989, de 27 de marzo, de Conservación de los Espacios Naturales y de la Flora y Fauna Silvestres, supuso la introducción en el ordenamiento jurídico español de los convenios ratificados por el Estado en la década de los ochenta sobre conservación de la naturaleza, así como la derogación de la antigua Ley de Espacios Naturales Protegidos, de 2 de mayo de 1975. Esta ley trasponía al ordenamiento jurídico español las Directivas sobre protección de la fauna y la flora de la CEE.

El art. 149.1.23 $3^{\mathrm{a}}$ de la CE, en su párrafo primero, señala como competencia exclusiva del Estado la "legislación básica sobre protección del medio ambiente, sin perjuicio de las facultades de las Comunidades Autónomas de establecer normas adicionales de protección". Actualmente, el desarrollo normativo del art. 45 del texto constitucional, se plasma con la Ley 42/2007, de 13 de diciembre, del Patrimonio Natural y de la Biodiversidad, que establece el régimen jurídico básico de la conservación, uso sostenible y restauración del patrimonio natural y de la biodiversidad.

\footnotetext{
${ }^{114}$ Convenio de Naciones Unidas, de 1992. Vid.: https://www.cbd.int/doc/legal/cbd-es.pdf

115 García Ureta, A., Consideraciones sobre el Régimen Jurídico de la Unión Europea e Internacional de aplicación al lobo (Canis lupus) y su traslación al Derecho español, en Actualidad Jurídica Ambiental, n. 111, (abril 2021), 1-40. Vid.: https://actualidadjuridicaambiental.com/wp-content/uploads/2021/04/2021-04-05-GarciaUreta-Conservacion-lobo.pdf

${ }^{116}$ Fossas i Espadaler, E., Pérez Francesch, LL., Lliçons de Dret Constitucional, (Barcelona 2019), 24.

117 E. Fossas, J.LL. Pérez, op. cit., 152.
} 
Uno de los principios inspiradores de la Ley 42/2007, y de los más trascendentes, es la preservación de la diversidad biológica y genética de las poblaciones y de las especies. Entre las finalidades más importantes de dicha ley está el detener el ritmo actual de pérdida de diversidad biológica y, en este contexto, en su artículo 54.1, indica que para garantizar la conservación de la biodiversidad que vive en estado silvestre, la Administración General del Estado y las CCAA deberán establecer regímenes específicos de protección para aquellas especies silvestres cuya situación así lo requiera.

Además de las actuaciones de conservación que realicen las administraciones públicas para alcanzar dicha finalidad, la Ley 42/2007, en sus artículos 56 y 58 respectivamente, crea con carácter básico, el Listado de Especies Silvestres en régimen de protección especial (LESPRE) y, en su seno, el Catálogo Español de Especies Amenazadas (CEA). Asimismo, se establecen una serie de efectos protectores para las especies que se incluyan en los citados instrumentos y se establecen dos categorías de clasificación, como son las de especie «vulnerable» $\mathrm{y}$ «en peligro de extinción», distinción que permite establecer prioridades de acción e identificar aquellas especies que necesitan una mayor atención. Finalmente, se prevé el desarrollo reglamentario del Listado, finalidad general a la que responde el Real Decreto 139/2011, de 4 de febrero, para el desarrollo del Listado de Especies Silvestres en Régimen de Protección Especial y del Catálogo Español de Especies Amenazadas. Todo ello en aras a garantizar la conservación de la biodiversidad.

Los art. 7 y el art. 8 de la citada ley prevén un mecanismo de cooperación entre AAPP, la Comisión Estatal para el Patrimonio Natural y la Biodiversidad, así como un órgano de participación pública, denominado Consejo Estatal para el Patrimonio Natural y la Biodiversidad. Por una parte, el Real Decreto 1424/2008, de 14 de agosto, determina la composición y las funciones de la Comisión Estatal para el Patrimonio Natural y la Biodiversidad, donde se dictan las normas que regulan su funcionamiento y se establecen los comités especializados adscritos a la misma. Por otra, el Real Decreto 948/2009, de 5 de junio, determina la composición, las funciones y las normas de funcionamiento del Consejo Estatal para el Patrimonio Natural y la Biodiversidad. Este último es un órgano de participación pública en el ámbito de la conservación y el uso sostenible del patrimonio natural y la biodiversidad, y establece que su composición y funciones se determinarán reglamentariamente, previa consulta con las comunidades autónomas, garantizándose la participación de las organizaciones profesionales, científicas, empresariales, sindicales y ecologistas más representativas.

Obligado por la Directiva Hábitats de la Unión Europea, el lobo se encuadra en el marco jurídico español en el LESPRE, en relación con las poblaciones al sur del Duero, como contempla el RD 139/2011. Por tanto, en aplicación del art. 57.1.b de la Ley 42/2007, queda prohibida “... cualquier actuación hecha con el propósito de darles muerte, capturarlos, perseguirlos o molestarlos, así como la destrucción o deterioro de sus... lugares de reproducción, invernada o reposo", prohibición que se extiende a todas las fases de su ciclo biológico. No obstante, cabe recordar la mala praxis en la trasposición de la normativa comunitaria al ordenamiento estatal, ya que este Reglamento, en su primera redacción, solo incluía al lobo como especie en régimen de protección especial en las CCAA de Andalucía, Castilla-La Mancha y Extremadura ${ }^{118}$.

En el artículo citado, en su apartado 2, se señala el deber de la Administración General del Estado y las CCAA, en sus ámbitos competenciales respectivos, de establecer un sistema de control de capturas o muertes accidentales, con la finalidad de adoptar las medidas necesarias para minimizar sus efectos en las especies incluidas en el LESPRE, caso del lobo en sus poblaciones al sur del Duero.

Las especies incluidas en el CEA, competencia del Ministerio de Medio Ambiente ${ }^{119}$ a propuesta de la Comisión Estatal para el Patrimonio Natural y la Biodiversidad, tienen un nivel de protección superior a las relacionadas en el LESPRE. Su inclusión está motivada por información técnica o científica que así lo aconseje, y establece dos categorías, ya señaladas, especies en peligro de extinción y especies vulnerables. La iniciativa para su inclusión o exclusión, según el art. 58.2 de la ley, puede partir del propio Ministerio y de las CCAA. También se establece la posibilidad de que cualquier ciudadano u organización pueda solicitar la iniciación del procedimiento de inclusión, cambio de categoría o exclusión, acompañada de argumentación técnica o científica ${ }^{120}$.

El art. 59 de la Ley 42/2007 establece aspectos básicos en relación con la protección de las especies incluidas en el CEA, con algunas diferencias entre las especies consideradas "vulnerables" o "en peligro de extinción". Las CCAA son las responsables de elaborar y aprobar planes de conservación y recuperación para

\footnotetext{
${ }^{118}$ Mediante Orden TEC/596/2019, de 8 de abril, por la que se modifica el anexo del RD 139/2011, de 4 de febrero, para el desarrollo del Listado de Especies Silvestres en Régimen de Protección Especial y del Catálogo de Especies Amenazadas, se aplicó correctamente la protección al lobo a la que obligaba la Directiva Hábitats. Se modificó la población referida, siendo a partir de su entrada en vigor "Poblaciones al sur del Duero".

119 Actualmente denominado Ministerio para la Transición Ecológica y el Reto Demográfico (MITECO).

120 ASCEL, en octubre de 2019, ha optado por esta vía para la protección del lobo, solicitando su inclusión en el Catálogo como especie "vulnerable".
}

170 Derecho Animal. Forum of Animal Law Studies, vol. 12/2 
dichas especies. En el supuesto que una especie se encontrará en una situación crítica, el art. 60 regula el procedimiento a seguir para lograr una estrategia eficaz para su conservación, cuyas acciones encaminadas a tal fin tendrían la consideración de interés general.

El art. 61 de la Ley 42/2007 prevé excepciones a las prohibiciones establecidas en el Capítulo I (Conservación in situ de la biodiversidad autóctona silvestre) del Título III (Conservación de la biodiversidad). Entre ellas, y de posible aplicación al lobo, se establece la excepción para prevenir perjuicios importantes al ganado. El procedimiento para la autorización a las excepciones es complejo, priorizando así la conservación de las especies.

Cabe señalar que el CEA no es un documento cerrado; el art. 58.3 de la Ley 42/2007 señala que las CCAA “...podrán establecer catálogos de especies amenazadas, estableciendo, además de las categorías relacionadas en este artículo, otras específicas, determinando las prohibiciones y actuaciones suplementarias que se consideren necesarias para su preservación". Y el mismo artículo, en su punto 4, permite a las CCAA “...incrementar el grado de protección de las especies del Catálogo Español de Especies Amenazadas en sus catálogos autonómicos, incluyéndolas en una categoría superior de amenaza".

El Real Decreto 1274/2011, de 16 de septiembre, por el que se aprueba el Plan estratégico del patrimonio natural y de la biodiversidad 2011-2017, surge también en aplicación de la Ley de Patrimonio Natural y Biodiversidad. Este Plan estratégico supone un instrumento de planificación de la actividad de la Administración General del Estado en la materia. Su objeto es el establecimiento y la definición de objetivos, acciones y criterios que promuevan la conservación, el uso sostenible y la restauración del patrimonio, los recursos naturales terrestres y marinos, la biodiversidad y la geodiversidad.

Todo este marco jurídico se complementa con instrumentos derivados de esta normativa. Así podemos citar al Comité de Flora y Fauna Silvestres, en el seno de la Comisión Estatal para el Patrimonio Natural y la Biodiversidad, e integrado por representantes del MITECO y de las CCAA, que es un instrumento para la coordinación de actuaciones en materia de conservación de especies a nivel estatal, como también de las derivadas del cumplimiento de la normativa comunitaria y los convenios internacionales. O también, las estrategias de conservación para las especies más amenazadas, herramienta fundamental para coordinar la conservación de especies amenazadas presentes en más de una comunidad autónoma.

En relación con el lobo, la Conferencia Sectorial de Medio Ambiente aprobó, en 2005, la Estrategia Nacional de Conservación y Gestión del lobo, documento ya mencionado en este trabajo al abordar la población y distribución del lobo. Esta estrategia tuvo el asesoramiento técnico del Grupo de Trabajo del Lobo, dependiente del Comité de Flora y Fauna Silvestres, creado para analizar la conservación de la especie y las problemáticas que la envuelven.

En el entramado organizativo expuesto se observa la existencia de canales de comunicación y coordinación entre las distintas AAPP, así como entre los distintos agentes interesados en el tema. Pero el trabajo derivado de ello no debe ser solo puntual, sino más bien continuado en el tiempo. Así, por ejemplo, el art. 9 del RD 139/2011, de 4 de febrero, para el desarrollo del Listado de Especies Silvestres en Régimen de Protección Especial y del Catálogo Español de Especies Amenazadas, regula la evaluación periódica del estado de conservación. Habla de la obligación de realizar un seguimiento específico por parte de las CCAA en sus ámbitos territoriales para evaluar el estado de conservación de las especies; y si la especie en cuestión se localiza en más de una CCAA, el Ministerio competente y las CCAA adoptarán los mecanismos de coordinación que procedan, a través de la Comisión Estatal para el Patrimonio Natural y Biodiversidad. La evaluación de las especies se efectuará al menos cada seis años para las "especies vulnerables" y cada tres años para las especies "en peligro de extinción".

Podríamos extendernos en el análisis de la normativa estatal, pero creemos que el contenido expuesto ofrece una visión aproximada del marco jurídico que envuelve la protección de especies silvestres, como es el caso del lobo. Existen otras normas sectoriales relacionadas con el lobo, como son las que regulan la actividad cinegética, pero su análisis excede la intención de este trabajo.

El art. 148 del texto constitucional español establece un elenco de materias que podrán ser asumidas por las CCAA. Entre ellas, podrán tener competencia, como señala el apartado $9^{\circ}$, en la gestión de protección del medio ambiente. Recordemos que el art. 149 del mismo texto otorgaba al Estado la competencia exclusiva sobre la legislación básica de protección del medio ambiente. Por tanto, las CCAA tienen encomendada la gestión y la ejecución de la materia en sus correspondientes territorios, promulgando leyes y reglamentos en este sentido.

Los Estatutos de autonomía de las distintas CCAA recogen también la competencia exclusiva para dictar normas adicionales de protección del medio ambiente. Así, por ejemplo, en el Estatuto de Autonomía de Cataluña, en su art. 144, se establece que corresponde a la Generalitat la competencia compartida en materia de medio ambiente. En Andalucía, por poner otro ejemplo, el art. 57 del Estatuto de Autonomía para Andalucía, le atribuye la competencia exclusiva en materia de fauna y flora silvestres, dentro del marco 
normativo estatal.

Realizar una síntesis de toda la normativa referente a la conservación de la biodiversidad existente en las CCAA tampoco es el objeto del trabajo. No obstante, si puede ser útil una visualización general del tema, para establecer algunas diferencias entre ellas.

Las CCAA que cuentan con la mayor parte de población de lobos de la Península Ibérica, tienen catalogada la especie como cinegética, ya sean a través de sus leyes de caza, los reglamentos de desarrollo o los llamados Planes de gestión del lobo. Es el caso de Cantabria, Castilla y León o Galicia. No deja de sorprender que en La Rioja el lobo sea también especie cinegética ${ }^{121}$ y que en el último censo oficial solo se contabilice una manada compartida con otras CCAA colindantes. El Decreto 59/1998, de 9 de octubre, por el que se crea y regula el Catálogo Regional de Especies Amenazadas de la Flora y Fauna Silvestre de La Rioja tampoco incluye al lobo en ninguna categoría. Evidentemente, no se ha planteado ningún plan de recuperación de la especie.

Amparados en la permisividad del marco legislativo sobre la protección del lobo al norte del Duero, se establecen planes de gestión de la especie: en Galicia ${ }^{122}$, en Cantabria ${ }^{123}$, en Castilla y León ${ }^{124}$; todos ellos con la finalidad teórica del equilibrio ecológico, y con la finalidad práctica de ofrecer una pieza codiciada por muchos cazadores.

En el cuadrante noroeste, el caso del Principado de Asturias podríamos calificarlo como sui generis. Por un lado, su normativa autonómica no declara al lobo como especie cinegética, pero sí establece un plan de gestión ${ }^{125}$, autorizando batidas en unas zonas de su territorio y prohibiéndolas en otras ${ }^{126}$.

En el País Vasco, el lobo se incluye en la categoría de especie de "Interés Especial"127, dentro del Catálogo Vasco de Especies Amenazadas de Fauna y Flora Silvestre y Marina ${ }^{128}$, categoría con un nivel de protección por debajo del que recibe en el CEA cualquier especie catalogada como "vulnerable". En Navarra, no figura bajo ninguna categoría, ni tan siquiera como especie extinguida ${ }^{129}$; al igual que en Aragón ${ }^{130}$. En Murcia, se considera especie extinguida ${ }^{131}$, y en la Comunidad Valenciana no aparece en su Catálogo de Especies de Fauna Amenazadas ${ }^{132}$.

En la Comunidad de Madrid, aunque en el último censo oficial se contabilizara una manada, en el Decreto 18/1992, de 26 de marzo, por el que se aprueba el Catálogo Regional de especies amenazadas de fauna y flora silvestres y se crea la categoría de árboles singulares, tampoco aparece el lobo. En Extremadura, el lobo no cuenta con ningún plan de recuperación, si bien está catalogado como especie en peligro de extinción ${ }^{133}$. En Castilla-La Mancha, la especie está catalogada como en peligro de extinción ${ }^{134}$.

Andalucía cuenta con una población exigua de lobos en la zona centro-oriental de Sierra Morena, aislada de las otras poblaciones ibéricas más al norte, y en serio peligro de extinción. Esta afirmación, tal vez sea más un deseo que una realidad. De hecho, desde 2013 no se tienen indicios ciertos de presencia de la especie en dicha comunidad autónoma ${ }^{135}$. Aún así, la Junta de Andalucía tiene en vigor un proyecto para

\footnotetext{
${ }^{121}$ Decreto 17/2004, de 27 de febrero, por el que se aprueba el Reglamento de Caza de La Rioja.

122 Decreto 297/2008, de 30 de diciembre, por el que se aprueba el Plan de gestión del lobo en Galicia.

${ }^{123}$ Orden MED/5/2019, de 28 de marzo, por la que se aprueba el Plan de Gestión del Lobo en Cantabria.

${ }^{124}$ Resolución de 9 de octubre de 2019, de la Dirección General del Patrimonio Natural y Política Forestal, por la que se aprueba el Plan de aprovechamientos comarcales de lobo en los terrenos cinegéticos situados al norte del Río Duero en Castilla y León para las temporadas 2019/2020, 2020/2021 y 2021/2022.

${ }^{125}$ Decreto 23/2015, de 25 de marzo, por el que se aprueba el II Plan de Gestión del Lobo en el Principado de Asturias.

${ }^{126}$ Esta regulación sui generis no frena la existencia de irregularidades en la gestión del lobo, como demuestra el hecho de que diversas plataformas conservacionistas (Observatorio Justicia y Defensa Animal, ASCEL,...) interpusieran una denuncia por este motivo ante la Comisión Europea en 2013.

Vid.: https://justiciaydefensaanimal.es/pol\%C3\%ADtica/

${ }^{127}$ Orden de 2 de marzo de 2020, del Consejero de Medio Ambiente, Planificación Territorial y Vivienda, por la que se modifica el Catálogo Vasco de Especies Amenazadas de Fauna y Flora Silvestre y Marina, y se incluye al lobo (Canis lupus) en la categoría de especie de "Interés Especial".

${ }^{128}$ Decreto 167/1996, de 9 de julio, por el que se regula el Catálogo Vasco de Especies Amenazadas de la Fauna y Flora, Silvestre y Marina.

${ }^{129}$ Decreto Foral 254/2019, de 16 de octubre, por el que se establece el Listado navarro de especies silvestres en régimen de protección especial, se establece un nuevo Catálogo de especies de flora amenazadas de Navarra y se actualiza el Catálogo de especies de fauna amenazadas de Navarra.

${ }^{130}$ Decreto 181/2005, de 6 de septiembre, del Gobierno de Aragón, por el que se modifica parcialmente el Decreto 49/1995, de 28 de marzo, de la Diputación General de Aragón, por el que se regula el Catálogo de Especies Amenazadas de Aragón.

${ }^{131}$ Ley $7 / 1995$, de 21 de abril, de la fauna silvestre, caza y pesca fluvial.

${ }^{132}$ Decreto 32/2004, de 27 de febrero, del Consell de la Generalitat, por el que se crea y regula el Catálogo Valenciano de Especies de Fauna Amenazadas, y se establecen categorías y normas para su protección.

${ }^{133}$ Decreto 78/2018, de 5 de junio, por el que se modifica el Decreto 37/2001, de 6 de marzo, por el que se regula el Catálogo Regional de Especies Amenazadas de Extremadura.

${ }_{134}$ Decreto 33/1998, de 5 de mayo, por el que crea el Catálogo Regional de Especies Amenazadas de Castilla-La Mancha.

135 "Cambiando actitudes para lograr la coexistencia con el lobo ibérico", Revista Quercus 413 (julio 2020), 28-35. 
mejorar la coexistencia del lobo con las poblaciones rurales y con los sectores implicados ${ }^{136}$, que se enmarca dentro del programa europeo LIFE para la sensibilización sobre los grandes carnívoros. Su finalidad última es evitar la extinción del lobo en Andalucía.

El Listado Andaluz de Especies Silvestres en Régimen de Protección Especial, que incluye el Catálogo Andaluz de Especies Amenazadas, es un instrumento creado a partir de la Ley 8/2003 de la Flora y Fauna Silvestre de Andalucía. Resulta difícil entender que no aparezca el lobo entre las especies del listado como especie amenazada y con un plan de recuperación y conservación; es más, no aparece de ninguna forma. Evidentemente, cuenta con la protección que genera la normativa estatal, pero la situación demuestra una falta rigor administrativo y jurídico por parte de la Administración andaluza.

Castilla y León es la comunidad autónoma que alberga en su territorio la mitad de la población de lobos que actualmente sobreviven en la Península Ibérica. Y es en su territorio donde se ubica la frontera física que decide, según la normativa vigente, si los lobos pueden ser abatidos o no, por motivos cinegéticos. Evidentemente, es la comunidad donde la conflictividad entre los agentes implicados en la conservación del lobo y los interesados en que se les cace, llega a cotas más altas. Analizar este conflicto excede nuestra intención, si bien sería revelador para vislumbrar los intereses existentes en mantener la especie como objeto de caza y desproteger la conservación de la misma. Un botón de muestra puede verse en la propia exposición de motivos de la ley de Caza ${ }^{137}$, que afirma: "En Castilla y León, más del $88 \%$ de su superficie son terrenos cinegéticos y la mayor parte de los mismos, en torno a $78.000 \mathrm{Km}^{2}$, están constituidos bajo la figura de cotos privados de caza."

Según la Ley 9/2019, de 28 de marzo, de modificación de la Ley 4/1996, de 12 de julio, de Caza en la Comunidad Autónoma de Castilla y León, Canis lupus es especie cinegética de caza mayor. A modo de resumen, el lobo es especie cinegética al norte del río Duero y protegida al sur de mismo río.

La Dra. Eva Blasco Hedo, responsable de la Unidad de Investigación y Formación del CIEDACIEMAT, expone de manera diáfana la situación del lobo y su caza en esta comunidad, en su comentario al Auto de la Sala de lo Contencioso Administrativo del TSJ de Castilla y León, de 21 de febrero de 2019, que supuso la suspensión provisional de la actividad cinegética por estimación de una medida cautelar ${ }^{138}$. Así, en la comunidad autónoma de Castilla y León se ha pasado de un marco jurídico en el que una ley de caza establecía que un reglamento debía enumerar las especies consideradas cinegéticas, y que unas órdenes anuales de caza debían establecer, de entre estas, las especies que podían cazarse, a una nueva ley de caza que sí establece cuales son las especies cinegéticas y, además, añade que todas las especies cinegéticas son cazables. No se trata de un cambio sin importancia, ya que, en opinión de la Dra. Eva Blasco: “... ha servido para de alguna manera sortear el cumplimiento del tan reiterado auto judicial en lo que a la suspensión cautelar de la actividad cinegética se refiere"139. Y añade: "Tampoco se puede perder de vista que prácticamente la única posibilidad de recurrir la Ley es a través del recurso de inconstitucionalidad ante el Tribunal Constitucional, de ahí que la opción entre aprobar un Decreto o una Ley no es baladí sino que conlleva repercusiones en orden a la naturaleza de los recursos que caben contra estas normas y las personas legitimadas para interponerlos." 140

El Dr. Carlos Javier Durà Alemañ, investigador del CIEDA, comentando la Sentencia 148/2020 del Pleno del Tribunal Constitucional, donde el Defensor del Pueblo plantea recurso de inconstitucionalidad contra varios apartados del artículo único de la Ley 9/2019, señala como el Tribunal declara la constitucionalidad de la ley autonómica, entre otros motivos, "al no hacer mención en el texto de la demanda de cuáles deben ser esos informes o estudios técnicos omitidos, al no concretar la fuente normativa que los exige" 141 . Y este es uno de los aspectos más trascendentales de todo el entramado que acompaña a la caza del lobo: los estudios e informes técnicos que relacionen la caza y la conservación de la especie. Como acertadamente apunta la Dra. Eva Blasco Hedo: "El problema es determinar cuál debe ser su alcance y su contenido; si son preciosos, actualizados y objetivos". ${ }^{142}$

El conflicto entre la Administración autonómica y los agentes conservacionistas viene de lejos, y tiene

\footnotetext{
${ }^{136}$ LIFE SOUTHERN WOLVES. The wolf of Andalusia: Changing attitudes. Vid.: http://www.juntadeandalucia.es/medioambiente/portal_web/web/temas_ambientales/programas_europeos_y_relac_internac/program as_europeos/life/proyectos_ejecucion/SOUTHERN\%20WOLVES/LIFE\%20Southern\%20Wolwes/Ficha\%20 proyecto\%20web.pdf

${ }^{137}$ Ley 9/2019, de 28 de marzo, de modificación de la Ley 4/1996, de 12 de julio, de Caza en la Comunidad Autónoma de Castilla y León.

${ }^{138}$ Blasco Hedo, E., Suspensión provisional de la actividad cinegética por la estimación judicial de una medida cautelar versus modificación de la Ley de Caza de Castilla y León que autoriza su ejercicio, Actualidad Jurídica Ambiental, n. 89, 2019. Vid.: https://www.actualidadjuridicaambiental.com/wp-content/uploads/2019/04/2019_04_29_Blasco_Suspension-cautelar-caza-CyL.pdf 139 Blasco Hedo, E., op. cit., 14.

${ }^{140}$ Blasco Hedo, E., op. cit., 14.

${ }^{141}$ DuràAlemañ, C.J., Comentario a la Sentencia 148/2020, de 22 de octubre de 2020, del Pleno del Tribunal Constitucional en https://www.actualidadjuridicaambiental.com/jurisprudencia-al-dia-tribunal-constitucional-castilla-y-leon-caza/

${ }^{142}$ Blasco Hedo, E., op. cit., 14.
} 
su reflejo en múltiples acciones en el ámbito jurisdiccional. Así, por ejemplo, la asociación ASCEL solicitó la nulidad de pleno derecho de una Resolución, de 29 de julio de 2016, de la Dirección General del Medio Natural (Consejería de Fomento y Medio Ambiente de la Junta de Castilla y León), que aprobaba el Plan de aprovechamientos comarcales de lobo en los terrenos cinegéticos situados al norte del Río Duero para las temporadas 2016/2017, 2017/2018 y 2018/2019. La demanda fue estimada por la Sala de lo Contencioso del Tribunal Superior de Justicia de Castilla-León, con fecha 12 de diciembre de 2019 ${ }^{143}$. La Dra. Eva Blasco, comentando dicha sentencia, destaca el hecho de que se considera a la Administración Autonómica responsable del daño a la especie, estableciéndose una indemnización, que dicha Administración, debe destinar a actuaciones a favor de la recuperación y conservación del lobo ${ }^{144}$. Entre otras sentencias a favor de las pretensiones de entidades conservacionistas podrían citarse las de 25 de enero y de 12 de febrero, ambas de 2018, del TSJ de Castilla y León, basadas en la omisión de dictamen preceptivo o por establecer la gestión de la especie con instrumentos de rango insuficiente ${ }^{145}$.

Lidia García Martín ha realizado un estudio minucioso del estatus jurídico del lobo, sobre todo en la comunidad castellano-leonesa, indagando en la problemática jurídica y social que plantea esta especie. Es de gran interés su estudio de la percepción del sector cinegético sobre la gestión de la especie, pero también su análisis jurisprudencial de la responsabilidad patrimonial por los daños que causa el lobo ${ }^{146}$. Comparto profundamente una de sus reflexiones:

Se ha culpado a la especie del lobo ibérico por el daño que ha provocado y que sigue provocando en la actualidad a diferentes sectores socioeconómicos de nuestro país, si bien el profundo odio que ha despertado en esos sectores ha venido motivado, principalmente, por la indiferencia y el abandono al que se han visto relegados. La ausencia de propuestas y medidas que permitan anticiparse a los ataques al ganado, las barreras para el ejercicio de la acción de responsabilidad patrimonial pública por los daños que causa al sur del río Duero, el tortuoso e intrincado camino a seguir para la concesión de indemnizaciones por los ataques del cánido, así como el tan frecuente retraso en la concesión y pago de las citadas ayudas, han sido desencadenantes del conflicto al que nos enfrentamos hoy día al intentar procurar la compatibilidad entre el lobo ibérico y, en particular, la actividad ganadera. ${ }^{147}$

Lidia García Martín refleja, en sus trabajos sobre el lobo, la mayoría de las acciones que podrían acometerse para prevenir los daños a la ganadería y permitir la coexistencia con esta especie; acciones suscritas por la mayoría de entidades conservacionistas y también expuestas en este trabajo. No obstante, discrepo en la reflexión de que los intereses del sector cinegético y la conservación del lobo, en el fondo, puedan ser compatibles. La experiencia demuestra que para avanzar en temas que generan acalorados debates, en la mayoría de los casos, es necesario el consenso entre los distintos agentes implicados. Tal vez sea este el caso, pero ello no esconde una realidad, con un marcado matiz ético, cada vez más emergente: la caza no es una necesidad para el equilibrio de las especies y la muerte de especies vulnerables no puede justificarse bajo el paraguas de la obtención de beneficios económicos. Recordemos que a lo largo de nuestra historia reciente se han producido reconversiones económicas de sectores productivos significativos. Así, en esta línea, abogaría más por la prohibición de la caza de los escasos grandes carnívoros que aún sobreviven en Europa, aunque fuera de forma escalonada, implementando ayudas a la reconversión del sector cinegético.

Volviendo a la conflictividad de intereses ante los tribunales, no es un hecho exclusivo de la comunidad castellano-leonesa. Así, por poner algunos ejemplos, en la Comunidad de Madrid se ha acabado en el Tribunal Supremo, resolviendo recurso de casación, por los daños y perjuicios provocados por el lobo en una explotación ganadera ${ }^{148}$; o en la Comunidad cántabra, con otra sentencia de Tribunal Supremo sobre el reconocimiento de la legitimación activa de una asociación ecologista para cuestionar el control población del lobo en esa comunidad ${ }^{149}$.

\footnotetext{
${ }^{143}$ Sentencia No 1458/2019, del Tribunal Superior de Justicia de Castilla-León, de 12 de diciembre de 2019.

${ }^{144}$ Blasco Hedo, E., en https://www.actualidadjuridicaambiental.com/jurisprudencia-al-dia-castilla-y-leon-planes-lobo-caza/

145 Comentarios de E. Blasco Hedo a la STSJ CL, de 25 de enero de 2018, y STSJ CL de 12 de febrero de 2018. Vid.: https://www.actualidadjuridicaambiental.com/jurisprudencia-al-dia-castilla-y-leon-plan-de-conservacion-y-gestion-del-lobo/ y también, https://www.actualidadjuridicaambiental.com/jurisprudencia-al-dia-castilla-y-leon-plan-de-aprovechamientos-comarcalesdel-lobo/

${ }^{146}$ García Martín, L., El estatus jurídico del lobo ibérico en el punto de mira: un cambio de paradigma en Castilla y León, en Revista Jurídica de Castilla y León, núm. 50, enero 2020, https://www.jcyl.es/web/jcyl/AdministracionPublica/es/Plantilla100Detalle/1215245063566/Publicacion/1284922038764/Redaccion ${ }_{147}$ García Martín, L., op. cit., p. 132.

148 Mora Ruiz, M., Comentario a la Sentencia del Tribunal Supremo de 11 de febrero de 2020. Vid.: https://www.actualidadjuridicaambiental.com/jurisprudencia-al-dia-tribunal-supremo-proteccion-de-especies-responsabilidadpatrimonial/

${ }^{149}$ Casado Casado, L., Sentencia del Tribunal Supremo de 23 de noviembre de 2020, en Actualidad Jurídica Ambiental, enero 2021. 174 Derecho Animal. Forum of Animal Law Studies, vol. 12/2
} 
Cataluña, tal vez, represente el polo opuesta a la comunidad castellano-leonesa. El lobo se extinguió en su territorio ya en la primera mitad del siglo XX, motivo por el cual la normativa actual no lo contemplaba. En el Decreto Legislativo 2/2008, de 15 de abril, por el cual se aprueba el Texto refundido de la Ley de protección de los animales, en su Anexo sobre Especies protegidas de la fauna salvaje autóctona, ni tan siquiera se le cita. Tampoco es considerada especie cinegética. En los últimos años, la aparición de algunos lobos en los Pirineos ha ido acompañada de un cierto debate entre ganaderos y conservacionistas. No obstante, los poderes públicos han optado por la vía de la defensa de la biodiversidad y el cumplimiento del marco normativo comunitario y estatal. En este sentido, a diferencia de la posición de otras CCAA, la Generalitat ha presentado, recientemente, un proyecto de nuevo Catálogo de fauna salvaje autóctona amenazada ${ }^{150}$, en la que incluye al lobo en la categoría de especie "Extinta como reproductor en Cataluña". En el proyecto presentado, se habilita un procedimiento administrativo para la reintroducción de especies extintas incluidas en el Catálogo, así como reintroducciones locales y repoblaciones. Recordemos que tanto la Ley 42/2007 como el RD 139/2011 también establecen esta posibilidad de reintroducción de especies extintas. Si este proyecto se consolida, podríamos hablar de la primera comunidad autónoma donde se implementan planes de recuperación de especies autóctonas extintas, en consonancia con el contenido normativo de la legislación europea y la legislación básica estatal, lo que supondría cumplir con las obligaciones que tienen encomendados los poderes públicos en este tema.

En esta línea, el Parlamento de Cataluña también ha dado un paso más, y recientemente ha aprobado la Ley $7 / 2020$, de 2 de julio, de la Agencia de la Naturaleza de Cataluña, con el objetivo, entre otros, de preservar el patrimonio natural i la biodiversidad ${ }^{151}$.

\section{Las divergencias normativas entre CCAA sobre la protección y la caza del lobo}

La aplicación de la Ley 42/2007, así como la normativa comunitaria y los convenios internacionales en materia de conservación de la biodiversidad, hace necesaria una información veraz, tanto científica como técnica. La Administración general del Estado ha configurado toda la estructura orgánica y funcional expuesta en el apartado anterior para lograr que la aplicación de todo ese marco jurídico sea una realidad. Así, se elaboran directrices técnicas desde los grupos de trabajo dependientes del Comité de Flora y Fauna Silvestres para orientar y coordinar las actuaciones de los órganos competentes en la materia de las CCAA. Estas directrices son aprobadas por la Comisión Estatal para el Patrimonio Natural y la Biodiversidad y, en ocasiones, también por la Conferencia Sectorial de Medio Ambiente. En este procedimiento también participa el Consejo Estatal para el Patrimonio Natural y la Biodiversidad, como órgano de participación pública. Con todo ello, debería lograrse una ejecución eficaz de la normativa, al igual que una óptima coordinación a nivel estatal.

Pero la realidad es otra. La organización descrita establece vías de coordinación entre las distintas AAPP, con la participación de los agentes sociales interesados en el tema. Sin embargo, las CCAA actúan más a nivel individual que colectivo en un tema en el cual es imprescindible la participación de todos: el lobo, como cualquier otra especie silvestre, no entiende de divisiones administrativas y políticas, y su conservación tampoco. Detrás de esta actitud se ocultan distintos intereses políticos existentes en la CCAA, así como las presiones de los sectores económicos interesados en que la situación actual se perpetúe.

El art. 7.1 de la Ley 42/2007 dispone que las administraciones públicas cooperarán y colaborarán en materia de conservación del patrimonio natural y la biodiversidad, y se suministrarán mutuamente información para garantizar el cumplimiento de sus objetivos. Para conseguir esta finalidad se crea la ya mencionada Comisión Estatal para el Patrimonio Natural y la Biodiversidad, mediante el R.D. 1424/2008. Pero, ¿ha sido plausible esta cooperación y colaboración en materia de conservación del lobo entre administraciones públicas? La situación del lobo en los últimos decenios demuestra lo contrario. En algunas CCAA continúa subsistiendo, sin que la supuesta expansión de la especie, argumentada por algunos, sea una evidencia. Es más, desde la perspectiva de las voces a favor de una conservación más estricta de la especie, se aboga por calificar como "especie vulnerable" -cuanto menos no cinegética- las poblaciones al norte del río Duero, y el resto como especie "en peligro de extinción". Los lobos, en los territorios donde las poblaciones eran ínfimas, continúan en ese estado, si no se han extinguido.

\footnotetext{
Vid.: https://www.actualidadjuridicaambiental.com/wp-content/uploads/2021/01/2021_01-Recopilatorio-108-AJA-Enero.pdf

${ }^{150}$ Edicto de 23 de julio de 2020, por el cual se somete a información pública el Proyecto de decreto del Catálogo de la fauna salvaje autóctona amenazada y de otros aspectos relativos a la fauna salvaje autóctona protegida.

${ }^{151}$ Carlos Javier Durá Alemañ comenta de manera breve y acertada esta norma en la revista Actualidad Jurídica Ambiental, justificando la necesidad de crear dicha Agencia. Vid.: https://www.actualidadjuridicaambiental.com/legislacion-al-dia-cataluna-agencia-de-lanaturaleza-de-cataluna/
} 
Las CCAA de Andalucía, Castilla-La Mancha y Extremadura, que en la primera versión del LESPRE ya incluían al lobo como especie protegida, deberían haber establecido planes de recuperación de la especie, y no existen como tales. Además, mientras Castilla-La Mancha y Extremadura clasifican al lobo como especie en peligro de extinción en sus respectivos catálogos regionales de especies amenazadas, Andalucía no ha incorporado aún la especie a su catálogo. Para mayor desatino, resulta que la población de lobos en Andalucía, aunque reducidísima, aún persiste, mientras que en las otras dos comunidades señaladas su número es casi nulo: en el último censo oficial, Castilla-La Mancha solo tenía una manada estable, y Extremadura, ninguna. Si se observa algún lobo en Extremadura, lo más probable es que sea un ejemplar "visitante" procedente de tierras portuguesas.

Las CCAA del noreste peninsular, donde la población de lobos es más numerosa y estable, son las que establecen planes de gestión del lobo. Pero esos planes se dirigen hacia la actividad cinegética y no, por ejemplo, hacia un turismo lobero bien entendido. Obviamente, tampoco promueven la recuperación del lobo.

Una cuestión que probablemente mejoraría la situación del lobo es la aceptación del hecho que su protección y gestión debe tener un carácter interterritorial. Nos referimos a la necesidad de unas mismas políticas en relación con la conservación de la especie, ya que los hábitats naturales y las especies silvestres no se acotan con divisiones territoriales derivadas de la organización humana ${ }^{152}$. Las normas comunitarias también recogen este principio de actuación en materia de medio ambiente y biodiversidad ${ }^{153}$.

Todas las CCAA colindantes con las del cuadrante noreste de la Península, último reducto del lobo ibérico, en cierta forma, ocultan al lobo. En algunas es especie cinegética, como en La Rioja, o se le da una protección por debajo de los estándares establecidos en la CEA, como en el País Vasco. Y eso teniendo en cuenta que en ambas comunidades no existe ninguna manada estable, según el último censo oficial. Con ello, queda demostrada la actitud de los poderes públicos en general, con un incumplimiento sistemático de sus obligaciones dentro del marco jurídico actual.

Algo similar ocurre en comunidades donde el lobo ha sido extinguido hace años: donde aparece, aunque sea esporádicamente como transeúnte, se convierte automáticamente en "especie non grata". Como ya dijimos, el caso de Cataluña tal vez se convierta en la primera excepción, si prosperan las iniciativas actuales. Y, recordemos, que la misma Directiva Hábitats permite la reintroducción de especies de fauna indígena.

\section{Derecho y sociedad: un futuro para el lobo}

No podemos hablar de solución sin que dos elementos esenciales entren en juego: derecho y sociedad. El segundo de ellos ya hace tiempo que está trabajando para lograr una protección adecuada para una de las especies más emblemáticas de la fauna ibérica. El primero, no ha logrado la necesaria protección del lobo, y es urgente que empiece a generar la sinergia de todos los agentes jurídicos para que se produzcan avances. El poder legislativo y el ejecutivo tienen una gran responsabilidad en el tema.

Como señala la Dra. Giménez-Candela, “....al Estado le corresponde la responsabilidad sobre los animales en una doble vertiente: la de defensa y punición frente al maltrato (Derecho Penal) y la de velar por el cumplimiento de las normas relativas al bienestar de los animales... y fauna silvestre, en virtud, en nuestro caso, de nuestra condición de Estado miembro de la UE"154.

\section{Exposición crítica del actual estatus legal del lobo en el Derecho español}

La Ley 42/2007, del Patrimonio Natural y de la Biodiversidad, recoge en su art. 1 el objeto de la ley: establecer "el régimen jurídico básico de la conservación, uso sostenible, mejora y restauración del patrimonio natural y de la biodiversidad, como parte del deber de conservar y del derecho a disfrutar de un medio ambiente adecuado para el desarrollo de las personas, establecido en el artículo 45.2 de la Constitución".

El objetivo es muy loable; habla de la conservación, uso sostenible, mejora y restauración de la biodiversidad. No obstante, la realidad demuestra que buena parte de los poderes públicos solo tienen en cuenta la gestión del lobo y, como mucho, su uso sostenible. La mejora y restauración de la especie, como parte de la biodiversidad y con una clara función en los ecosistemas que habita, son aspectos completamente relegados. Quizá se hable de su conservación, pero sin atender a principios establecidos en la propia ley. Y

\footnotetext{
${ }^{152}$ Este argumento se recoge, paradójicamente, en el Anexo I de la Resolución de 6 de marzo de 2017, de la Dirección General de Calidad y Evaluación Ambiental y Medio Natural, por la que se publica el Acuerdo del Consejo de Ministros de 24 de febrero de 2017, por el que se aprueban los criterios orientadores para la inclusión de taxones y poblaciones en el Catálogo Español de Especies Amenazadas.

${ }^{153}$ El carácter transfronterizo del Patrimonio natural de la Comunidad se recoge, por ejemplo, en los considerandos de la Directiva Hábitats.

${ }^{154}$ Giménez-Candela, T., op. cit., 30.

176 Derecho Animal. Forum of Animal Law Studies, vol. 12/2
} 
me refiero, por ejemplo, a los deberes de los poderes públicos: "Integrarán en las políticas sectoriales los objetivos y las previsiones necesarios..., la prevención de la fragmentación de los hábitats y el mantenimiento $\mathrm{y}$, en su caso, la restauración de la integridad de los ecosistemas" ${ }^{155}$.Recordemos que el criterio seguido para poder matar al lobo es si está al norte o al sur del río Duero. La desatención por parte del legislador del hecho de que un río no marca el hábitat de esta especie, ceguera más voluntaria que involuntaria, conduce a una deficiente conservación del lobo.

La propia Ley 42/2007, en su art. 3, define lo que entiende por corredor ecológico: “...territorio, de extensión y configuración variables, que, debido a su disposición y a su estado de conservación, conecta funcionalmente espacios naturales de singular relevancia para la flora o la fauna silvestres, separados entre sí, permitiendo, entre otros procesos ecológicos, el intercambio genético entre poblaciones de especies silvestres o la migración de especímenes de esas especies". Parece ser que al legislador se le olvidó que para la conservación del lobo se necesitan corredores ecológicos, no fronteras, además de acciones de gestión activa y no de gestión cinegética.

En el art. 2 de la misma ley, donde se exponen sus principios inspiradores, el apartado g) dice: "La precaución en las intervenciones que puedan afectar a espacios naturales o especies silvestres". Principio de precaución que también recoge el TFUE, en su art. 191. La actividad cinegética debería autorizarse en casos excepcionales, atendiendo a este principio. El citado artículo de la norma europea también se refiere a la necesidad de elaborar una política de medio ambiente con datos científicos y técnicos. La caza del lobo, sin unos conocimientos científicos ampliamente aceptados sobre, por ejemplo, su volumen poblacional, sería una actuación sin atender esta exigencia comunitaria, como tampoco al principio de precaución.

No obstante, la Ley 42/2007, en el art. 2.b), da cabida a una interpretación amplia del deber de conservar, mejorar y restaurar la biodiversidad (reconocido en el art. 45 de la CE): Las medidas que se adopten para ese fin tendrán en cuenta las exigencias económicas, sociales y culturales, así como las particularidades regionales y locales." Introduce factores económicos, sociales, culturales y territoriales sobre un tema que no admite per se estos condicionantes, y que es el de la conservación de especies silvestres cuando éstas deben tener una protección especial. Es más, si aceptamos que la caza del lobo no es una actividad cultural a proteger, que la sociedad no exige matar lobos (salvo algunos cazadores y ganaderos), y que el pretexto económico que puede argumentarse son las pérdidas de ganado causadas por el lobo, y esto puede remediarse con ayudas al sector, poco queda en a favor de la caza del lobo.

La Ley 42/2007 establece una estructura organizativa que promete una óptima conservación de la biodiversidad, pero en el caso del lobo no se plasma en una realidad jurídica. La diversidad de criterios entre las CCAA en cuanto a la protección, recuperación y gestión del lobo son un hándicap para avanzar en el camino correcto para la conservación de la especie, desde el punto de vista del marco normativo europeo y estatal. Las decisiones dependen de la línea seguida en política medio ambiental por el poder ejecutivo, tanto estatal y como autonómico, en lugar de ceñirse al marco normativo vigente. Por añadidura, los diversos instrumentos jurídicos utilizados (leyes, reglamentos, etc.) no cumplen siempre los principios que se desprenden del texto constitucional español o de las normas comunitarias en materia de protección de las especies. Esto demuestra, en muchos casos, la falta de sensibilidad del legislador español ante los principios que sustentan los convenios internacionales y la legislación europea en relación a la protección del lobo. ¿Existen mecanismos suficientes de inspección responsables? ¿Se imponen penas lo suficientemente disuasorias para que los infractores abandonen esas prácticas? La respuesta, seguramente, es no.

La reserva que se incluye en la ratificación por España del Convenio de Berna sobre el lobo supone ya un primer agravio significativo para esta especie. Agravio que continua en la Directiva Hábitats y la distinción entre lobos para la caza y lobos protegidos según su ubicación (norte o sur del Duero).

Otro principio incumplido es el de la prohibición de arbitrariedad de los poderes públicos, recogido en el art. 9.3 del texto constitucional. Un ejemplo puede verse en el contexto que envuelve al lobo en la comunidad autónoma de Castilla y León, donde la Administración autonómica parece decantarse por interpretar la legislación según los intereses de un sector determinado de su ciudadanía. Esto provoca un descrédito evidente de los poderes públicos, de sus instituciones, que repercute negativamente en una posible solución a los problemas planteados.

Aspectos que deberían mejorar son la aplicación de los conocimientos científicos y técnicos sobre el lobo en la elaboración de normativa y planes de gestión; así como también, las acciones informativas sobre la ecología del lobo, función realizada en mayor medida por asociaciones conservacionistas que por las AAPP. Eso no quiere decir que no haya iniciativas muy loables en este sentido desde las AAPP, como por ejemplo, el Congreso Internacional sobre la gestión y conservación del lobo en Norteamérica y Europa celebrado en Zamora en abril de 2017. 
Estudios serios sobre el lobo, como el elaborado por el Grupo de Trabajo del Lobo, que condujo a la aprobación de una Estrategia para la conservación y gestión del lobo, ya citado anteriormente, no se ven reflejados en gran medida en las actuaciones posteriores de las AAPP, lo cual genera un descontento justificado entre los sectores conservacionistas y la propia comunidad científica. Es otro de los problemas que necesita de una solución inmediata para que exista una correcta elaboración de la normativa aplicable al lobo, así como para la configuración de sus actuales planes de gestión.

El lobo europeo, en relación con su estado de conservación, está clasificado en la categoría de preocupación menor ${ }^{156}$, según la Lista Roja de la UICN. En España, un documento del MITECO sobre el estado de conservación del lobo ${ }^{157}$ demuestra la insuficiente consistencia de la información que se tiene sobre el mismo y como debería clasificarse. En la justificación de los criterios para establecerlo en una de las categorías, en unas seis líneas, se dice que: “...está próximo a la categoría de Vulnerable o incluso podría ser considerado como tal. No obstante, la población ha aumentado en los últimos 35 años; además, la población española es contigua a la portuguesa,.... Por tales motivos se ha decidido considerarle como Casi Amenazado $(\mathrm{NT}=$ Near Threatened)". Agustín García Ureta, analizando normativa y jurisprudencia de la UE, señala que el examen del estado de conservación del lobo da como resultado un estado desfavorable ${ }^{158}$.

Realicemos ahora un pequeño ejercicio numérico. El último censo del lobo ibérico (2012-2014) ${ }^{159}$, documento del Ministerio de Agricultura, Alimentación y Medio Ambiente, da un total para toda España de 297 manadas, entre las manadas exclusivas de cada CCAA y las manadas compartidas. Se contabilizan 19 manadas compartidas, que se reparten prácticamente en su totalidad entre Galicia, Asturias, Cantabria y Castilla y León, y representan un 6,4\% del total. Si descartamos estas manadas compartidas y analizamos las demás en relación con su posición respecto al río Duero, el resultado sería que al norte del río se concentra casi el $70 \%$ de las manadas (194), y al sur el 30\% restante (84). Este simple ejercicio muestra como la población de lobos que protege la legislación española solo es efectiva, si se aplicara de forma correcta, para el $30 \%$ de su población. El resto son considerados ejemplares cinegéticos, sin protección alguna, aunque se establezcan cupos -por lo general anuales- para su caza. También se hace evidente que el área de distribución del lobo no se ha expandido de manera desmesurada, por mucho que algunos se empeñen en decir lo contrario. Es más, el censo oficial solo contabiliza una manada exclusiva de Castilla-La Mancha y otra en Madrid, y una compartida respectivamente en País Vasco, La Rioja y Castilla-La Mancha, si bien es cierto que hay constancia de un cierto crecimiento poblacional reciente en alguna comunidad, como la de Madrid ${ }^{160}$.

Ante este panorama, ¿cómo puede hablarse de una protección de la especie eficaz en el Estado español, o de que su estado de conservación es tan favorable que puede permitirse su explotación como especie cinegética? En todas las CCAA donde está presente, o es especie cinegética o tiene un plan de gestión (caso de Asturias). Es especie protegida en Andalucía, en Castilla-La Mancha o en Extremadura, cuando en estas comunidades está a un paso de la extinción, o su presencia es testimonial o es especie extinguida.

Castilla y León es la comunidad más problemática, y quizá sea donde se resuelva el futuro de la conservación del lobo ibérico, para bien o para mal. Esperemos que los poderes públicos de la Comunidad entiendan la necesidad de proteger con mayor entrega al lobo, para cumplir con los principios generales que informan todos los tratados internacionales y las legislaciones comunitaria y estatal.

Se podrá hablar de una buena salud del lobo cuando haya una recuperación suficiente en parte de sus hábitats anteriormente ocupados; en la actualidad, esta situación es solo un deseo. La población de lobos no se ha incrementado numéricamente como debería, presentando resultados similares en los últimos decenios, ni tampoco ha recuperado territorios ocupados durante buena parte del siglo pasado.

\section{Coordinación de competencias legislativas como una posible solución para una protección adecuada de la especie.}

Uno de los principios rectores de la política social y económica, que aparece en el Capítulo III del Título I de la CE, es el que establece el art. 45.2: "Los poderes públicos velarán por la utilización racional de todos los recursos naturales, con el fin de proteger y mejorar la calidad de la vida y defender y restaurar el medio ambiente, apoyándose en la indispensable solidaridad colectiva."

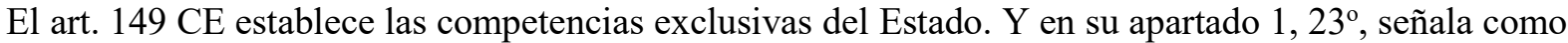

\footnotetext{
${ }^{156}$ Clasificado como LC (LeastConcern). Vid.: https://www.iucnredlist.org/es/search?query=Canis\%20lupus\&searchType=species

157 Vid. web MITECO: Canis lupus Linnaeus 1758 (documento pdf). Sintetiza la información oficial más relevante de esta especie. https://www.miteco.gob.es/es/biodiversidad/temas/inventarios-nacionales/ieet_mami_canis_lupus_tcm30-99788.pdf

${ }^{158}$ García Ureta, A., op. cit., 33-34.

${ }_{159}$ Vid. web MITECO: Censo 2012-2014 del lobo ibérico (Canis lupus, Linnaeus, 1758) en España.

https://www.miteco.gob.es/en/biodiversidad/temas/inventarios-nacionales/censo_lobo_espana_2012_14pdf_tcm38-197304.pdf

${ }^{160}$ Blanco, J.C., Laso, R., Alonso, O., Diez años tras los lobos madrileños, en revista Quercus, mayo 2021, $12-19$.

178 Derecho Animal. Forum of Animal Law Studies, vol. 12/2
} 
competencia exclusiva: "Legislación básica sobre protección del medio ambiente, sin perjuicio de las facultades de las Comunidades Autónomas de establecer nomas adicionales de protección.” Por su parte, el art. 148.1.9 $\mathrm{CE}$ establece que las CCAA podrán asumir competencias en "la gestión en materia de protección del medio ambiente". Atendiendo al contenido de ambos preceptos constitucionales, puede entenderse que el tema de la protección de la fauna silvestre es un supuesto de competencia legislativa compartida: al Estado le correspondería el establecimiento de unos principios básicos para informar la legislación en la materia sobre protección del medio ambiente; y a las Comunidades Autónomas, la promulgación de la legislación sobre esta materia.

La Ley 42/2007, de 13 de diciembre, del Patrimonio Natural y la Biodiversidad, se considera como una ley básica, con principios básicos fijados por el Estado a cumplir por todas las CCAA. Pero, ¿existe un control real sobre el cumplimiento de estos principios básicos en relación a la protección y gestión del lobo? Una mejor coordinación entre AAPP y una mayor homogeneización de la normativa relacionada con la protección legal del lobo y su gestión, seguramente supondría una mejora sustancial en la conservación de la especie. Si las CCAA cumplieran con el marco normativo comunitario y estatal en materia de protección de la biodiversidad, en nuestro caso, en la protección del lobo, se solucionaría una gran parte de los conflictos actuales.

Es evidente que la Administración General del Estado también tiene su cuota de culpabilidad en el incumplimiento de las obligaciones que la normativa establece. El análisis del funcionamiento de los organismos que configuran la estructura sobre medio ambiente, tanto a nivel estatal como de CCAA, excede el objetivo de este trabajo. Pero este incumplimiento puede percibirse en el hecho de que son las asociaciones y entidades conservacionistas las que interponen demandas ante los órganos judiciales para restablecer la legalidad vigente. Esta última aseveración, hecha sí, con la prudencia de no haber analizado el funcionamiento interno de los organismos implicados y de las actuaciones que hayan podido realizarse desde la Administración General del Estado. Pero las evidencias parece que la confirman.

Todas estas acciones no son posibles sin la participación activa de los poderes públicos, motivo por el cual, si éstos no cambian de actitud, la solución al problema de un tratamiento homogéneo para el lobo en España quizá deba pasar por la modificación o creación de normativa comunitaria. En este caso, podría solicitarse una modificación en el Anexo II de la Directiva Hábitats, como establece el art. 19 de la citada norma, homologando al lobo en todo el Estado español como especie de interés comunitario. Su justificación estaría en la adaptación del Anexo a los nuevos conocimientos científicos sobre el tema y a la situación actual. Más efectivo, y de aplicación directa, sería la aprobación de un Reglamento europeo que optara por una decidida defensa de los grandes carnívoros europeos, que blindara legalmente la protección estricta del lobo.

La coordinación y homogeneización que planteamos no es un capricho, sino una solución jurídica a un problema ecológico. Sin ello, difícilmente puede solucionarse el tema de la conservación del lobo ibérico. Todos los lobos de la Península Ibérica forman una misma comunidad, incluido el lobo ibérico establecido en Portugal ${ }^{161}$. Sin una visión y actuación unitaria, difícilmente se logrará la conservación del lobo. Por esta razón, también es de suma importancia establecer corredores ecológicos para la comunicación entre las distintas áreas loberas de la Península. Esta medida podría adoptarse a través de la Conferencia Sectorial de Medio Ambiente, órgano de cooperación entre Estado y CCAA. Es evidente que son necesarias medidas más ambiciosas que las que se están aplicando si se pretende desatascar la precaria situación del lobo ibérico.

El reciente proyecto de Orden Ministerial para incluir a todas las poblaciones del lobo en el LESPRE, adoptado en febrero de este año en el seno de la Comisión Estatal para el Patrimonio Natural y de la Biodiversidad con el objetivo de modificar el anexo del RD 139/2011, de materializarse, supondría un cambio de paradigma en la consideración jurídica del lobo. No obstante, para que ese cambio sea efectivo, no deben postergarse otras acciones también necesarias, como las ayudas eficaces al sector ganadero o las tendentes a la formación y dotación de medios necesarios para los órganos administrativos competentes en materia de protección de la biodiversidad.

\section{Conclusiones}

Los principales objetivos en la labor de protección del lobo, para la mayoría de los agentes

\footnotetext{
${ }^{161}$ En esta línea, como señala Agustín García Ureta: "El TJUE ha indicado,..., que el estado de conservación de una población en el ámbito nacional o biogeográfico depende de las "repercusiones acumuladas" de las distintas excepciones que afectan a regiones. Cuando las fronteras de un Estado miembro incluyan varias regiones biogreográficas es necesario evaluar tanto el estado de conservación de las poblaciones de la especie de que se trata como el impacto que una medida pueda tener en dicho estado de conservación, "localmente y en todo el territorio de este Estado miembro" o, en su caso de la región biogeográfica de que se trate. Esta exigencia tiene importancia en el caso de las poblaciones del lobo al norte del río Duero, cuya captura esté permitida, al compartirse región biogeográfica con Portugal y encontrarse protegida esta especie en todo el territorio de este Estado miembro de la UE.” Op. cit., 39.
} 
conservacionistas, son la reducción de la conflictividad con los sectores ganadero y cinegético, la mejora de la percepción del lobo por parte de la sociedad y garantizar su protección legal. También son líneas básicas a seguir según estudios científico-técnicos, como el elaborado por el Grupo de Trabajo del Lobo, realizados por órganos dependientes de las AAPP. Estos objetivos pueden abordarse con la implementación de distintas acciones, algunas de la cuales se han ido exponiendo a lo largo del trabajo.

Este primer análisis de la situación del lobo, desde sus vertientes ecológica, social y jurídica, nos conduce a unas conclusiones que pueden concretarse en actuaciones a distintos niveles, todo ello con la intención de lograr una efectiva conservación de la especie. Así, las acciones que creemos podrían ayudar a la conservación del lobo, atendiendo al marco jurídico actual y a los criterios de actuación que deberían exigirse a los poderes públicos, son las que exponemos a continuación.

1. Realizar actuaciones para facilitar la expansión de la especie en territorios donde la población de lobos tiene un carácter endémico o casi nulo. Los corredores ecológicos son parte de esta solución.

2. Necesidad de reintroducción de la especie. La contextualización del lobo en la evolución histórica de la Península Ibérica, aunque sea una aproximación somera, no es para nada gratuita, y tiene sentido desde una perspectiva jurídica. El art. 55.1 de la Ley 42/2007 dice: "Las Administraciones públicas promoverán la reintroducción de las especies de la fauna y flora silvestres autóctonas extinguidas, incluyendo aquéllas desaparecidas de todo el medio natural español en tiempos históricos, sobre las que existan referencias escritas fidedignas, y de las que aún existan poblaciones en otros lugares o en cautividad, especialmente cuando estas reintroducciones contribuyan al restablecimiento del estado de conservación favorable de especies o hábitats de interés comunitario." La norma establece un requisito de procedimiento: no podrán autorizarse proyectos de reintroducción de especies no presentes en estado silvestre en el territorio español, que no estén incluidas en un Listado de especies extinguidas en todo el medio natural español. $Y$ ese no es el caso del lobo ibérico. En el punto 2 del citado precepto, se señala que: "Cualquier Administración pública, o cualquier persona física o jurídica de derecho privado podrá solicitar a la Dirección General competente en medio natural del Ministerio de Agricultura, Alimentación y Medio Ambiente la iniciación del procedimiento de inclusión de una especie en este Listado, acompañando a la correspondiente solicitud, una argumentación científica justificativa de su carácter autóctono y de su presencia estable en estado silvestre en el territorio español de forma previa a su extinción." La historia, tal vez, pueda servir de referente para justificar una vía legítima de apoyo en la defensa del lobo. También el art. 13 del RD 139/2011 prevé la posible reintroducción de especies extintas. Pero para que esta vía pueda tener éxito es imprescindible la implicación de los poderes públicos, ya que el art. 55, en su punto 4, apunta la necesidad de autorización preceptiva de la Administración General del Estado o de la comunidad autónoma, en sus competencias, para aplicar proyectos de reintroducción de especies silvestres autóctonas extinguidas en determinados territorios. No se trata de una reintroducción en todos los territorios ocupados en siglos pasados, sino en áreas donde sea aconsejable desde un punto de vista científico-técnico.

3. Limitar o cesar la actividad cinegética sobre el lobo. La llamada caza deportiva del lobo es algo anacrónico, que no cuenta con argumentos válidos en la actualidad. El lobo vivo puede ser tan productivo para el mundo rural como su caza; además, es elemento benefactor del ecosistema, controlando a otros predadores, y cumpliendo con una función sanitaria entre la fauna silvestre. Por todo ello, es necesario que se cese en el empeño de gestionar al lobo como especie cinegética. Se puede apostar por otras vías alternativas, como potenciar el turismo rural y de observación de la naturaleza. En caso de daños concretos al sector ganadero, siempre existe la posibilidad de efectuar extracciones de ejemplares del medio natural mediante agentes de las AAPP.

4. Apoyo al sector ganadero. Evidentemente, la ayuda se dirigiría a las explotaciones, en su mayoría de reducido tamaño, en las que la especie produzca daños de cierta cuantía; ayudas económicas tanto para indemnizar daños como para prevenirlos. La información y la formación de carácter científicotécnico para el sector es una necesidad, a la vez que una obligación de los poderes públicos.

5. Armonización legal global. Sin una armonización legal y una regulación global en todos los niveles (comunitario, estatal y autonómico) es poco viable hablar de una preservación o conservación de las especies de la fauna silvestre. Y, menos aún, hablar de una coexistencia pacífica y que esas especies vuelvan a ocupar territorios que hace pocas décadas eran sus hábitats.

Atendiendo a la máxima que los problemas deben abordarse en su justa medida, a problemas globales debemos responder con soluciones globales. A la desaparición de una especie de su espacio natural debemos responder con una regulación global. Sin este requisito no se puede lograr la plena recuperación de una 
especie. Ya hemos visto que, a lo largo de la historia, el lobo no ha representado ningún problema capital para el sector ganadero, como tampoco es un peligro para la vida humana, para las personas que se desenvuelven en el mundo rural, sobre todo si se les deja actuar en su espacio vital, sin pretender interactuar con él. La percepción negativa sobre la especie, que a lo largo de tantos siglos se ha consolidado en nuestra sociedad, debe cambiar para hacer justicia a la realidad. Al contrario, el lobo sí supone un elemento esencial para un sano equilibrio ecológico.

Por todo ello, es necesaria una solución global para el problema de la desaparición del lobo de toda la Península Ibérica. Aunque no sea factible la reintroducir al lobo en todos los territorios que ocupó en los últimos siglos, por evidentes efectos antropogénicos, sí se debería exigir a las AAPP su protección en toda la Península, para posibilitar su expansión hacia otros territorios de forma natural y sin necesidad de programas de reintroducción.

Como ya apuntábamos, tal vez sea necesaria la elaboración de un Reglamento comunitario, una norma de aplicación directa en toda la UE, donde se proteja a las grandes especies carnívoras europeas, y no normas que deban transponerse a los distintos ordenamientos jurídicos estatales. Por desgracia, el contexto medio ambiental desde la promulgación de la Directiva Hábitats ha cambiado sustancialmente, y no para bien en cuanto al lobo. Lo que en aquel momento parecían objetivos a lograr a largo plazo se han convertido en necesidades a corto plazo. Cambio climático y pérdida de biodiversidad, elementos que a menudo se perciben como separados pero que están profundamente interrelacionados, hacen necesaria una normativa más actualizada. La visión global de la especie humana y la naturaleza, que proponía ya hace más de 40 años el Dr. Félix Rodríguez de la Fuente, la necesidad de un Derecho Global para los animales que defiende la Dra. Anne Peters, o de un Tratado Internacional para el Bienestar Animal que expone el Dr. David Favre, son razones a añadir a la necesidad de cambios fundamentales en el campo del Derecho si se pretende combatir la deriva a la que se aboca nuestro planeta y, por ende, la Humanidad.

Unas reflexiones generales pueden ayudar a entender el problema que se plantea, más allá de la percepción que visionamos desde el área del Derecho.

Es una opinión generalizada dentro de los colectivos a favor de mejorar el trato humano con los animales que, hasta hace relativamente poco tiempo, se ha sobrevalorado la atención prestada a la fauna silvestre y a su protección. La desatención a la protección y el bienestar de muchas de las especies animales domesticadas ha sido una realidad. No obstante, la fauna silvestre cuenta con un hándicap negativo específico, en especial las especies amenazadas, y es la posibilidad que en un corto espacio de tiempo dejen de ser un problema para la conservación, porque habrán dejado de existir. La Dra. Giménez-Candela también expone la necesidad de adaptarse a la nueva situación:

Los gobiernos son conscientes, desde ahora, de que no resulta defendible volver la vista para otro lado y seguir permitiendo prácticas como la caza deportiva que resultan abrumadoramente rechazadas por la ciudadanía global. Las normas legales precisan de una revisión, a la luz de las nuevas necesidades de nuestro ya escaso patrimonio natural, justamente el que compartimos con los animales. ${ }^{162}$

Estudiosos de la evolución de la vida en nuestro planeta hablan de cinco grandes extinciones masivas, la más grave, a finales del Pérmico. En la actualidad, apuntan que ya ha comenzado la sexta: la extinción masiva del Holoceno, período geológico actual, el cual comenzó hace 11700 años. La creciente disminución en el número de especies es un hecho comprobado ${ }^{163}$.

La actividad de los humanos modernos, con unos 200000 años de antigüedad, ha provocado que nuestro planeta haya experimentado múltiples cambios, acentuados en los últimos siglos. La población humana ha pasado de los 1.000 millones del año 1800 a superar los 6.000 millones en el año 2000. En el año 2009, la población urbana ha superado en número a la rural; y algunas estimaciones afirman que en 2100 la población del planeta puede llegar a los 10.000 millones $^{164}$.

Steve Parker, zoólogo, señala que:

...los entornos colonizados por los humanos, tales como los dedicados a la expansión urbana, a las tierras de cultivo y a la ganadería, tienden a destruir los hábitats naturales. (...) Allí donde se expande el ser humano por el mundo, le siguen grupos semejantes de animales y plantas: los gatos domésticos, los perros, las ratas de alcantarilla, las ortigas, los helechos del género Pteridium y ciertos tipos de líquenes, así como una gran cantidad de microbios. Estas especies prosperan en las condiciones que propician la presencia y el desarrollo humanos. Sin embargo, entorpecen a toda una serie de especies

\footnotetext{
162 Giménez-Candela, T., op. cit., 121.

163 Parker, S., op. cit., 554.

${ }^{164}$ Ibid., 555.
} 
locales. ${ }^{165}$

Creo adecuado sacar a colación unas palabras de Steve Parker para comprender la responsabilidad de nuestra sociedad, y lo que nos jugamos como especie, en relación a la protección y conservación de las especies silvestres: "Sería fascinante poder viajar unos millones de años al futuro y contemplar la época en la que vivimos para ver si la sexta extinción resulta la más drástica de todas y el tiempo que tarda en recuperarse la biodiversidad a pesar de los humanos, o después de su desaparición."166

Debemos lograr que todos los agentes implicados en el tema reflexionen sobre la necesidad de cambiar el enfoque del problema y bucear en busca de soluciones en consonancia con los tiempos actuales, no con referentes equívocos del pasado. Si situamos al lobo en el lugar justo que le corresponde dentro de la problemática del mundo rural, habremos dado un primer paso esencial. En demasiadas ocasiones, los referentes considerados por los agentes implicados no son exactos, sino falsos, y deben ser cambiados. La historia oral de las gentes del mundo rural, por muy respetable que sea, no va siempre de la mano de la realidad histórica. Sin una interpretación crítica es complicado avanzar hacia una sociedad que se ha dado unos principios y valores distintos a los que podían encontrarse en la cultura o tradición popular. Y este hecho también tiene que tomarse en consideración a la hora de evaluar al lobo. Giménez-Candela apunta que:

Cuando se enarbola la tradición para justificar actos que podrían ser prohibidos o castigados, si no estuvieran protegidos por el calificativo de tradicionales, algo no funciona. Cuando la tradición se escribe con mayúscula, para blindarse contra el sano y necesario ejercicio de la crítica, algo no funciona. ${ }^{167}$

La defensa del lobo se ha convertido en estos últimos años en un fenómeno social, y no solo de pequeños grupos activistas en defensa de los animales. No obstante, hace falta que se convierta en una prioridad política, de estado y comunitaria, para que ese deseo social, justificado por la actual situación de la biodiversidad del planeta, pueda hacerse efectivo.

La defensa de los grandes carnívoros, por desgracia, no va a ser algo excepcional y, más pronto que tarde, la sociedad deberá defender a los mismos herbívoros de la extinción. Un reciente artículo científico señala la triste realidad de que las especies herbívoras presentan un mayor riesgo de extinción entre mamíferos, aves y reptiles ${ }^{168}$. Por tanto, es también evidente la necesidad de una profunda reestructuración de los planteamientos actuales del sector cinegético y de las políticas de gestión del medio ambiente.

Las palabras de unos reconocidos científicos nos pueden ayudar a perseverar en nuestra tarea de lograr un marco jurídico mejor para el mundo animal, del cual nosotros también formamos parte. Karl R. Popper, filósofo, y Konrad Lorenz, etólogo, amigos de infancia, ambos hombres de ciencia, mantuvieron una conversación informal y amistosa en Altenberg, en 1983, ante las cámaras de televisión, transcrita en un libro ${ }^{169}$. Durante la misma, el Dr. Lorenz habló sobre el libro en el que trabajaba, La decadencia de lo humano, y señaló la existencia de peligros para el futuro de la Humanidad. El Dr. Popper expresó su percepción de que la refutación de un optimismo demasiado ingenuo puede convertirse en una invitación a ver nuevas posibilidades. Así dice: “...yo veo el mayor peligro precisamente en el pesimismo, esto es, en la continua pretensión de decirles a los jóvenes que están viviendo en un mundo malo. (...) Desde un punto de vista histórico, vivimos, a mi juicio, en el mejor mundo que ha existido nunca. Naturalmente que es un mundo malo, porque hay otro mejor y porque la vida nos incita a buscar mejores mundos. Y a nosotros nos toca continuar esa búsqueda de un mundo mejor." El Dr. Lorenz acaba la conversación diciendo: "Nada ha existido ya y todo es posible."

\section{Bibliografía}

- ALONSO GARCÍA, E., El artículo 13 del Tratado de Funcionamiento de la Unión Europea: Los animales como seres sensibles (sentientes) a la luz de la jurisprudencia del Tribunal de Justicia de la Unión Europea, en GIMÉNEZ-CANDELA, T., FAVRE, D., Animales y Derecho (Valencia 2015)

- ATWOOD, T.B., et al., Herbivores at thehighest risk of extinction among mammals, birds, and reptiles, en Science Advances, (2020; 6), (DOI: 10.1126/sciadv.abb8458)

\footnotetext{
165 Ibid., 555.

166 Ibid., 555.

${ }^{167}$ Giménez-Candela, T., op. cit., 104.

168 Atwood, T.B. et al., Herbivores at the highest risk of extinction among mammals, birds, and reptiles, en Science Advances, 6 (2020).

${ }^{169}$ Popper, K.R., Lorenz, K., El Porvenir está abierto, edición de Franz Kreuzer (Barcelona 2020), 57-60.

182 Derecho Animal. Forum of Animal Law Studies, vol. 12/2
} 
- BLANCO, J.C., et al., Estrategia para la conservación y la gestión del lobo (Canis lupus) en España, Grupo de Trabajo del Lobo, Ministerio de Medio Ambiente (Madrid 2006)

- BLANCO, J.C., LASO, R., ALONSO, O., Diez años tras los lobos madrileños, revista Quercus, núm. 423, mayo 2021, 12-19

- BLASCO HEDO, E., Blasco Hedo, E., Comentario a la Sentencia del Tribunal Superior de Justicia de Castilla y León, de 12 de diciembre de 2019, en Actualidad Jurídica Ambiental: https://www.actualidadjuridicaambiental.com/jurisprudencia-al-dia-castilla-y-leon-planes-lobocaza/

- BLASCO HEDO, E., Comentario a la STSJ CL, de 25 de enero de 2018, en Actualidad Jurídica Ambiental: https://www.actualidadjuridicaambiental.com/jurisprudencia-al-dia-castilla-y-leonplan-de-conservacion-y-gestion-del-lobo/

- BLASCO HEDO, E., Comentario a la STSJ CL de 12 de febrero de 2018, en Actualidad Jurídica Ambiental: https://www.actualidadjuridicaambiental.com/jurisprudencia-al-dia-castilla-y-leonplan-de-aprovechamientos-comarcales-del-lobo/

- BLASCO HEDO, E., Suspensión provisional de la actividad cinegética por la estimación judicial de una medida cautelar versus modificación de la Ley de Caza de Castilla y León que autoriza su ejercicio, Actualidad Jurídica Ambiental, n. 89, 2019, 47-61

- BOITANI, L., FRANCISCI, F., CIUCCI, P., ANDREOLI, G., The ecology and behavior of feral dogs: A case study from central Italy, en SERPELL, J., The domestic dog. Its evolution, behavior and interactions with people, (New York 2016) 342-368, (DOI: 10.1017/9781139161800.017)

- CASADO CASADO, L., Sentencia del Tribunal Supremo de 23 de noviembre de 2020, Actualidad Jurídica Ambiental, n. 108, 2021, 115-120

- CLUTTON-BROCK, J, Origins of the dog: The archaeological evidence, en SERPELL, J., The domestic dog. Its evolution, behavior and interactions with people, (New York 2016) 7-21, (DOI: 10.1017/9781139161800.002)

- COPPINGER, R., COPPINGER, L., Perros. Una nueva interpretación sobre su origen, comportamiento y evolución, (Madrid 2004)

- DARWIN, Ch., El origen de las especies, vol. I, (Barcelona 1979)

- DEL RIEGO CELADA, L., GALHANO ALVES, J., Contos y cuentos de lobos. Recorrido por los relatos loberos de Sanabria y Tras os Montes, (Zamora 2006)

- DIAMOND, J., Armas, gérmenes y acero. Breve historia de la humanidad en los últimos trece mil años, (Barcelona 2018)

- DURÀ ALEMAÑ, C.J., Comentario a la Sentencia 148/2020, de 22 de octubre de 2020, del Pleno del Tribunal Constitucional, en Actualidad Jurídica Ambiental: https://www.actualidadjuridicaambiental.com/jurisprudencia-al-dia-tribunal-constitucionalcastilla-y-leon-caza/

- DURÀ ALEMAÑ, C. J., Comentario a la Ley 7/2020, de 2 de julio, de la Agencia de la Naturaleza de Cataluña, en Actualidad Jurídica Ambiental: https://www.actualidadjuridicaambiental.com/legislacion-al-dia-cataluna-agencia-de-la-naturalezade-cataluna/

- FAVRE, D., An International Treaty for Animal Welfare, en Animal Law and Welfare International Perspectives, 87-106, (DOI: 10.1007/978-3-319-26818-7_5 (2016)

- FAVRE, D., Humane Treatment of Wildlife, en Animal Suffering: From Science to Law, 305-320, (Toronto 2013)

- FERNÁNDEZ ALBALADEJO, P., La crisis de la monarquía, en Fontana, J. y Villares, R., Historia de España, vol. 4, (2017)

- FONTANA, J., La época del liberalismo, en Fontana, J. y Villares, R., Historia de España, vol. 6, (2017)

- FOSSAS, E., PÉREZ FRANCESCH, LL., Lliçons de Dret Constitucional, (Barcelona 2001)

- GARCÍA MARTÍN, L., Régimen jurídico para la protección del lobo ibérico y su impacto en el Parque Nacional de Picos de Europa, TFG, Facultad de Derecho, Universidad de León, 2017

- GARCÍA MARTÍN, L., Régimen jurídico para la protección del lobo ibérico, Revista Aranzadi de Derecho Ambiental, núm. 37, 2017, 259-291

- GARCÍA MARTIN, L., El estatus jurídico del lobo ibérico en el punto de mira: un cambio de paradigma en Castilla y León, Revista jurídica de Castilla y León, núm. 50, 2020, 99-138

- GARCÍA MARTÍN, L., La regulación del lobo en Castilla y León vuelve a ser noticia, Revista Aranzadi de Derecho Ambiental, núm. 46, 2020, 151-160 
- GARCÍA URETA, A., Consideraciones sobre el Régimen Jurídico de la Unión Europea e Internacional de aplicación al lobo (Canis lupus) y su traslación al Derecho español, Actualidad Jurídica Ambiental, n. 111, 2021, 1-40.

- GIMÉNEZ-CANDELA, T., Transición animal en España (Valencia, 2020)

- GRANDE DEL BRÍO, R., El lobo ibérico. Biología, ecología y comportamiento, (Salamanca 2015)

- GREGER, L. et al., Rethinking dog domestication by integrating genetics, archeology, and biogeography, en Proceedings of the National Academy of Sciencies USA, 109(23), (junio 2012), (DOI: 10.1073/pnas.1203005109)

- HAVA GARCÍA, E., La tutela penal de los animales, (Valencia, 2009), 17-22, (DOI: 10.17345/rcda1081)

- LIVI BACCI, M., Historia mínima de la población mundial, (Barcelona 2019)

- LÓPEZ-BAO, J.V., FLEURKE, F., CHAPRON, G., TROUWBORST, A., Legal obligations regarding populations on the verge of extinction in Europe: Conservation, Restoration, Recolonization, Reintroduction, en Biological Conservation 227 (2018), 319-325, (DOI: 10.1016/j.biocon.2018.09.027)

- LORENZ, K., Cuando el hombre encontró al perro, (Barcelona 2010)

- MANTECA VILANOVA, X., Etología veterinaria, (Barcelona 2009)

- MANZANO MORENO, E., Épocas Medievales, en Fontana, J. y Villares, R., Historia de España, vol. 2, (2017)

- MORA RUIZ, M., Comentario a la Sentencia del Tribunal Supremo de 11 de febrero de 2020, en Actualidad Jurídica Ambiental: https://www.actualidadjuridicaambiental.com/jurisprudencia-aldia-tribunal-supremo-proteccion-de-especies-responsabilidad-patrimonial/

- MULÀ ARRIBAS, ANNA, Derecho ambiental versus derecho animal, en GIMÉNEZ-CANDELA, T., FAVRE, D., Animales y Derecho (Valencia 2015), 329-338

- NIETO MACEÍN, D., Etología del lobo y del perro, (Valencia 2008)

- NIETO MACEÍN, D., Lo que el lobo sabe. Ecoetología y conservación del lobo, (Valencia 2016)

- OSTERHAMMEL, J., La transformación del mundo. Una historia global del siglo XIX, (Barcelona 2015)

- OSTERHAMMEL, J., El vuelo del águila, (Barcelona 2018)

- PARKER, S., Evolución. Toda la historia, (Barcelona 2016)

- PETERS, A., Global Animal Law: What it is and why we need it, en Transnational Envirommental Law, 5(1), 9-23, (Cambridge 2016), (DOI: 10.1017/s2047102516000066)

- PLÁCIDO, D., Hispania Antigua, en Fontana, J. y Villares, R., Historia de España, vol. 1, (2017)

- POPPER, K.R., LORENZ, K., El Porvenir está abierto, edición de Franz Kreuzer (Barcelona 2020).

- RODRÍGUEZ DE LA FUENTE, F., Protection of the wolf in Spain. Notes on a public awareness campaign, en Proceedings of the First Working Meeting of Wolf Specialists and of the First International Conference on Conservation of the Wolf, (Estocolmo 1973)

- RODRÍGUEZ DE LA FUENTE, F., Cuadernos de Campo. El lobo, (Barcelona 1978)

- SAStRE, N., Vilà, C., SAlinAS, M., BOlOGOV, V.V., URIOS, V., SANCHEZ, A., FRANCINO, O., RAMIREZ, O., "Signatures of demographic bottlenecks in European wolf populations", Conservation Genetics, 12 (2011), 701-712, (DOI: 10.1007/s10592-010-0177-6)

- TAMAMES, R., Estructura económica de España, (Madrid 1990)

- URIOS, V., VILÀ, C., CASTROVIEJO, J., Estudio de la incidencia real de la depredación del lobo en la ganadería comparando dos métodos distintos, en Revista Galemys 12, (Málaga 2000)

- WALLERSTEIN, I., El moderno sistema mundial I, (Madrid 2016)

\section{Fuentes jurídicas}

\section{Instrumentos internacionales}

- Declaración de la Conferencia de la ONU sobre el Medio Humano (Oslo, 1972), https://undocs.org/es/A/CONF.48/14/Rev.1

- Convenio sobre la Diversidad Biológica (Río de Janeiro, 1992), https://www.cbd.int/doc/legal/cbdes.pdf

- Lista Roja de UICN, https://www.iucnredlist.org/es/ 


\section{Unión Europea}

- Decisión del Consejo, de 3 de diciembre de 1981, referente a la celebración del Convenio relativo a la conservación de la vida silvestre y del medio natural de Europa (82/72/CEE), (Convenio de Berna, 1979), https://www.boe.es/buscar/doc.php?id=DOUE-L-1982-80052

- Directiva 92/43/CEE del Consejo, de 21 de mayo de 1992, relativa a la conservación de los hábitats naturales y de la fauna y flora silvestres, https://www.boe.es/buscar/doc.php?id=DOUE-L-199281200

- Directiva 2009/147/CE, del Parlamento Europeo y del Consejo, de 30 de noviembre de 2009, relativa a la conservación de aves silvestres, https://www.boe.es/buscar/doc.php?id=DOUE-L$2010-80052$

\section{España}

- Constitución española de 1978, https://www.boe.es/buscar/pdf/1978/BOE-A-1978-31229consolidado.pdf

- Instrumento de ratificación del Convenio relativo a la conservación de la vida silvestre y del medio natural en Europa, hecho en Berna el 19 de septiembre de 1979, https://www.boe.es/buscar/doc.php?id=BOE-A-1986-25961

- Ley 4/1989, de 27 de marzo, de Conservación de los Espacios Naturales y de la Flora y Fauna Silvestres, https://www.boe.es/boe/dias/1989/03/28/pdfs/A08262-08269.pdf

- Ley Orgánica 10/1995, de 23 de noviembre, del Código Penal, https://www.boe.es/buscar/pdf/1995/BOE-A-1995-25444-consolidado.pdf

- Ley 42/2007, de 13 de diciembre, del Patrimonio Natural y la Biodiversidad, https://www.boe.es/buscar/pdf/2007/BOE-A-2007-21490-consolidado.pdf

- Real Decreto 1424/2008, de 14 de agosto, por el que se determinan la composición y las funciones de la Comisión Estatal para el Patrimonio Natural y la Biodiversidad, se dictan las normas que regulan su funcionamiento y se establecen los comités especializados adscritos a la misma, https://www.boe.es/buscar/act.php?id=BOE-A-2008-14855 https://www.boe.es/buscar/pdf/2008/BOE-A-2008-14855-consolidado.pdf

- Real Decreto 948/2009, de 5 de junio, por el que se determinan la composición, las funciones y las normas de funcionamiento del Consejo Estatal para el Patrimonio Natural y la Biodiversidad, https://www.boe.es/buscar/pdf/2009/BOE-A-2009-10221-consolidado.pdf https://www.boe.es/buscar/doc.php?id=BOE-A-2009-10221

- Real Decreto 139/2011, de 4 de febrero, para el desarrollo del Listado de Especies Silvestres en Régimen de Protección Especial y del Catálogo Español de Especies Amenazadas, https://www.boe.es/buscar/pdf/2011/BOE-A-2011-3582-consolidado.pdf

- Real Decreto 1274/2011, de 16 de septiembre, por el que se aprueba el Plan estratégico del patrimonio natural y de la biodiversidad 2011-2017, en aplicación de la Ley 42/2007, de 13 de diciembre, del Patrimonio Natural y de la Biodiversidad, https://www.boe.es/buscar/pdf/2011/BOEA-2011-15363-consolidado.pdf

- Real Decreto 1015/2013, de 20 de diciembre, por el que se modifican los anexos I, II y V de la Ley 42/2007, de 13 de diciembre, del Patrimonio Natural y de la Biodiversidad, https://www.boe.es/buscar/doc.php?id=BOE-A-2013-13432

- Resolución de 6 de marzo de 2017, de la Dirección General de Calidad y Evaluación Ambiental y Medio Natural, por la que se publica el Acuerdo del Consejo de Ministros de 24 de febrero de 2017, por el que se aprueban los criterios orientadores para la inclusión de taxones y poblaciones en el Catálogo Español de Especies Amenazadas, https://www.boe.es/boe/dias/2017/03/17/pdfs/BOE-A2017-2977.pdf

- Orden TEC/596/2019, de 8 de abril, por la que se modifica el anexo del RD 139/2011, de 4 de febrero, para el desarrollo del Listado de Especies Silvestres en Régimen de Protección Especial y del Catálogo de Especies Amenazadas, https://www.boe.es/boe/dias/2019/06/05/pdfs/BOE-A2019-8317.pdf

- Orden TEC/596/2019, de 8 de abril, por la que se modifica el anexo del RD 139/2011, de 4 de febrero, para el desarrollo del Listado de Especies Silvestres en Régimen de Protección Especial y del Catálogo de Especies Amenazadas, https://www.boe.es/boe/dias/2019/06/05/pdfs/BOE-A- 
2019-8317.pdf

\section{Comunidades Autónomas}

\section{Andalucía}

- Ley 8/2003 de la Flora y Fauna Silvestre de Andalucía, https://www.juntadeandalucia.es/boja/2003/218/1

- Aragón

- Decreto 181/2005, de 6 de septiembre, del Gobierno de Aragón, por el que se modifica parcialmente el Decreto 49/1995, de 28 de marzo, de la Diputación General de Aragón, por el que se regula el Catálogo de Especies Amenazadas de Aragón, https://boa.vlex.es/vid/parcialmente-catalogoespecies-amenazadas-18034623

\section{Asturias}

- Decreto 23/2015, de 25 de marzo, por el que se aprueba el II Plan de Gestión del Lobo en el Principado de Asturias, https://sede.asturias.es/bopa/2015/04/06/2015-05930.pdf

\section{Cantabria}

- Orden MED/5/2019, de 28 de marzo, por la que se aprueba el Plan de Gestión del Lobo en Cantabria, https://aplicacionesweb.cantabria.es/boces/verAnuncioAction.do?idAnuBlob=337284

\section{Castilla - La Mancha}

- Decreto 33/1998, de 5 de mayo, por el que crea el Catálogo Regional de Especies Amenazadas de Castilla-La Mancha, https://derechoanimal.info/sites/default/files/legacyfiles/bbdd/Documentos/636.pdf

- Decreto 22/2016, de 10 de mayo de 2016, por el que se modifica el Catálogo Regional de Especies Amenazadas, aprobado por el Decreto 33/1998, de 5 de mayo, por el que crea el Catálogo Regional de Especies Amenazadas de Castilla-La Mancha, https://docm.castillalamancha.es/portaldocm/descargarArchivo.do?ruta=2016/05/13/pdf/2016_522 0.pdf\&tipo=rutaDocm

\section{Castilla y León}

- Ley 4/1996, de 12 de julio, de Caza de Castilla y León, https://www.boe.es/buscar/pdf/1996/BOEA-1996-19866-consolidado.pdf

- Ley 4/2006, de 25 de mayo, de modificación de la Ley 4/1996, de 12 de julio, de Caza de Castilla y León, https://www.boe.es/boe/dias/2006/06/26/pdfs/A24042-24043.pdf

- Censo regional del lobo ibérico (Canis lupus) en la Comunidad de Castilla y León 2012-2013, https://medioambiente.jcyl.es/web/jcyl/MedioAmbiente/es/Plantilla100Detalle/1246988359553/_ _ 1284417422849/Comunicacion?plantillaObligatoria=PlantillaContenidoNoticiaHome

- Decreto 32/2015, de 30 de abril, por el que se regula la conservación de las especies cinegéticas de Castilla y León, su aprovechamiento sostenible y el control poblacional de la fauna silvestre, http://bocyl.jcyl.es/boletines/2015/05/04/pdf/BOCYL-D-04052015-3.pdf

- Decreto 14/2016, de 19 de mayo, por el que se aprueba el Plan de Conservación y Gestión del lobo en Castilla y León, https://medioambiente.jcyl.es/web/jcyl/MedioAmbiente/es/Plantilla100/1284749963369/___

- Resolución de 29 de julio de 2016, de la Dirección General del Medio Natural, Consejería de Fomento y Medio Ambiente de la Junta de Castilla y León, por la que se aprueba el Plan de aprovechamientos comarcales de lobo en los terrenos cinegéticos situaciones al norte del Río Duero en Castilla y león para las temporadas 2016/2017, 2017/2018 y 2018/2019, http://bocyl.jcyl.es/boletines/2016/08/08/pdf/BOCYL-D-08082016-5.pdf

- Resolución de 26 de julio de 2017, de la Dirección General del medio Natural, por la que se modifica la Resolución de 29 de julio de 2017, de la Dirección General del Medio Natural, por la que se 
modifica la Resolución de 29 de julio de 2016, por la que se aprueba el Plan de Aprovechamientos Comarcales de Lobo en los terrenos cinegéticos situados al norte del Río Duero en Castilla y León para las temporadas 2016/2017,2017/2018y2018/2019, http://bocyl.jcyl.es/boletines/2017/08/04/pdf/BOCYL-D-04082017-30.pdf

- Decreto 10/2018, de 26 de abril, por el que se modifica el Decreto 32/2015, de 30 de abril, por el que se regula la conservación de las especies cinegéticas de Castilla y León, su aprovechamiento sostenible y el control poblacional de la fauna silvestre, http://bocyl.jcyl.es/boletines/2018/04/30/pdf/BOCYL-D-30042018-3.pdf

- Ley 9/2019, de 28 de marzo, de modificación de la Ley 4/1996, de 12 de julio, de Caza en la Comunidad Autónoma de Castilla y León, https://www.boe.es/buscar/pdf/1996/BOE-A-199619866-consolidado.pdf

- Resolución de 9 de octubre de 2019, de la Dirección General del Patrimonio Natural y Política Forestal, por la que se aprueba el Plan de aprovechamientos comarcales de lobo en los terrenos cinegéticos situados al norte del Río Duero en Castilla y León para las temporadas 2019/2020, 2020/2021 y 2021/2022, http://bocyl.jcyl.es/boletines/2019/10/23/pdf/BOCYL-D-23102019-21.pdf

- Comunicado de 3 de enero de 2020, de la Consejería de Fomento y Medio Ambiente de la Comunidad de Castilla y León, https://comunicacion.jcyl.es/web/jcyl/Comunicacion/es/Plantilla100Detalle/1281372051501/_128 4919448806/Comunicacion

\section{Cataluña}

- Decreto Legislativo $2 / 2008$, de 15 de abril, por el cual se aprueba el Texto refundido de la Ley de protección de los animales, https://www.boe.es/buscar/pdf/2008/DOGC-f-2008-90016consolidado.pdf

- Ley 7/2020, de 2 de julio, de la Agencia de la Naturaleza de Cataluña, https://portaldogc.gencat.cat/utilsEADOP/PDF/8171/1803458.pdf

\section{Extremadura}

- Ley 8/1998, de 26 de junio, de Conservación de la Naturaleza y de Espacios Naturales de Extremadura, https://www.boe.es/buscar/pdf/1998/BOE-A-1998-20256-consolidado.pdf

- Decreto 78/2018, de 5 de junio, por el que se modifica el Decreto37/2001, de 6 de marzo, por el que se regula el Catálogo Regional de Especies Amenazadas de Extremadura, http://doe.gobex.es/pdfs/doe/2018/1120o/18040091.pdf

\section{Galicia}

- Decreto 297/2008, de 30 de diciembre, por el que se aprueba el Plan de gestión del lobo en Galicia, https://www.xunta.gal/dog/Publicados/2009/20090120/Anuncio238A_es.html

- Ley 13/2013, de 23 de diciembre, de caza de Galicia, https://www.xunta.gal/dog/Publicados/2014/20140108/AnuncioC3B0-301213-0002_es.pdf

\section{La Rioja}

- Decreto 59/1998, de 9 de octubre, por el que se crea y regula el Catálogo Regional de Especies Amenazadas de la Flora y Silvestre, https://ias1.larioja.org/cex/sistemas/GenericoServlet?servlet=cex.sistemas.dyn.portal.ImgServletSi s\&code= oumCvWIgBUF61Chv9ZDgP\%2FhXhSM\%2FFmcHB\%2B3R7kIk3DMH5h3TVkJMOg IAFw6X7X0oxVWa9cUmjPoz\%0AIuPHH0wEcyN\%2B66VFV1pP

- Decreto 17/2004, de 27 de febrero, por el que se aprueba el Reglamento de Caza de La Rioja, https://ias1.larioja.org/cex/sistemas/GenericoServlet?servlet=cex.sistemas.dyn.portal.ImgServletSi s\&code= oumCvWIgBUF61Chv9ZDgP\%2FhXhSM\%2FFmcHMquqsNYvm4oH5h3TVkJMOgIA Fw6X7X0oxVWa9cUmjPqH\%0AwmTpOZY5YSN\%2B66VFV1pP 
- Decreto 18/1992, de 26 de marzo, por el que se aprueba el Catálogo Regional de especies amenazadas de fauna y flora silvestres, http://www.madrid.org/wleg_pub/secure/normativas/contenidoNormativa.jsf?opcion=VerHtml\&n mnorma $=1165 \&$ cdestado $=$ P\#no-back-button

\section{Murcia}

- Ley $7 / 1995$, de 21 de abril, de la fauna silvestre, caza y pesca fluvial, https://www.boe.es/buscar/pdf/1995/BOE-A-1995-13301-consolidado.pdf

\section{Navarra}

- Decreto Foral 254/2019, de 16 de octubre, por el que se establece el Listado navarro de especies silvestres en régimen de protección especial, se establece un nuevo Catálogo de especies de flora amenazadas de Navarra y se actualiza el Catálogo de especies de fauna amenazadas de Navarra, https://bon.navarra.es/es/anuncio/-/texto/2019/216/6

\section{País Vasco}

- Decreto 167/1996, de 9 de julio, por el que se regula el Catálogo Vasco de Especies Amenazadas de la Fauna y Flora, Silvestre y Marina, https://www.legegunea.euskadi.eus/eli/es$\mathrm{pv} / \mathrm{d} / 1996 / 07 / 09 / 167 / \mathrm{dof} / \mathrm{spa} / \mathrm{html} / \mathrm{x} 59$-contfich/es/

- Orden de 2 de marzo de 2020, del Consejero de Medio Ambiente, Planificación Territorial y Vivienda, por la que se modifica el Catálogo Vasco de Especies Amenazadas de Fauna y Flora Silvestre y Marina, https:/www.legegunea.euskadi.eus/eli/espv/o/2020/03/02/(2)/dof/spa/html/x59-contfich/es/

\section{Comunidad Valenciana}

- Decreto 32/2004, de 27 de febrero, del Consell de la Generalitat, por el que se crea y regula el Catálogo Valenciano de Especies de Fauna Amenazadas, y se establecen categorías y normas para su protección, https://www.dogv.gva.es/portal/ficha_disposicion_pc.jsp?sig=0973/2004\&L=1

\section{Jurisprudencia}

- Sentencia no 49/2018, del Tribunal Superior de Justicia de Castilla y León, de 25 de enero de 2018; https://www.poderjudicial.es/search/AN/openDocument/ca93af6829d2211d/20180315

- Sentencia ${ }^{\circ} 132 / 2018$, del Tribunal Superior de Justicia de Castilla y León, de 12 de febrero de 2018; https://www.poderjudicial.es/search/AN/openDocument/9dba92482f30e831/20180423

- Auto de la Sala de lo Contencioso Administrativo del Tribunal Superior de Justicia de Castilla y León (Valladolid), de 21 de febrero de 2019; file://C:/Users/user/AppData/Local/Temp/TSJCyL\%20auto\%20Contencioso\%2021\%20feb\%202 019.pdf

- Sentencia $N^{0} 1458 / 2019$, del Tribunal Superior de Justicia de Castilla-León, de 12 de diciembre de 2019; http://www.poderjudicial.es/search/AN/openDocument/5bf44fa36a2b56a3/20200312

- Sentencia 148/2020, del Tribunal Constitucional, de 22 de octubre de 2020. Recurso de inconstitucionalidad 3993-2019. Interpuesto por el Defensor del Pueblo en relación con diversos preceptos de la Ley 9/2019, de 28 de marzo, de modificación de la Ley 4/1996, de 12 de julio, de caza en la Comunidad Autónoma de Castilla y León. Competencias en materia de caza y protección ambiental y leyes singulares autoaplicativas: constitucionalidad de los preceptos legales autonómicos relativos a la clasificación de especies cinegéticas y determinación de los períodos hábiles para el ejercicio de la caza;

- https://www.boe.es/boe/dias/2020/11/20/pdfs/BOE-A-2020-14645.pdf

\section{Otras fuentes}

- https://amigosdellobodesierramorena.blogspot.com/ 
- https://www.asajacyl.com/

- http://awsassets.wwf.es/downloads/veneno_en_espana_2016.pdf (El veneno en España. Evolución del envenenamiento de fauna silvestre (1992-2013), publicado por Seo/BirdLife y WWW/Adena, 2016)

- https://www.cbd.int/

- https://www.cbd.int/doc/legal/cbd-es.pdf (Convenio de Naciones Unidas, 1992)

- https://www.cites.org/eng

- http://www.derechoanimal.info/es

- https://www.eurogroupforanimals.org/

- https://www.eurolargecarnivores.eu/es/

- https://www.fapas.es/

- https://www.fecaza.com/

- https://www.fecaza.com/caza/requisitos-del-cazador

- http://fedecazacyl.es/

- https://www.iucn.org/es

- https://www.iucnredlist.org/es/

- https://ec.europa.eu/environment/nature/conservation/species/carnivores/coexistence platform.htm

- https://ec.europa.eu/environment/nature/natura2000/index_en.htm

- http://www.juntadeandalucia.es/medioambiente/portal_web/web/temas_ambientales/programas_eu ropeos y relac internac/programas europeos/life/proyectos ejecucion/SOUTHERN\%20WOLVE S/LIFE\%20Southern\%20Wolwes/Ficha\%20proyecto\%20web.pdf (Life Southern Wolves. The Wolf of Andalusia: Changing attitudes)

- https://www.justiciaydefensaanimal.es/

- https://lifelobo.es/

- https://loboiberico.com/ascel/

- https://www.loboiberico.org/pt

- http://lobomarley.org/

- https://www.miteco.gob.es/es/biodiversidad/temas/inventariosnacionales/censo_lobo_espana_2012_14pdf_tcm30-197304.pdf [Censo 2012-2014 del lobo ibérico (Canis lupus, Linnaeus, 1758) en España]

- https://pacma.es/

- https://www.signatus.org/

- https://www.youtube.com/embed/-i1vUK2UUxY (vid. "En tierra de todos")

- https://www.wwf.es/?37000/12-propuestas-para-la-conservacin-del-lobo

- Revista JARA Y SEDAL, $n^{\circ} 222$, junio, (Madrid 2020)

- Revista QUERCUS, nº 413, julio, (Madrid 2020)

- Revista QUERCUS, $n^{\circ}$ 423, mayo, (Madrid 2021) 